COPEPOD PARASITES OF FRESH-WATER FISHES AND THEIR ECONOMIC RELATIONS TO MUSSEL GLOCHIDIA : : : : : : : : By Charles Branch Wilson

From BULIETIN OF THE BUREAU OF FISHERIES, Volume XXXIV, 1914 Document No. $824:: \quad: \quad: \quad: \quad: \quad: \quad: \quad: \quad: \quad: \quad$ Issued June 28,1916

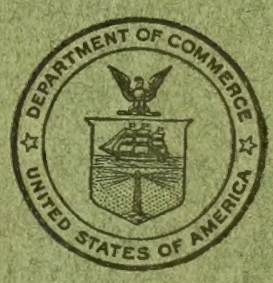

WASHMVTON : : : : : : GOVERNMENT PRINTING OFFICE : : : : : : : : $: 1916$ 





\section{COPEPOD PARASITES OF FRESH-WATER FISHES}

AND THEIR ECONOMIC RELATIONS TO MUSSEL GLOCHIDIA : : : : : : : : By Charles Branch Wilson

From BULLETIN OF THE BUREAU OF FISHERIES, Volume XXXIV, I9I4 Document No. $824: \quad: \quad: \quad: \quad: \quad: \quad: \quad: \quad: \quad$ : Issued June 28, I9I6

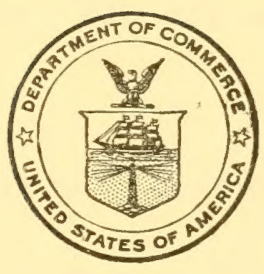




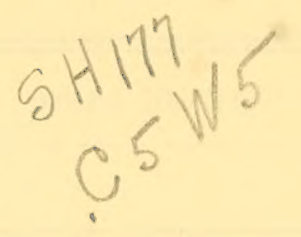

ADDITIONAL COPIES

OF THIS PUBLICATION MAY BE PROCURED FROM THE SUPERINTENDENT OF DOCUMENTS GOVERNMENT PRINTING OFFICE WASHINGTON, D. C.

AT

25 CENTS PER COPY

D. of D.

JUL 121916 
COPEPOD PARASITES OF FRESH-WATER FISHES AND THEIR ECONOMIC RELATIONS TO MUSSEL GLOCHIDIA

\author{
$*$ \\ By Charles Branch Wilson
}

State Normal School, Westfield, Massachusetts

Contribution from the United States Fisheries Biological Station, Fairport, Iowa 



\title{
COPEPOD PARASITES OF FRESH-WATER FISHES AND THEIR ECONOMIC RELATIONS TO MUSSEL GLOCHIDIA.
}

\author{
BY CHARLES BRANCH WILSON, \\ State Normal School, Westfield, Massachusetts. \\ * \\ Contribution from the United States Fisheries Biological Station, Fairport, Iowa. \\ \% \\ INTRODUCTION.
}

Under an appointment by the Commissioner of Fisheries, during the summer of I9I4, at the United States Fisheries biological station at Fairport, Iowa, an extended examination was made of the parasitic copepods which infest our fresh-water fishes in the Mississippi River and its tributaries and of the mussel glochidia which are also parasitic upon fish during their term of metamorphosis. Several of the early American naturalists became interested in the copepods found upon fresh-water fish, and many new species were described. This was especially true of Le Sueur and Dana, and singu larly enough the Danish investigator, Kr $\varnothing$ yer, also obtained a number of American species from fish sent to the Copenhagen Museum. But in every instance the species described were isolated, they were sometimes founded upon single specimens, and many of them have never been seen since their original discovery.

Prof. S. I. Smith published in the Report of the United States Commissioner of Fish and Fisheries for $1872-73$ a list of the crustacean parasites of the fresh-water fishes of the United States (p. 66r-665). This list included two argulids, one caligid, one ergasilid, six lernæopods, three of which were new to science, and two lernæans, I2 species in all. With true scientific foresight, Prof. Smith stated that the few species he enumerated were "doubtless only a small fraction of those which really prey upon our common fishes," and that his principal object was to "call attention to the subject and furnish a basis for future investigation" (p. 66I). But his suggestion did not meet with the response it deserved and beyond the investigations of Smith himself, Packard, Kellicott, Wright, Fasten, and a few others, all widely scattered, no attempt has been made to increase the list up to the time of the present investigation.

About I 895 Mr. R. R. Gurley, at that time in the employ of the United States Bureau of Fisheries, gathered together all the available data with reference to the copepods parasitic upon fresh-water fishes, translating the descriptions given by Krøyer and other foreign investigators and identifying both hosts and parasites amongst the material in possession of the Bureau. He made no attempt to establish new species, but only to bring together all that had been previously described, and he accumulated 
a manuscript of about I5O pages, which was subsequently turned over to the present author. This has proved of great value on other occasions as well as the present, and Gurley's original identifications and additions to the work of previous authors are acknowledged in the following pages.

The specimens and other material were derived from several sources. First, the work of the biological station involves the handling of large numbers of fish, and several of the regular staff, notably Mr. H. W. Clark, Mr. T. Surber, and Dr. A. D. Howard, have saved such parasitic copepods as they found while examining the gills for glochidia. These were generously turned over to the present author, who had also accumulated a large number of specimens during the surveys of the mussel fauna of various regions of the United States under the auspices of the Bureau of Fisheries.

These collections were augmented during the present investigations by a careful examination of all the preserved gills of fish in the possession of the biological station, of the gills of live fish caught by the regular seining crew or brought to the station for glochidial infection, and of a large number of dead fish caught by local fishermen.

In these different ways, and including chiefly the waters of the Mississippi Valley, the original list has been increased to 46 species, Io of which are new to science; I of Kr $\phi y e r$ 's and I of Le Sueur's species have been rediscovered, and there have been added the larvæ of 4 other species in various stages of development.

During the investigation it early became apparent that certain economic relations existed between the copepod parasites and the mussel glochidia, which are also parasitic on fish. Although the broad fact that parasitized fish do not take or hold glochidia as well as the nonparasitized ones was observed early in the work at the station, nevertheless the existence of particular mutual relations between copepods and glochidia had never been suspected. Of all the authors above mentioned Fasten is the only one who has ever treated the copepods from an economic standpoint, and his excellent papers deal chiefly with the artificial propagation of a single species. It is at once evident, however, that the interrelations between the fish and the two kinds of parasites must exert considerable influence upon the artificial propagation of mussels, as well as upon an intelligent study of the parasitism of the copepods. Accordingly these economical discussions are placed first in the present paper, and the description of the species is left until the last.

\section{RELATIONS BETWEEN THE COPEPODS AND THEIR HOSTS.}

As has elsewhere been stated, both by the present author (Proceedings of United States National Museum, vol. 25, p. 654) and by other investigators, it is not probable that the copepod parasites of fresh-water fishes become under natural conditions a serious menace to the life of their host. But it must be remembered that their presence upon the fish is always injurious to the latter and can never be beneficial nor even indifferent.

I. There is a notion prevalent in certain quarters that a limited amount of dirt and vermin is wholesome rather than harmful. It is needless to say that this is erroneous, and that there is no truth also in the idea that a few of these creatures do their host no real harm, but that a considerable number must be present in order to become really injurious. Even a single parasite withdraws from its host enough blood for its own 
sustenance. That amount may be small, but it is nevertheless a loss, and it weakens the fish's vitality by just so much. 'The simple fact that a sufficient number of parasites can weaken or even kill a fish is enough to prove that each one does his share toward that end and is therefore harmful. And here in the Mississippi Valley there are other considerations which tend to greatly increase this influence of parasitism.

2. The parasites, especially the ergasilids, are more numerous upon young fish; one can scarcely examine a young crappie or calico bass 3 to 5 inches in length without finding it infested with Ergasilus cxrulcus, its particular parasite, and the same may be said of the hosts of the other ergasilids. It is not quite as noticeable in the case of the argulids and lernæopods, although eren here the smaller fish are the ones most frequently infested. These young fish are like the young of all animals, including even man. They are growing rapidly; they need all the vital energy they can produce to carry on this growth successfully, and hence they are more susceptible to the injurious effects of parasitism than the matured adult. We thus find a maximum of numbers of parasites at that very stage of development when there is a minimum of resistance on the part of the host, and this greatly increases the influence of the former upon the latter.

3. Again, the parasites are more numerous in the slews and cut-offs (so-called lakes) than in the main river. This is due partly to the absence of a current, thereby enabling the parasite larva to swim about freely, and partly to the crowding together of the parasites and fish, which materially aids the former in their search for the latter; but in these shut-off bodies of water the conditions are not as favorable to the fish as in the open river, especially late in the season. There is not as much food, the water is not as well aerated, and there is a keener struggle for existence. Furthermore, in these slews the young fish far outnumber the older ones; these are the very places to which they resort to escape their enemies. Scarcely a fish can be found in these "lakes" and slews which is free from parasites, and towing reveals the presence of large numbers of parasite larve swimming about in search of a host. Thus the parasites attack their hosts not only at the stage of development when they are most susceptible, but also in the places and under the conditions when they are least able to withstand the attack, again greatly augmenting the influence of parasitism.

4. With the time, the place, and the conditions thus favorable to the parasites, the latter respond quickly and show an abnormal increase in development. A far greater number reach maturity than under less favorable conditions; these in turn breed, and the number of larva is increased a hundredfold; a considerable percentage find hosts, thus crowding the gills of the young and already weakened fish. In this way parasites that are comparatively harmless under ordinary conditions may, and of ten do, become a serious menace to the life of the fish.

These considerations are enough to show that the presence of even a few parasites is not a matter of indifference. Fortunately, under ordinary conditions the parasite has an even harder struggle for existence than its host. In this struggle the different kinds of parasites are affected differently, while the ultimate issue is the same for them all.

The ergasilids swim about freely until they reach maturity. The male never becomes a parasite, but completes its life as a free swimmer, while the female seeks a particular host. During this comparatively long free-swimming period both sexes have to 
contend with many enemies. They are then a part of the plankton and as such have to contribute their share foward the support of all the varied life which feeds upon the plankton. There are many animals which eat copepods and none of them are at all particular as to the species. These free-swimming ergasilids are fully as toothsome as other kinds and are as often eaten. The male never escapes this clanger, but the female cloes when she has once fastened to the gills of a fish. It sometimes happens, however, that when the female is ready to fasten to a fish all the fishes suitable for hosts have left ile vicinity. Under such conditions the female parasite must die unless she can swim far enough to find a host.

The argulids swim about freely, even after reaching maturity, especially the males. During this swimming they also become part of the plankton and share in its dangers and vicissitudes. Being external parasites, they are not compelled to find a particular host, for they can remain temporarily upon almost any fish until their true host is found. They are thus much less susceptible to the dangers of the plankton than the ergasilids, and when they have once reached maturity they are thenceforth free from such dangers. Their much larger size also operates in their favor, for they are too bulky to be caught by most of the creatures which eat ordinary copepods.

The lernæopods have but a very short free-swimming period, a few hours at the most, and during that time they, too, are subject to the dangers of the plankton. They must not only survive these dangers but they must also find a particular host within this brief period or they perish; and the same disaster often overtakes them that haplens to the ergasilids, namely, when they are ready to attach themselves there are no suitable hosts available.

The lernæids also become a part of the free-swimming plankton at two separate periods in their derelopment. First during the nauplius and metanauplius stages, when they are indistinguishable from all other copepods in the same stages, so far as the dangers of the plankton are concerned. Then they spend the copepodid stages as parasites upon the gills of some fish, apparently any that happens to be available. On learing this intermediate host they again enter the plankton and swim about freely while a union of the sexes takes place. The male develops no farther, but the female must seek a permanent host, and this time it must be a particular species of fish. During this latter period, therefore, they are in the same condition as the lemxopods and often experience the same trouble, namely, when they are fully developed there are no suitable hosts available.

It follows that the parasites are ordinarily held in check by these means, and if they are to hecone anything of a menace to the fish there must be peculiar conditions favorable to them and unfavorable to their hosts. The custom practiced by the biological station of seining the fish out of the "lakes" and slews that are likely to go dry and putting them back into the main river is the best thing that could be done to get rid of the frardsites. We have just seen that the latter breed rapidly under the conditions obtaining in the slew and that everything works together in their favor. By removing the fish such breeding is at once stopped; all the parasite larva and adults left in the slew die, and the new conditions in the main river are such as to keep subsequent breeding within due bounds. 
RELATIONS BETWEEN THE COPEPODS AND THE GLOCHIDIA.

We have just discussed the relations between the fish and the copepods, but both copepods and glochidia infest our common fresh-water fishes. Consequently, in view of the efforts which are being put forth by the United States Bureau of Fisheries for the success of artificial mussel propagation it becomes imperative to know whether the habits of these two kinds of parasites are harmonious or antagonistic. Does the presence of copepods upon our common fishes influence in any way their susceptibility to infection by mussel glochidia? This problem can be most intelligently discussed in the form of a series of questions and answers.

I. Are the fish that serve as hosts for the copepods those which are naturally susceptible to infection by glochidia?

This question can be best answered by arranging in tabular form a list of the fishes with their glochidia and copepod parasites in parallel columns. 


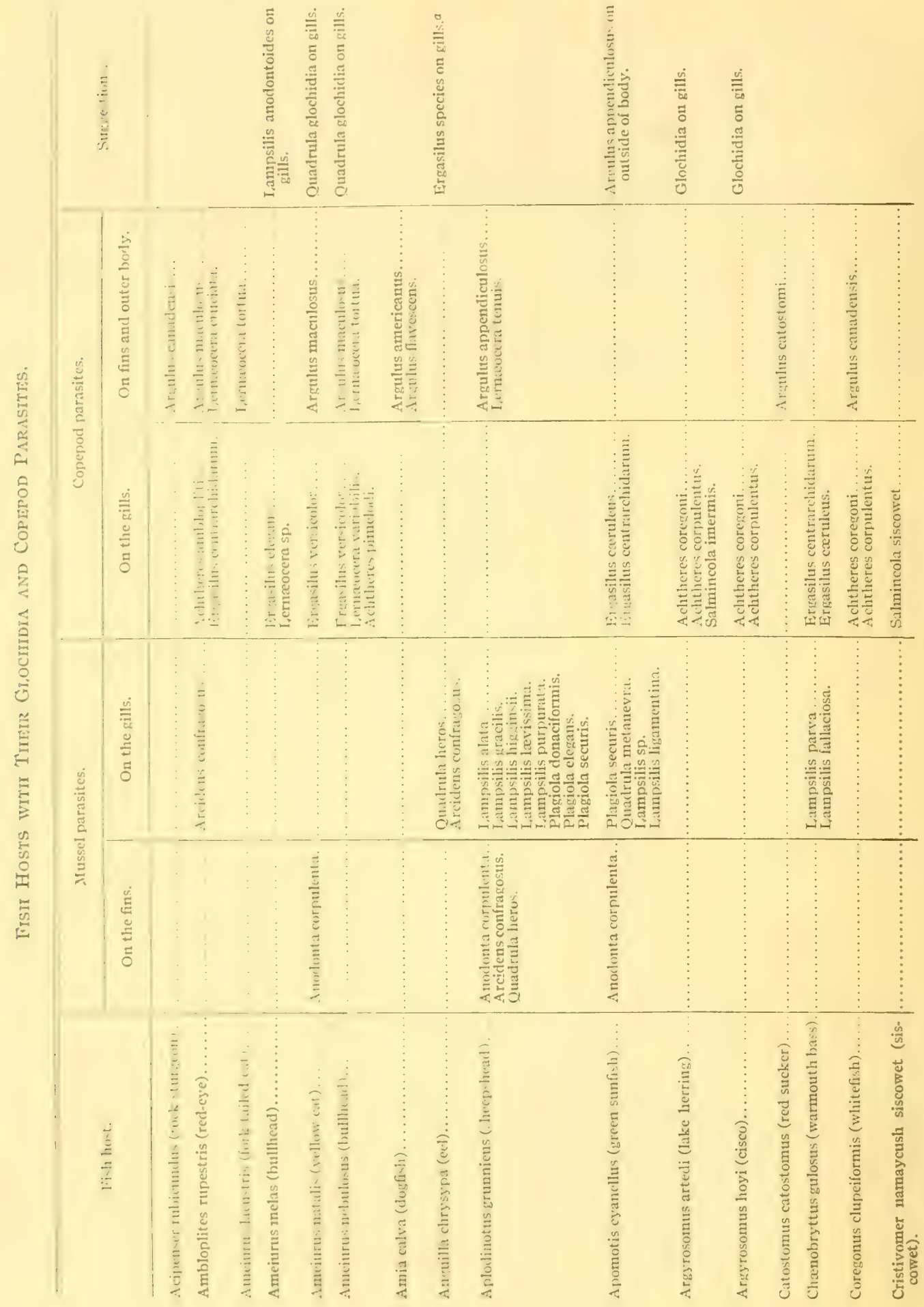


COPEPOD PARASITES AND MUSSEL GLOCHIDIA ON FRESH-WATER FISHES. 339

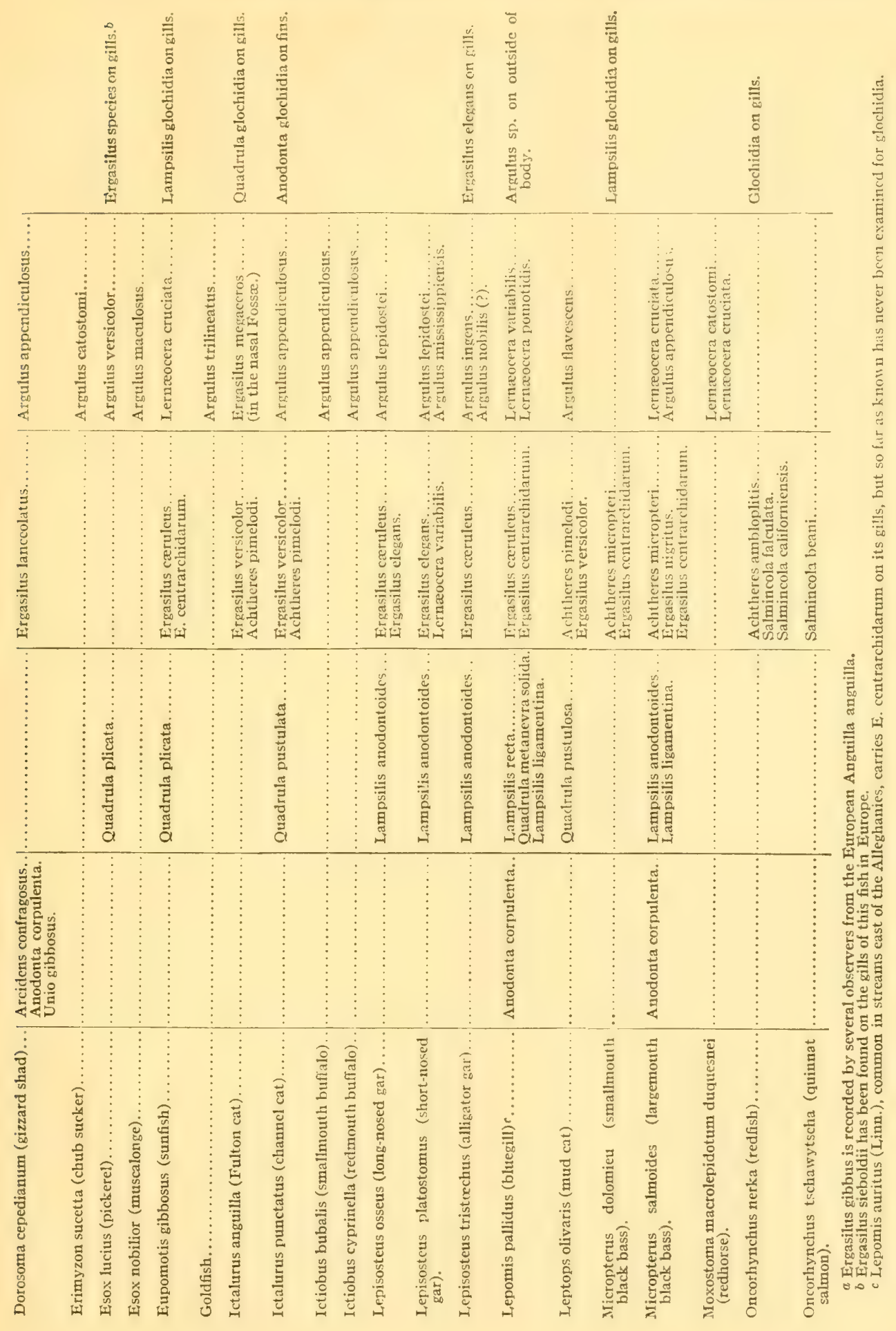




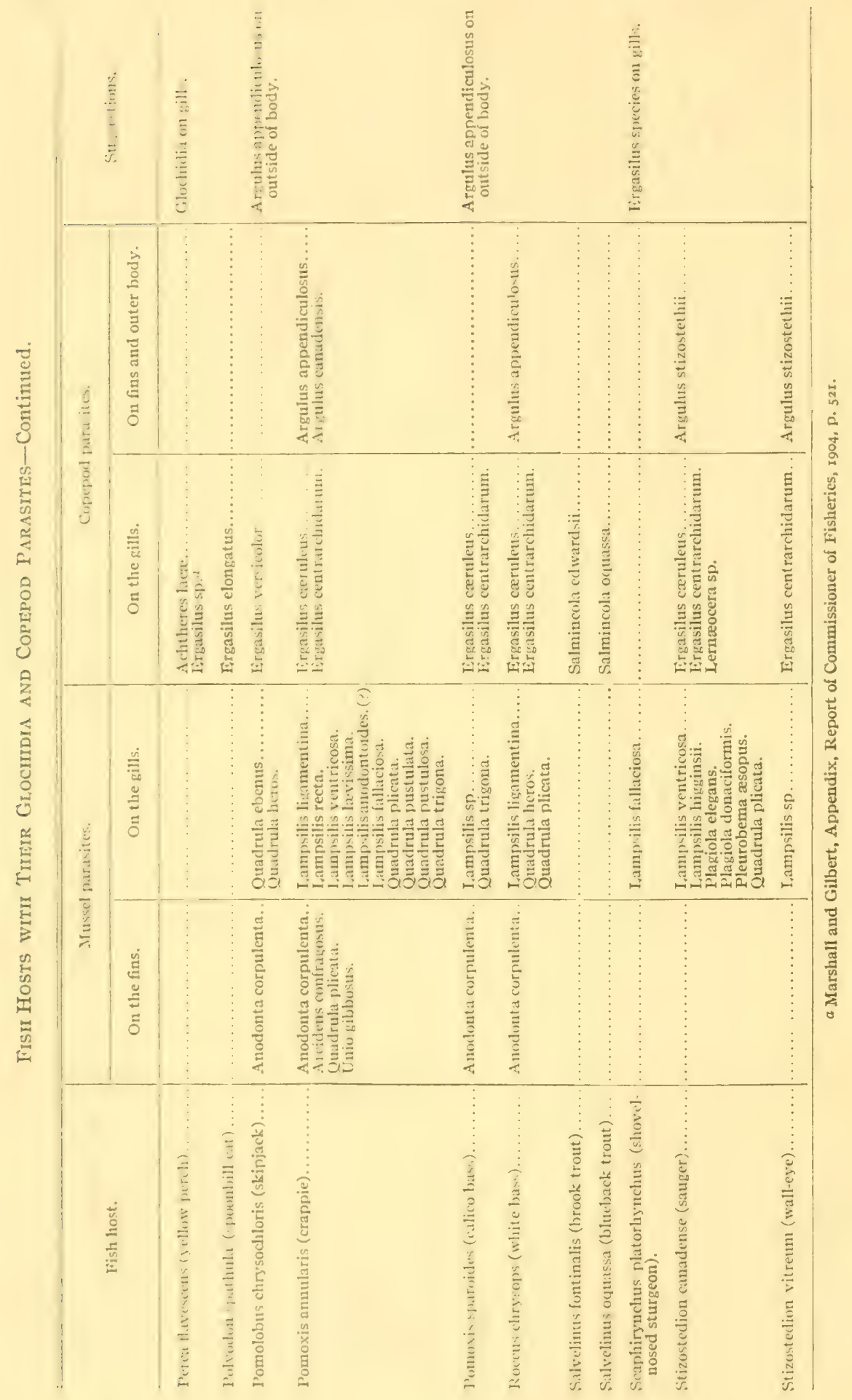


A careful reading of this table shows us:

I. The fish which carry the copepods are also those which serve as hosts for the glochidia.

There are a few exceptions on either side-some fish, like the eel and the shovelnosed sturgeon, which carry only glochidia, and others, like the dogfish and the bullhead, which carry only copepods. But these are simply the exceptions that prove the rule, and we inust also remember that not all the fishes in the list have been thoroughly examined for both copepods and glochidia. Future investigations are very likely to reduce these exceptions and possibly to eliminate them entirely. This is exactly what would be expected, for the temporary parasite, the glochidium, is not so very different in some respects from the permanent parasite, the copepod. The conditions which are favorable to the one would favor the other also, and the conditions which are adverse to the one would be adverse to the other. Hence we may go a step further and affirm:

2. The species of fish which are ordinarily free from copepod parasites do not furnish conditions favorable to infection by glochidia.

The numerous species of buffalofish, carp, suckers, lampreys, minnows, shiners, dace, chubs, and darters are excellent examples. The above table includes all the freshwater fish at present known to serve as hosts for either copepods or glochidia, and practically none of these fish appear in either list. Nor are they likely to appear in any numbers, for these fish have been as thoroughly examined as any others, but nothing has been found upon them. Lefevre and Curtis mention some of the mechanical factors which tend to render a fish immune to infection by glochidia, such as the smallness of the gill openings, the rapidity of the fin movements, and the texture of the gills. They mention as the most striking instances of immunity the German carp, certain minnows, and the darters, three of the above-named fish. By means of artificial infection they exposed these fish to glochidia, a few of which fastened upon their gills and fins; but these were quickly sloughed off, and none could be carried through the parasitic period. "The disappearance of the hookless glochidia of Lampsilis from both gills and fins of the carp *** suggests rather that there may be some reaction of the host's tissues comparable to the processes which confer immunity against parasitic bacteria in higher vertebrates." (Lefevre and Curtis, Bulletin Bureau of Fisheries, vol. xxx, p. I63.)

We can readily understand how an immunity of this character could operate against the parasitic copepods as well as against the glochidia. Extensive examination in the future may, and probably will, reveal straggling copepods and glochidia, but in such small numbers that they must be regarded as accidental infections. ${ }^{a}$

3. The fish which make the best copepod hosts are also those which are naturally infected with the greatest number and variety of glochidia.

A fish's efficiency as a host may be measured either by the number of any single parasite it harbors, or by the variety of species. In the copepod parasites these two criteria are usually separated and must be considered independently. In the mussel glochidia they are nearly always united, and may therefore be treated conjointly.

Keeping these facts in view, we notice first that the crappie, Pomoxis annularis, stands at the head of both lists. It serves as the host of at least 13 species of mussel glochidia, and yields often as many as 500 or 800 specimens of some particular species

a Argulus foliaceus and Ergasilus sieboldii have been found once or twice on the carp (Cyprinus carpio) in Europe, while Lernoocera pectoralis was reported by Kellicott from the red-fin shiner (Notropis cornutus) in the Shiawassee River, Mich. 
like L. ligamentina or $L$. ventricosa. When artificially infected, each crappie will take from 1,000 to 2,000 glochidia and sometimes even more.

Turning now to the copepods, we find that while it carries on its gills only two species, it is, nevertheless, the worst infected fish in the Mississippi River so far as numbers are concerned. Hardly a crappic examined during the summer season failed to yield specimens of one or both copeporls, and irecinently the number from a single fish reached into the hundreds and sometimes came close to a thousand. The difference in size between the glochidia and copepods make these numbers closely correspond, and the limit in both instances is apparently determined only by the actual living space on the gills.

The second fish on the list is the sheepshead, Aplodinotus granniens, which serves as a host for II species of mussels, and upon the gills of which the number of individual

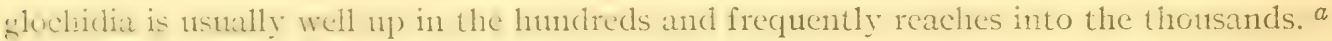
This is an apparent exception to the rule, for while there is an external Argulus parasite to correspond with the few fin glochidia, a careful examination of all the sheepshead gills that were available (about 500) failed to reveal a single copepod; but there are certain facts which profoundly influence our judgment in the present instance.

First, and of the greatest importance, this fish habitually feeds upon thin-shelled mussels, crushing the shells with its puwerful pharyngeal jaws. Whenever the shell of a gravid mussel is crushed in this way the gills of the fish necessarily become iniected with the glochidia which are set free. L. lavissima and $P$. donaciformis are the ones whose glochidia are found in greatest numbers, and these as well as most of the others have papery shells. This method of infection is quite different from that in the crappie and other fish and comes close to being artificial. Furthermore, such infection is practically constant, in fact as constant as the feeding of the fish, and thus the gills are lept loaded with glochidia all the time. The presence of these glochidia prohibits that of the copepods, as will be shown later. The glochidia of the thick-shelled mussels like $Q$. heros are obtained in the usual way and are much fewer in number.

Again we find upon the sheepshead's gills, in addition to the mussel glochidia a trematode ectoparasite, which exists in as great abundance as the copepods upon the gills of the crappic. The presence of these worms may still further explain the absence of copepods.

After the sheepshead comes the sauger with six species of glochidia, the green sunfish with five, the bluegill and white bass with four each, and the gizzard shad, the largemouth black bass, the skipjack, and the calico bass with three each. Of these the hluegill, the white bass, and the calico bass are each infested with the same two species of Ergasilus as the crappie, in smaller numbers but still to a considerable degree. The largemouth black bass carries a still smaller number of individual copepods but compensates for it by being the host of five different species. The green sunfish, the gizzard shad, and the skipjack have but a single copepod parasite on their gills, but they are also really the host of but a single kind of glochidium, the others being found in such small numbers that they can be regarded only as aceidental infections. Having thus determined that the same fish serve as hosts for both copepods and glochidia, a second question naturally arises:

a On the gills of one fish of this species 5,200 glochidia of $\psi$. donaciformis were found, and upon another fish ro, 400 of the same slochidia. 
II. Is there any fellowship between the different species of the two kinds of parasites? Do we find certain species of glochidia associated with the same copepod in a majority of instances?

This question can also be answered by reference to the table (p. 338), from which we deduce the following:

I. Of the external-fin glochidia Anodonta corpulenta is by far the most widely distributed and is always accompanied by an external Argulus parasite, usually A. appendiculosus. The green sunfish, the calico bass, and the skipjack are apparent exceptions; Anodonta glochidia have been found upon them but no Argulus copepod. It must be remembered, however, that the glochidia are fastened in the fins and remain there no matter how long the fish may have been kept or how much it may have been handled. On the other hand, the copepod merely clings to the outside surface of the fish and is easily brushed off when alive and practically always falls off when dead. Only a few of these fish have been examined under conditions favorable for finding the copepods, while the conditions are always favorable for finding glochidia.

Such being the case, it seems reasonable to expect that an Argulus parasite will be found upon the three fish just mentioned as the result of future examination; but the argument ought to work equally well in the opposite direction, and hence we may look for the future discovery of the glochidia of $A$. corpulenta upon the channel cat, its copepod fellow having been already found.

2. The glochidia found upon the gills of fish may be divided into the two great groups of Lampsilis species and Quadrula species. Accompanying the former we find Ergasilus cornleus in every instance, except upon the largemouth black bass, where it is replaced by Ergasilus nigritus, one of the new species. Accompanying the Quadrulas we find Ergasilus versicolor upon the catfishes and the skipjack and Ergasilus centrarchidarum upon the Centrarchidæ. In this instance the copepods and glochidia are equally well protected, and the only hindrance to their discovery is the lack of fish specimens. Some species of fish are always scarce, while others that may be ordinarily plentiful may be scarce at just the time when they are likely to become infested with the copepods or the glochidia. Hence, while one of the parasites might be well known upon the fish, the other might have escaped notice.

Apparently something of this sort has happened to a few of the catfishes and Centrarchidæ; copepods have been found upon them repeatedly, but thus far no mussel glochidia have been discovered. It would seem reasonable, however, to expect them, and some species of Quadrula will probably be found in the future upon the yellow cat, the bullhead, and the Fulton cat, while some species of Lampsilis will be found upon the common sunfish, Eupomotis gibbosus, the warmouth bass, and the smallmouth black bass. ${ }^{a}$

In connection with the association between E. centrarchidarum and Quadrula glochidia the following may be suggested:

(a) E. centrarchidarum is found on the gills of the largemouth black bass, but it is accompanied by $E$. nigritus, one of the new species which evidently takes the place on this host of E. cceruleus, the regular associate of Lampsilis species. The presence of centrarchidarum, therefore, is not to be interpreted as indicating that it is here excep-

\footnotetext{
a Since the writing of this paper two species of Lampsilis glochidia have been discovered upon the gills of the warmouth bass and have been inserted in the table on page 338 .

$16825^{\circ}-16-2$
} 
tionally associated with Lampritis species but, rather, that Quadrula glochidia will be found in the futwe upon this fish as they have been upon so many of the sunfishes and basses other than the largemouth.

(b) Upon the sunfishes it is worth noticing that the two copepods caruleus and contrivhilumbocur together, and we should expect such fish to become the natural hosts of both Lampsilis and Quadrula glochidia. Two of them, the bluegill and the frecen sminfish. have already yielded both kinds of glochidia, and it would seem probable that future investigution will find both kinds upon the other sunfish where now there is but a single kind.

(c) E. centrarchidanm is found upon the gills of the wall-eye, which have thus far vichlul only Lampsitis glochidia; but upon the sauger, another fish of the same genus as the wall-eye, both linds of copepods and both kinds of glochidia appear. Furthermore, both fishes vield the same species of Argulus, so that it does not seem presumptive to suppose that the second species of Eirgasilus and Quadrula glochidia will eventually be found upon the wall-eye, as they have already been upon the sauger.

3. There is a single well-marked instance of individual association between a glochiclium and a copepod. Lampsilis anodontoides, whose glochiclia are practically confined to the gars, is found to be accompanied by a peculiar copepod, Ergasilus clegans, mother new species, which differs markedly from the others of its genus in the fact that the female remains free swimming for a much longer period. Indeed, it seems probable that they leave the fish's gills after having fastened to them and swim about freely. There are two other new species, Ergasilus lanceolatus from the gizzard shad and $E$. clongatus from the spoonbill cat, which are fully as peculiar as E. elegans and which may well be the copepod half of other individual associations whose glochidial half has not yet appeared. Furthermore, we may look for E. clcgans upon the alligator gar, whose gills have already yielded specimens of Lampsilis anodontoides.

4. It has long been known that certain species of copepods are confined to particular hosts and are not found upon any others. The table furnishes us several well-marked examples of this: Argulus mississippiensis and $A$. ingens are each found upon a single host, and although the two hosts are gars and very closely related to each other the copepods are distinct species. Again, the two species of Ergasilus just mentioned, namely, lanccolatus and clongatus, are each restricted to a single kind of fish and are not likely to be found elsewhere. The same is true of Ergasilus megaceros and of Salmincola oquassa and $S$. edwardsii; in fact, a good proportion of copepod parasites of both freshwater and salt-water fish show such restrictions.

When we look at the glochidia we find that there are fully as many of them confined to a single host. Lampsilis alata, gracilis, and purpurata, and Quadrula solida, ebcnus, and trigona are good examples. Probably further investigations will modify many of these as well as of the copepods, but it is equally probable that some of them will prove to be always solitary. In the case of the glochidia we are not compelled to wait for natural infections, for we can subject a fish to the glochidia of many mussels and determine experimentally whether or not it will make a suitable host for them. In fact, this has been done by Dr. A. D. Howard, who, in the Bureau of Fisheries document no. $80 \mathrm{r}$, calls attention on page 36 to what he calls "Restricted infection," which he has demonstrated by actual experinent in the case of Quadrula pustulosa upon the channel cat. 
Nothing of this sort can be tried with the copepods, since we can not supply larvæ in the right stages of development as we can glochidia. But although our knowledge of both kinds of parasites is rather limited as yet, enough data have been accumulated to show that the two kinds of parasites behave very similarly in regard to their hosts. There is thus a decided similarity between them when each is found by itself upon some suitable host.

III. Does the actual presence of copepods on a fish's gills exert any influence upon its susceptibility to infection by glochidia?

In other words, granting that the same fish do serve as hosts for both glochidia and copepods, are the conditions favorable for both at the same time? This is manifestly something which can not be watched under natural conditions, and the only way to answer the question is by artificial infection experiments. Accordingly a hundred crappies, Pomoxis anmularis, of nearly uniform size (5 to 6 inches long), which had been caught and brought to the station for artificial infection, were carefully examined and 25 were found to be infested with Ergasilus caruleus, while the other 75 were free from them. The entire hundred were then infected in the usual manner and under exactly the same conditions with the glochidia of the black sand-shell, Lampsilis recta. After infection the 25 parasitized fish were killed, their gills were removed, and the number of copepods and glochidia on each was counted with the following results:

\begin{tabular}{|r|r|r|r|r|r|}
\hline Fish. & Glochidia. & Copcpods. & Fish. & Glochidia. & Copenods. \\
\hline 1 & 0 & 350 & 14 & 102 & 87 \\
2 & 46 & 150 & 15 & 7 & 393 \\
3 & 176 & 121 & 16 & 190 & 36 \\
4 & 226 & 140 & 17 & 63 & 310 \\
5 & 104 & 78 & 18 & 495 & 8 \\
6 & 337 & 7 & 19 & 40 & 196 \\
7 & 47 & 253 & 20 & 80 & 112 \\
8 & 38 & 218 & 21 & 16 & 372 \\
9 & 169 & 142 & 22 & 395 & 10 \\
10 & 257 & 44 & 23 & 9 & 403 \\
11 & 301 & 63 & 24 & 11 & 396 \\
12 & 372 & 30 & 25 & 143 & 134 \\
13 & 250 & 31 & & & \\
\hline
\end{tabular}

The average number of glochidia upon each of the nonparasitized fish was between $\mathrm{I}, \mathrm{OOO}$ and I,200. By comparing this with the numbers given in the table we deduce the following:

I. The presence of even a small number of copepods upon the gills of a fish reduces its susceptibility to infection by glochidia to one-third or one-fourth of what it would be if no copepods were present.

Even the gills that contained io copepods or less showed the presence of only a few hundred glochidia instead of the thousand or more upon a nonparasitized fish. Such a marked reduction can not be explained by the mere presence of the copepods; they do not occupy enough of the gills to exert any crowding influence, neither are they ever found attached to the tips of the filaments where the glochidia mostly congregate. Manifestly there is room enough for both kinds of parasites without serious crowding; gills that will accommodate 1,200 glochidia with no apparent injury to the fish can certainly find room for more than 400 when only Io copepods are present.

Lefevre and Curtis say that the stimulus which causes the glochidium to close and thus to fasten itself to the fish is purely a mechanical one (Bulletin Bureau of Fisheries, 
vol. xxviri, pt. I, p. 622). Here again the mere presence of a few copepods upon the gills a is fish could have no effect upon such a stimulus. The respiratory movements of the fish may have considerable to do with it; the crappie's respiration is not very vigorous even at its best, and this is especially true of small fish (Lefevre and Curtis, Journal Experimental Zoology, vol. 9, p. I03).

The irritation due to the presence of parasitic copepods may still further reduce these movements and thus prevent infection by glochidia; but if this were the only cause Io copepods could hardly produce so large an effect. It would seem as if there must be something further, either chemical or physiological in its action, in order to accomplish the known results. It will not be very easy to prove what this is, but meanwhile the facts remain unaltered that in some way the presence of a very few copepods greatly reduces the fish's susceptibility to infection by glochidia.

2. As the number of copepods upon a fish's gills increases its susceptibility to infection by glochidia diminishes. Naturally a limit is soon reached beyond which the susceptibility has diminished so much that practically there can be no infection at all; this limit for small crappies is about 200 copepods. If more than this number is present, the glochidia are rery scattering and are ustally below 50 in number. The copepods often increase to 500 , and in such instances there are no glochidia, or, if any, their number is expressed by a single digit.

Certain conclusions naturally follow from these facts. The first is that it is obvionily disadvantageous to attempt to infect with glochidia fish that are already carrying copepods. A few glochidia will always stick to their gills, but not in sufficient numbers to repay the labor expended. Since the large fish are relatively freer from copepods than the smaller ones, it follows that they make the better hosts. Not only are their gills lirger and thus capable of carrying more glochidia, but the latter will fasten to them more readily because of the comparative absence of copepods.

Again, the fish from the main river, whatever their size, make better hosts than those from the slews and "lakes," because they, too, are freer from copepods. This is especially true at those times when the water is very low; during a long-continued drought it would be of little use to try infecting fish caught in such places because they would be so infested with other parasites that very few of the glochidia would fasten to them. The best thing to do with such fish would be to replace them in the main river and trust to taking them again after they had gotten rid of their copepods.

3. It is obviously a poor rule that does not work both ways, and we find that the presence of glochidia is as prohibitive to the copepods as are the latter to the former. This also is something that can not be watched under natural conditions; neither can it be proved by experiment, for we can not supply parasitic copepods as freely as we can glochidia; but it is abundantly sustained by a study of natural infections on the gills of fish taken in the river. There are in the possession of the biological station about $\mathrm{I}, \mathrm{ooO}$ vials of gills showing natural infection by various glochidia. These were all carefully examined for parasitic copepods under a dissecting microscope, and in not a single institice where the number of glochidia exceded $\left.z^{\circ}\right)$ was there even a single copepod present.

This mutual antagonism between the copepods and giochidia enables us to understand clearly why the sheepshead's gills are never infested with copepods. From the nature of the fish's foocl, as already explained, its gills are kept crowded with glochidia 
all the time, and thus the copepods are shut out. This leads to the conclusion that when a fish's gills are artificially infected with glochidia the fish is thereby rendered immune to the copepods. Artificial infection therefore, as regularly practiced at the biological station, not only does the fish no harm but is even positively beneficial.

And this suggests a possible safeguard or remedy for some fish hatcheries. It occasionally happens that parasitic copepods get to breeding in a hatchery in such numbers that they kill the fish. Judging from the cases thus far reported, this seems more likely to occur among trout than among other game fish. The European trout (Salmo fario Linnæus) is the natural host of Margaritana margaritifera, but our American trout have been examined very little for glochidia. However, if there is any virtue in the conclusions here drawn, the very fact that they are more susceptible than other fish to the copepod parasites indicates that they would make excellent hosts for glochidia. If this be so, an infection with glochidia would be harmless to the fish, but at the same time would render them immune to the copepods. At all events, the experiment is worth trying.

4. The breeding season of the copepods thus acquires especial economic importance with reference to mussel propagation. It is manifest that at the close of a breeding season, when the larval brood of copepods have sought and found their hosts, their numbers will be at a maximum. Consequently this would be the time least favorable to infection with glochidia. On the other hand, the early spring, before the copepods begin to breed, and the intervals between successive breeding periods, would be the most favorable to glochidial infection.

We are not yet sufficiently acquainted with either kind of parasite to be able to make a complete schedule of their times of breeding, but many interesting facts have been ascertained.

Lefevre and Curtis in the Bulletin of the Bureau of Fisheries, volume xxx, page I4I, divide mussels into two groups according to the length of the period of gravidity. Those having a long period of gravidity, among which Lampsilis species predominate, produce ripe glochidia during the fall and winter and spring months. Those having a short period of gravidity, among which Quadrula species predominate, produce ripe glochidia during the summer months. Turning now to the copepods, we find that the ergasilids and argulids have three breeding seasons in the year, the first at the end of May or the beginning of June, the second at the middle or latter part of July, and the third in the latter part of September. We do not yet know all the breeding seasons of the lernæids and lernæopods, but from the material here presented and that obtained from many other investigations it is certain that they also have a breeding scason during the middle or latter part of July, and it is probable that there are two other seasons corresponding to those just given.

Comparing the breeding of the copepods with that of the mussels, it will be seen that the winter or early spring is the best time for infection with Lampsitis glochidia, since the only copepods then on the fish's gills are such adults as have lasted through the winter. None of the Quadrula group produce glochidia early enough to be used for spring infection, and the best months for them would be July and September, just before the second and third copepod breeding seasons; and from what has already been said of the cumulative effects of unfavorable conditions during low water the month of July would ordinarily be preferable to September. 
In the paper already referred to Lefevre and Curtis call attention to the desirability of reducing the length of the parasitic period of the glochidium (p. I gr), which is inversely proportional to the temperature of the water. Whether the shortening of the parasitic period during the warm summer weather will compensate for the increase in the number of parasitic copepods is a question that can be decided only after careful experimentation. We now know, however, that the presence of these copepods and their periods of breeding are factors that must be given due consideration before the question can be solved.

\section{SYSTEMATIC.}

A complete descriptim, fully illustrated with appropriate figures, is given of all the species which are new to science. Of those which have been previously described only such notes are included as are of interest or furnish additional information. The larvæ of a few species were hatched out in the laboratory of the station, and they also are fully described and illustrated, since they add considerably to our previous knowledge of the species. Several parasites were obtained by H. Irroyer, a Danish zonlogist, from fish taken near New ()rleans and sent to the Royal Museum in Copenhagen. Most of these fish were such as come up (he Mississippi River from the Gulf of Mexico, and hence their parasites can not be included amongst the strictly fresh-water species; but they are included in the present list because they are likely to be found in that part of the river.

The parasites of fish in the Great Lakes, the Lake of the Woods in Canada, and of several isolated lakes are also cnumerated, since they are all fresh-water forms and really belong with the great fresh-water fauna of the interior of our continent. A few species have been included from west of the Rock Mountains and east of the Appalachians.

\section{THE ARGULIDE.}

Argulus canadensis, new species. (P1, Lx.)

Host and record of specimens.-Three fine females were obtained by T. Surber at Le Claire, Minn., from fish caught in the Lake of the Woods. Two were from a species of whitefish, Coregonus, while the third was from a rock sturgeon, Acipenser rubicundus. The better of the first two is made the type of the new species and has been given catalogue no. $4352 \dot{x}$, U. S. National Museum. The other has been given catalogue no. 43525 , U. S. National Museum, while the specimen from the sturgeon received catalogue no. $435^{26}$, U. S. National Museum.

Specific characters of the female.-Carapace elliptical, a little longer than wide, the posterior lobes broad, evenly rounded, and reaching to about the center of the third thorax segment, leaving the two posterior pairs of legs fully visible in dorsal view. Instead of projecting anteriorly the cephalic area is slightly reentrant, ovate, and relatively very small; posterior sinus one-third the length of the carapace, its width posteriorly equal to its length, but narrowed and squarely truncated anteriorly. The supporting rods in the lateral areas of the carapace are peculiarly arranged, meeting at a point far forward and giving the creature a sort of hunch-backed appearance. The respiratory areas are also peculiar, the outer one club-shaped, the large end anterior, while the handle of the club extends backward along the outer margin of the inner area, an arrangement wholly different from anything heretofore described. Abdomen a littie more than one-fourth the entire length, its width to its length as 5 to 8 ; anal sinus cut beyond the center, its sides parallel, lobes narrow-elongate and rather bluntly rounded, papillæ basal. Eyes large and so far forward as to almost touch the anterior margin, but widely separated; sucking disks also far forward and well separated, one-eighth the width of the carapace.

Antennx small and weakly armed, the terminal joints of the first pair not reaching beyond the lateral claw, the anterior claw minute and nearly straight; second antennæ slender, basal joint enlarged with a small spine on its posterior margin. A pair of large accessory spines behind the antennæ and close to the median line; another pair between the bases of the maxillipeds or slightly posterior to them. 
The supporting rods of the membranous border of the sucking disks are made up of an oblong basal joint and a series of 10 or I I plate-like disks, overlapping one another like shingles and diminishing in size distally, similar to those in Argulus megalops. The basal joint of the maxillipeds is mucl swollen, the basal plate does not quite reach the posterior margin, and is armed with three slender acuminate teeth; this plate has a rounded lobe outside of the teeth, which carries a short spine at its center. The ventral protuberance is large in area, oval in outline, and is put on diagonally, the small end filling out the rounded external lobe just mentioned; there are also spiny areas at the distal end of the basal and third joints, and over the whole surface of the second joint; there are two terminal claws and a fingerlike process outside of them.

Color (preserved material), carapace, abdomen, and the entire ventral surface a clear creamy white; dorsal surface of the thorax covered with rounded spots of a deep reddish purple, with a white streak through the center above the intestine; these spots extend forward beneath the carapace as far as the mouth; eyes and semen receptacles a lighter purple.

Total length, I2 mm.; carapace, $7.2 \mathrm{~mm}$. long, $7 \mathrm{~mm}$. wide; abdomen, $3.4 \mathrm{~mm}$. long, $2.2 \mathrm{~mm}$. wide. (canadensis, Canadian.)

Remarks. - This is a large and powerful parasite and is evidently our American representative of the European species coregoni. It would be interesting to ascertain whether they produce any such effect on the fish in the Lake of the Woods as is recorded for the fish of the lakes in Jemtland by Dr. Nystrom. (Proceedings U. S. National Museum, vol. 25, p. 725.)

That our species is distinct from coregoni is shown by the following differences. There are no flagella on any of the legs, while in coregoni they are full sized. The cephalic area is reentrant anteriorly instead of protuberant. The eyes almost touch the anterior margin and are rather small. There is no ovate papilla on either side of the opening of the oviduct, which Thorell makes one of the prominent characters of coregoni. The respiratory areas are very different, not only from coregoni but from every other known species of Argulus. This is evidently a northern species, since it has not been found upon any of the numerous species of Coregonus in the Great Lakes. The male is as yet unknown.

Argulus flavescens, new species. (P1. LXI, fig. 7-I2.)

Host and record of specimens.- Two females were obtained from the outside of the dogfish, Amia calva, caught in "Sunfish Lake," near Fairport, Iowa, August 8, I9I4. The better of the two is made the type of the new species and has received catalogue no. 47759 , U. S. National Museum; the other becomes a cotype with catalogue no. 47760 , U. S. National Museum. A third mutilated specimen was obtained from the gills of the mud cat, Leptops olivaris.

Specific characters of female.-Carapace elliptical, a little longer than wide, and evenly rounded; lateral sinuses scarcely perceptible; posterior sinus more than twice as long as wide, and two-fifths the length of the carapace, with nearly parallel sides; posterior lobes not reaching the abdomen, broad and plump; abdomen broadly ovate, as wide as long, and narrowed to a short neck where it joins the thorax; anal sinus about one-third the length of the abdomen, considerably enlarged at the base; anal papillæ spherical and basal.

Entire under surface of the body, including the abdomen, covered with small spines, pointing backwards; eyes small, placed well forward and some distance apart, facets minute; lateral ramifications of the stomach large and particularly prominent by reason of their color and lobed edges; respiratory areas made up of a small anterior, nearly circular portion, and a long posterior portion, which reaches nearly to the tip of the posterior lobes; sucking disks of medium size, placed well forward and close together. First antennx slender, the anterior claw rudimentary, the lateral claw curved into threequarters of a circle, the two terminal joints slender and reaching well beyond the tip of the claw. Second antennæ with swollen basal joint and three long terminal joints, abruptly reduced to one-third the width of the basal joint and sparsely armed with setæ; a small flattened spine on the basal joint of each antenna and an accessory pair of larger and sharper spines posterior to the second antennæ and close to the midline,

Basal plate of the maxillipeds small and narrow, with short, flattened, and bluntly rounded teeth; raised area a long and narrow oval; the four terminal joints each with a roughened area along the anterior and distal margins; last joint tipped with two minute claws and a fingerlike process. Swimming legs of the usual pattern, the posterior pair with a small lobe, which is not boot-shaped, but flares at both ends, 
and which does not reacli the margin of the abdomen. The supporting rods of the border of the sucking disks are made up of a basal rectangular section and from four to six barrel-shaped terminal sections, the distal one incomplete and shaped like the letter $\mathrm{J}$, with the stem convoluted.

Color, a pale jellowish white; the entire digestive canal, including the ramifications of the stomach, a rich creamy yellow, in strong contrast to the white background; eyes dark cinnamon brown; upper surface of the body covered with irregular spots of jet black, thickly sprinkled along the center and over the lateral ramifications of the stomach, but entirely lacking around the eyes and the anterolateral sinuses; semen receptacles yellow, surrounded by a black line.

Total length, $6 \mathrm{~mm}$; ; carapace, $4.35 \mathrm{~mm}$. long, $4.20 \mathrm{~mm}$. wide; abdomen I mm. long and wide.

(flavescens, yellowish, alluding to the digestive system).

Remarks.-This is a small and highly colored species and is apparently rather rare, since only the three specimens were found during the entire summer. It may be recognized at once by the prominent yellow lateril lobes of the stomach, the jet-black pigment spots on the dorsal surface, and the comparatively minute abdomen, with its tiny anal papillæ in the enlarged base of the anal sinus. It seems probable that the mud cat is the real host of this species and that the two specimens on the outside of the dogfish were only seeking temporary lodgment.

\section{Argulus mississippiensis, new species. (P1. LXI, fig. I3-I5; pl. Lxח, fig. 2I; pl. LxII.)}

Host and record of specimens. - Six males and six females were taken by the author from the shortnosed gar, Lepisosteus platostomus, at Fairport, lowa, July I7, I9I2. They have been given catalogue no. 4357 I, U. S. National Museum. One of the largest females has been selected as the type of the species and has received catalogue no. 43528, U. S. National Museum. This species is found upon the back of the gar's neck just above the dorsal aorta, and there is usually only one parasite on each fish.

Specific characters of female.-Carapace about three-fifths of an ellipse, its long diameter transverse; anterior sinuses narrow and deep; posterior sinuses one-quarter the length of the carapace, longer than wide, its sides approximately parallel; lateral lobes very broad, obliquely truncated posteriorly, not quite reaching the abdomen. Eyes comparatively minute and widely separated; respiratory areas placed obliquely at the extreme posterior end of each lobe, the outer area semilunar, its ends considerably enlarged and well rounded, the inner area about the same size as one of the sucking disks, inserted on the inner side of the outer area near its anterior end, but separated from it by a considerable interval. Abdomen elliptical, one-fourth longer than wide, and half as long as the carapace; posterior sinus narrowtriangular, not cut to the center; papille lateral, near the tips of the lobes; semen receptacles elliptical and close to the midline, their long diameters parallel with the axis of the abdomen.

Antennx small and stout; first pair with a medium-sized anterior claw and a long and stout lateral one, the terminal joints linear and not projecting beyond the tip of the lateral claw; second pair with a ventral protuberance on the basal joint just above the basal spine. Sucking disks small, only onefourtecnth the width of the carapace and widely separated; supporting rods slender and made up of a variable number of linear joints; no fringe on the margin. Maxillipeds also small but stout; basal plate projecting far behind the murerin of the basal joint and carrying a large lobe distal to the spines; the latter large and acuminate; ventral protuberance small and circular; a roughened plate on the third joint; terminal claws and papille minute. A pair of small accessory spines between the bases of these maxillipeds and another larger pair some distance behind the antennæ.

Each of the three posterior pairs of swimming legs carries a ventral lobe fringed with setæ on the basal joint; the lobes on the second and third legs are small, that on the fourth legs is much larger and projects beyond the lateral margin of the abdomen; the second joint of the endopod of the fourth legs also carries a small posterior lobe. There is a small anal papilla on either side of the opening of the oviduct.

Total length of figured specimen, I5 mm.; carapace, ro mm. long, I2 mm. wide; abdomen, 4.80 $\mathrm{mm}$. long, $3.75 \mathrm{~mm}$. wide.

Specific characters of male. -The general make-up of the male is similar to that of the female, the carapace lobes slightly overlapping the base of the abdomen; the testes are elliptical and not much larger than the semen receptacles in the female; the basal portion of the anal sinus, proximal to the papillæ, is a mere slit, whose sices are in contact or even overlap slightly. The secondary sexual apparatus is very complicated and closely resembles that of $A$. lepidostei. There is a roughened plate, armed 
with short spines, on the ventral surface of the basal joint of the second legs, at each end of which is a stiff fingerlike projection; the basal joint of the third legs carries a boot-shaped posterior lobe fringed with setæ; on the anterior margin, parallel with the axis of the joint, is a fingerlike process, covered with short spines, whose tip is turned forward just beyond the distal end of the joint; inside of this tip is the base of another long process, flattened anteroposteriorly and covered with short spines, which extends outward parallel with the second joint and overlaps the bases of the rami; on the posterior margin of this second joint, distal to the opening of the semen receptacle, is a small laminate process, fringed with long setæ; the musculature of these two basal joints is peculiar, as may be seen in fig. 27 . The peg on the fourth leg is double and stouter than in most species.

Total length of figured specimen, II mm.; carapace, $7.50 \mathrm{~mm}$. long, $9 \mathrm{~mm}$. wide; abdomen, 3.50 $\mathrm{mm}$. long, $2.50 \mathrm{~mm}$. wide.

Color of both sexes: Carapace, abdomen, and the ventral surface a light yellow, thickly sprinkled on the dorsal surface with small circular dots of light cinnamon brown. There are no spots on the thorax but the dorsal surface of the oviducts beneath the muscles is dark cinnamon brown, and it shows through very plainly; semen receptacles and testes dark orange yellow; eyes deep cinnamon brown.

(mississippiensis, of or belonging to the Mississippi River.)

Remarks.-With the exception of Argulus ingens, this is the largest species of the genus in America, and the measurements sometimes exceed those given above. For example, one female was found which measured $20 \mathrm{~mm}$. in length, while one of the males was ${ }_{5} \mathrm{~mm}$. long. In addition to its large size it presents many peculiarities of structure, the most noticeable being the double lobes on the fourth legs, the peculiar papillæ on the sides of the anal sinus, and the complicated respiratory areas. One of these parasites is as large as an ordinary copper penny and must drain the blood of its host quite severely. Fortunately for the fish, it is rare to find more than one parasite on a single fish; otherwise they would soon drain its blood. The present species completes the list and is the third found upon the gars, so that each gar now has its peculiar parasite, Argulus lepidoste $i$ upon the long-nosed gar, A. mississippiensis upon the short-nosed gar, and $A$. ingens upon the alligator gar.

Argulus lepidostei Kellicott. (Pl. LXI, fig. I6-I9; p1. LXIV; pl. LXV.)

Argulus, lepidostei, Kellicott, Bull. Buffalo Soc. Nat. Sci., vol. 3, p. 214, 1877; Wilson, Proc. U. S. Nat. Mus., vol. 25, p. 712, pl. 16.

Host and record of specimens.-Twenty males and twenty-one females were obtained from the shortnosed gar, Lepisosteus platostomus, at Fairport, June 23, I9I4, by Dr. A. D. Howard; they have been given catalogue no. 43543 , U. S. National Museum. One male and a female were taken from the longnosed gar, L. osseus, at Defiance, Ohio, by H. W. Clark; these have received catalogue no. 43522, U. S. National Museum. Most of these were found near the pectoral fins of their host, as was recorded of the original specimens by Prof. Kellicott.

Specific characters of female. - In addition to the descriptions given in the above references we may note the following: The respiratory areas are situated close to the posterior end of the lateral lobes; the outer and larger area is curved parallel with the margin of the carapace, its anterior end is narrowed, while the posterior end is thickened; the smaller and inner area is elliptical in outline and is inserted in the inner margin of the outer area near its anterior end (see fig. 29).

The ventral surface of the carapace is covered with orange-colored spines pointing backward. The color of the living female is a pale lemon yellow in young specimens, with only a few spots of cinnamon brown. These spots increase in size and number with advancing age and in full-grown adults become continuous along the dorsal surface of the free thorax. The eyes are deep violet brown, the semen receptacles a much paler yellowish brown.

Specific characters of male.-The accessory sexual apparatus of the male is complicated; the posterior flap on the second legs is roughened and armed with short spines; the peg on the fourth legs has an accessory peg distal to itself, which is solid and is not connected with the receptacle inside the first peg; the boot-shaped flap on this leg has no heel.

On the third legs a long slender and flattened process extends outward from the anterior margin of the ventral surface of the basal joint, parallel with the axis of the leg. Its tip is curved upward around the end of the second basal joint and often extends back toward the body on the dorsal surface. Above this process, on the anterior margin of the dorsal surface of the second joint, are two peculiar structures. 
The proximal one is a curved papilla, solid and thickly covered with short spines; the distal one is a hollow conical papilla, split along its dorsal surface, its free edge and much of its dorsal surface covered with short spines. In the posterior portion of this second basal joint is the usual semen receptacle within easy reach of the peg on the fourth legs (see fig. I7).

The color of the male is similar to that of the female but paler; the brown on the dorsal surface of the free thorax forms in adults a continuous line over the intestine; testes at first brownish yellow, then light reddish brown, and finally cinnamon brown. The ventral surface of both sexes is pale yellowish white without any pigment.

The newly hatched larva.-Two females of this species full of ripe eggs were captured July 3 , r914; one of them laid a string of 30 eggs the following night and these all hatched on July I4, an interval of Io days, the water being kept at the same temperature as that in the river $\left(72^{\circ} \mathrm{F}\right.$.). This is the shortest incubation period yet observed for any species of Argulus, and since the eggs were kept at the same temperature as the river water it must be close to the normal period.

The eggs are similar to those of A. maculosus (Proceedings U. S. National Museum, vol. 32, pl. 3I, fig. I5), the chicf differences being that they are not inclined to one another but are all in the same straight line, and while there are two large jelly masses at the junction of every two eggs there is no row of them standing out like the spokes of a wheel. The eggs were transparent and cream colored when first laid but became opaque within 36 hours, and the eyes appeared on the fifth day.

The newly hatched larvæ are much more active than those of maculosus and swim about rapidly with a steady gliding motion similar to that of the adult. At first they swim largely at the surface but later sink to the bottom. They are much more heavily pigmented than any larvæ thus far observed, especially through the center of the carapace and along the midine of the thorax, the pigment being the same color as that of the adult.

Carapace broadly elliptical, the width to the length in the proportion of $\mathrm{I}_{3}$ to $\mathrm{I}_{4}$; anterior margin evenly rounded and with a scattering fringe of very short hairs, amongst which are one or two longer ones on either side; posterior sinus broad and very shallow; free thorax and abdomen forming a wide triangle, whose base, the second thorax segment, is a little less than half the width and whose altitude is a little more than half the length of the carapace. Abdomen half the width of the last thorax segment and a hittle longer than wide; anal lamine small and rectangular, each armed with two short spines of about the same length.

In the first antennæ the hook of the basal joint is long and slender and reaches to the base of the terminal joint; the latter is spherical and armed with seven large setæ, whose tips reach beyond the margin of the carapace, while all the rest of the appendage is covered.

In the second antenna the entire endopod projects beyond the carapace, the distal joint of the basipod is twice the length of the proximal joint, the temporary exopod is curved backward, is distinctly threejointed, and is tipped with a single short spine.

The temporary mandibular palps are exactly like those of the maculosus larva, even to the spine connected with their base. The second maxillx ("anterior maxillipeds" ) are also similar and terminate in two sickle-shaped claws, of which the dorsal one is armed with three barbs.

The maxillipeds ("posterior maxillipeds") are five-jointed, the second and third joints armed on their ventral surface with spines and bristles. The first swimming legs have a two-jointed basipod, the distal joint armed along its anterior border with a row of short spines; the exopod is three-jointed and ends in two short spines; the endopod is one-jointed and terminates in two long nonplumose setæ. All the other swimming legs are uniramose, immovable stumps, each ending in a short and blunt spine. There are no traces of skin glands.

The eyes are large and close to the lateral margins; the ocelli are also exceptionally large and there are only ro or 12 in each eye. The pattern of the median' eye is also peculiar and very different from that of any other species. The sting connected with the mouth is long and projects far in front of the carapace.

Total length, $0.66 \mathrm{~mm}$; ; carapace, $0.40 \mathrm{~mm}$. long, $0.35 \mathrm{~mm}$. wide.

Remarks. - This species is fairly common on the gars in the river, and as it was recorded by Kellicott from the Niagara River at Buffalo it is probably as widely distributed as its host. Young specimens of both sexes, fully developed but only $1.50 \mathrm{~mm}$. in length, were obtained in the tow in considerable numbers during the middle and latter part of August in several of the slews and in "Sunfish Lake," near Fairport. 
"ihese tiny specimens were very active and moved about much more constantly and with more speed than the free-swimming forms. They were so thin as to be almost perfectly transparent and made excellent microscope mounts. Their abnormal abundance was doubtless due to the congested conditions in the places where they were found, as already noted (p. 335).

\section{Argulus stizostethii Kellicott. (P1. LXII, fig. 20.)}

Argulus stizostethii, Kellicott, Amer. Jour. Micros., vol. 5, p. 53; Wilson, Proc. U. S. Nat. Mus., vol. 25, p. 713, pl. I7.

Host and record of specimens.-This species was originally obtained by Kellicott from the wall-eye, Stizostedion vitreum, in the Niagara River near Buffalo. Adult specimens have been obtained by the author from wall-eyes and saugers, S. canadense, in the Mississippi River and from wall-eyes in Lake Maxinkuckee. Young specimens of both sexes less than $1.50 \mathrm{~mm}$. in length were taken in considerable numbers in the tow at "Sunfish Lake," near Fairport, August 2, I9I4. These were associated with A. lepidostei, the numbers of the two species being about even, but the males of both species much more numerous than the females.

Specific characters of female.-These small Arguli being transparent, it was possible to make out the nervous system with ease. Comparing it with that of other species, we may notice first the exceptionally large size of the eyes, each of which is as large as the entire supraesophageal ganglion. The optic nerves are also very large and swollen into a barrel shape.

The first of the ventral chain of ganglia is enlarged laterally to nearly twice the diameter of the four following ones, which are all the same width, but the second and fifth ones are three times the length of the third and fourth. The nerves are given off exactly like those in A. americanus (Proceedings U. S. National Museum, vol. 25, p. 633).

The supporting rods in the membranous border of the sucking disks are made up of Io or I2 parts; the basal one is a narrow oblong with concave sides, the second, third, fourth, and fifth are much wider but about the same length, convex posteriorly and concave anteriorly; the remaining parts are more or less completely fused into a narrow threadlike rod.

The bordering fringe is narrow and made up of short and stiff hairs. The male was fully described in the references above given, and there is nothing to add here.

Remarks.-This species is not as common as the preceding; it was originally obtained from the wall-eye, but Kellicott records that specimens placed in an aquarium with the long-nosed gar and some minnows fastened on them and eventually killed the minnows. This suggests that under natural conditions they may often fasten on other fish than their usual host, especially under the conditions prevailing in the slews and "lakes."

Its presence in such numbers in the tow is indicative that the species must be fairly common in the vicinity.

\section{Argulus appendiculosus Wilson.}

A rgulus appendiculosus Wilson, Proc. U. S. Nat. Mus., vol. 32, p. 419, pl. 32.

Host and record of specimens. - The types of this species were obtained from a sucker (species not given) at Montpelier, Vt., and were sent to the United States Bureau of Fisheries at Woods Hole, Mass., in August, ISgS.

Since the original description it has been found in several places in the Mississippi Valley, as follows: A single femaie from the outside of the channel cat, Ictalurus punctatus, at Cumberland Falls, Ky., July 7 , I9II, catalogue no. 39588, U. S. National Museum; a male and female from the outside of the sheepshead, A. grunniens, at Lock $2 \mathrm{I}$ on the Cumberland River in Kentucky, catalogue no. 43523, U. S. National Museum; several specimens of both sexes from the largemouth black bass, $M$. sal moides, at Fairport, Iowa, July 20, I9ı2, catalogue no. 43527 , U. S. National Museum; two males and two females from the outside of the redmouth buffalo, Ictiobus cyprinella, at Fairport, May 27, I910, catalogue no. 43542 , U. S. National Museum; a male and female from the smallmouth buffalo, $I$. bubalus, at Fairport, June 28, I9I4, catalogue no. $4776 \mathrm{r}$, U. S. National Museum. Isolated specimens were also obtained from the gizzard shad, Dorosoma cepedianum, the crappie, Pomoxis annularis, and the white bass, Roccus chrysops, which goes to prove that these fish at least serve as occasional hosts.

Remarks.-This species was established in 1907 upon 20 specimens taken from a sucker at Montpelier, Vt. and both sexes were fully described and figured in the reference above given. All that can be added here is a few data with reference to the color. Both sexes when alive are a transparent creamy white, covered on the dorsal surface of the carapace and abdomen with opaque white dots, circular in 
ontline, very minute and thickly scattered, especially near the margin of the carapace. On the carapace there are also blonches of pale reddish brown, much larger than the white spots and more widely scattered. Each blotcli has a small spot near the center where there is no pigment; immediately around this spot the pigment is deeper in color and pales gradually toward the edges. The dorsal surface of the thorax ower the eges is a rich golden yellow, thickly streaked with longitudinal rows of purplish brown blotches, smaller than those on the carapace, deeper in color, more uniform in size, and more regular in shape. Most of these blotches also have small circular spots free from pigment, sometimes two to four in the same blotch and of different sizes. The eyes are deep golden yellow, each separate facet with a dark purple center. The sperm receptacles are golden yellow.

Although the species was originally found outside of the Mississippi Valley, there seems to be no dunbt that it belongs here. Its wide distribution and the variety of hosts slow that its range is universal throughout the eastern and central United States.

\section{Argulus ingens Wilson.}

A roulus ingens Wilson, Proc. U. S. Nat. Mus., vol. 42, p. 233, pl. 30.

Host and record of specimens.-Both sexes of this species were obtained from the alligator gar, Lepisosteus tristoechus, at Moon Lake, Miss.

No alligator gars were captured during the present summer, but they are fairly common in the Mississippi River, and when carefully examined will probably yield specimens of this parasite.

Argulus nobilis Thiele.

Argulus nobilis Thiele, 1904, Mitteil. aus dem Zool. Mrus. Berlin, II Band, 4 heft, p. 28 , pl. 7, 8, fig. $64-76$.

Host and record of specimens. - Thiele found six females and one male of this species among the specimens of the Berlin Zoological Museum; the name of the host upon the museum label was given as "Lepidosteus aculeatus." No such association of names is known in ichthyological literature, nor is there any hint as to whether the mistake was made in the generic or the specific name, so that we are left in a quandary as to its identification. Thiele suggested that it may have been " $L$. viridis, "which is the name given by Günther to the alligator gar, but this was only a guess and was unaccompanied by any proof.

Remarks. - The present species differs from ingens in the relative size of the abdomen and carapace, in most of the details of the first and second antennæ, in the general structure and armature of the maxillipeds, and especially in the accessory sexual apparatus of the second and third swimming legs of the male. The two species resemble each other in their exceptionally large size, in the general form of the abdomen, and in the approximation of the two outer spines on the basal plate of the maxillipeds. Nothing is stated with reference to the respiratory areas of nobilis, but those of ingens are very peculiar,

If 'Thiele's conjecture that the alligator gar is the host of this species should prove true, it would greatly increase the probability that ingens and nobilis are synonymous, and Thiele's name would take precedence.

At present, however, there are so many specific differences, and the identity of the host is so uncertain, that we can only leave the species as described and await future developments.

\section{Argulus maculosus Wilson.}

Argulus maculosus, Wilson, Proc. U. S. Nat. Mus., vol. 25, p. 755, pl. I9.

Host and record of specimens. - The original types of this species were I f females and 3 males, found unlabeled in the National Museum collection, and a single female from the muscalonge, Esox nobilior, at Clayton, N. Y. Since then two females were obtained from the red-eye, Ambloplites rupestris, at Lake Maxinkuckee, Ind., August 8, I906, and a single female from the yellow catfish, Ameiurus natalis, August 22, from the same locality. Numerous specimens were subsequently obtained from the two catfish, Ameiurus nebulosus and A.natalis, at Lake Maxinkuckee, and these are evidently their true hosts. (Procecdings U. S. National Museum, vol. 32, p. 416).

Some egg strings were obtained from these last ripe females and have received catalogue no. 32826 , U. S. National Museum; the newly hatched larva (catalogue no. 32822 , U. S. National Miuseum) were fully described in the last reference above given.

Remarks.-There is nothing to add to the full descriptions already given. Only one mutilated specimen hes yet lecen found from the Mississipli Iiver, but as the two catfish are plentifully distributed throughout the valley no doubt more will be discovered in the future. 
Argulus versicolor Wilson.

Argulus versicolor Wilson, Proc. U. S. Nat. Mus., vol. 25, p. 716, pl. 20; vol. 27, p. 643, fig. 22-33, text.

Host and record of specimens.-This species was originally obtained from the common pickerel, Esox lucius, at Warren, Mass. It was also found at other localities in the same State. A male and female were taken from the same host at Lake Maxinkuckee, Ind., August I5, Igo6.

Remarks. - The single pair above mentioned are the only specimens of this species thus far found in the Mississippi Valley, but the host is one of the most widely distributed fish in America and other specimens should be discovered in the future. They are ustally found inside the mouth or in the gill cavity and not on the outside surface.

Argulus catostomi Dana and Herrick.

Argulus catostomi Dara and Herrick, Amer. Jour. Sci., vol. 3I, p. 297, unnumbered plate; Wilson, Proc. U. S. Nat. Mus., vol. 25, p. 709, pl. i3; vol. 32, p. 411, pl. 29.

Host and record of specimens.-This species was originally found upon a sucker near New Haven, Conn. It was taken by the present author from Catostomus bostonensis in MIassachusetts, and from C. catostomus at Lake Maxinkuckee, Ind., and from C. nigricans and C. catostomus in the Missequoi River at Swanton, Vt. The Maxinkuckee specimens have been given catalogue no. 32820 , U. S. National Museum.

Remarks.-Only one or two suckers were taken during the summer of I9I4 and no specimens were found upon them, but the species is in the valley and is probably as widely distributed as its host.

Argulus americanus Wilson.

Arguhus americanus WVilson, Proc. U. S. Nat. Mus., vol. 25, p. 718, p1. 21; vol. 27, p. 627, fig. I-21, text.

Host and record of specimens.-Originally obtained by Prof. Reighard from Amia calva in the laboratory aquaria at Ann Arbor, Mich., this species was afterward found on the same host at Lake Maxinkuckee, Ind. (catalogue no. 32825 , U. S. National Museum), and at Fairport, Iowa, August 26 , I9I2 (catalogue no. $4360 \mathrm{r}$, U. S. National Museum), and on Umbra limi in one of the aquaria at Fairport, Iowa, February 7, IgI (catalogue no. 43529, U. S. National Museum).

Remarks.-This species is a great aquarium pest and thus is more likely to attract notice than some of the others. It is widely distributed throughout the valley but fortunately sticks closely to the dogfish for a host. Its presence on the mud minnow as above recorded was probably only temporary, and apparently it does not infest other fish.

Both sexes of the adults and the larvæ are fully described and figured in the references given above.

\section{Argulus trilineatus Wilson.}

Argulus trilineata Wilson, Proc. U. S. Nat. Mus., vol. 27, p. 65I, fig. 34-38, text.

Host and record of specimens.--The type was a female taken from goldfish in an aquarium at Macon, Ga. Another female was obtained by L. V. Lewis in a bowl of goldfish at Henderson, Ky., October 30, I9I4, and sent to the National Museum for identification. It was afterward returned to Mr. Lewis.

Remarks.-In the reference given above the specific name ended in the letter "a" through an oversight of the author; it should end in "us" so as to agree with the genus name, and that change is here made.

It was gratifying to obtain a second specimen from Kentucky and thus to know that the species was a valid one and quite widely distributed. This latter location comes within the range of the present paper and so the species is here included.

\section{Argulus funduli Krøyer.}

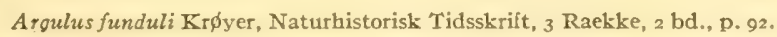

Host and record of specimens.--Krøyer found this species on the gills of a species of Fundulus near New Orleans. While this brings it into the Mississippi River, its host is a marine or brackish-water fish, and hence the parasite does not rightly belong among the fresh-water forms. The present author has found it repeatedly at Beaufort, N. C., and at Woods Hole, Mass., but always in salt water. 


\section{ERGASILIDA.}

Ergasilus lanceolatus, new species. (P1. Ixvi, fig. 40-46.)

Host and record of specimens.-Twenty females with egg strings were obtained from the gills of the gizzard or hickory shad, Dorosoma cepedianum, at Lock 2 I on the Cumberland River in Kentucky, July I6, I9II. This lot has been given catalogue no. 43555, U. S. National Museum, and from it has been selected a single female (catalogue no. 43556, U. S. National Museum) to serve as the type of the new species.

Specific characters of female.-General body form long and narrow, lanceolate; cephalothorax elliptical, one-half longer than wide, almost squarely truncated posteriorly, projecting a little anteriorly, with a small knob at the center of the anterior margin. First three free segments narrowed regularly backwards, the first of them (second segment) a little more than half the width of the carapace and about twice the width of the fourth segment; fifth segment very short and narrow; genital segment onehalf wider than the fifth segment, with strongly convex sides. Abdomen the same width as the fifth segment, three-jointed, the basal joint longer than the others; anal laminæ small, rectangular in outline, each armed with two setæ, the inner of which is 7 or 8 times the length of the outer one.

First antennæ six-jointed, the basal joint much longer than any of the others and armed with a very long, jointed seta, the other joints carrying shorter and simple setæ. Second antennæ not very large but powerful, basal joint short but much swollen and projecting strongly on the outer margin; second joint with a small stout spine near the center of the inner margin; terminal claw long, stout, and strongly curved.

The mouth parts project much more strongly than in any species thus far examined, both the upper and the under lips standing out prominently to form a long and sharp cone, from whose summit project on either side the long first maxillæ. Mandibles exceptionally large and thickset, the terminal portion tumed forward at right angles to the basal. The latter carries on its anterior margin, just outside the narrow neck, a bluntly rounded process projecting forward; the cutting blade is triangular in outline and armed with setæ along its inner margin only.

The palp is exceptionally long; starting from the posterior corner of the basal joint and reaching nearly to the center of the cutting blade with a row of corrugations along its outer margin.

First maxillæ small but projecting strongly, each armed with two plumose setæ; second maxillæ much smaller than the mandibles, but otherwise of the usual size and pattern. Endopods of the first, third, and fourth legs longer than the exopods; exopods of second legs longer than the endopods; all three joints of the endopods of the first legs and the two basal joints of the endopods of the second legs armed with minute teeth along their outer margins; exopod of fourth legs two-jointed, the basal joint twice the length of the terminal one. The arrangement of spines and setæ is as follows: First exopod, I-O, O-O, II-5; endopod, O-I, O-I, II-4; second exopod, III-O, I-I, I-6; endopod, $-\mathrm{I}, 0-2, \mathrm{I}-4$; third exopod, I-O, O-1, O-6; endopod, O-I, O-2, I-4; fourth exopod, O-O, I-4; endopod, O-I, O-I, I-2.

The egg strings when first extruded are conical, largest at the base and tapering to a single egg at the tip; when fully developed they are cylindrical and considerably shorter than the body; eggs in 5 or 6 rows, about ro eggs in a row.

Color (preserved material), a uniform light brown without pigment markings.

Total length, I mm.; cephalothorax, $0.60 \mathrm{~mm}$. long, $0.40 \mathrm{~mm}$. wide. Length of egg strings, 0.60 to $0.80 \mathrm{~mm}$.

(lanceolatus, lanceolate, alluding to the general body shape.)

Remarks.-This species is not associated as yet with any glochidium, but may well take the place of carulcus or centrarchidarum or versicolor.

Its jresence on the shad indicates that this fish would make a good host for some of the gill glochidia as well as for those already found upon its fins. Like other parasites found upon the herrings and their close relatives, this species does not infest any fish except its immediate host, and hence it is not likely to be found except on the gizzard shad.

\section{Ergasilus nigritus, new species. (P1. Lxvir.)}

Host and record of specimens. - Ten females, most of them with egg strings, were obtained from the gills of the largemouth bass Micropterus salmoides, in the Mississippi River at Fairport, Iowa, July 20 , I9I4. They have received catalogue no. 43562 , U. S. National Museum, and become cotypes of the 
new species, while a single female (catalogue no. 4356I, U. S. National Museum) has been selected to serve as the type.

Specific characters of female.-General body form short and squat; cephalothorax three-quarters of the entire length, one-fifth longer than wide, and strongly flattened dorsoventrally; dorsal surface moderately convex, ventral surface flat, with the mouth projecting but little, if any.

Antennal area rectangular in outline with rounded corners and projecting strongly anteriorly, so that the bases of both pairs of antennæ are carried in front of the body of the carapace. This latter is about as long as wide, is slightly narrowed posteriorly, and shows a distinct dorsal groove and marginal sinus separating the head from the first thorax segment, which is only one-fifth the length of the head. Second (first free) segment abruptly narrowed to half the width of the first and very short; remaining thorax segments also short and narrowed regularly backward; fifth segment concealed dorsally between the fourth and genital segments; the latter considerably wider and three times the length of the fourth segment, with strongly convex sides. Abdomen three-jointed, joints about the same length but narrowing posteriorly and indistinctly differentiated; anal laminæ small and rectangular, each bearing two setæ, of which the inner one is twice the length of the outer, and about the same length as the free thorax and abdomen.

Egg strings ovate and strongly divergent, only one-fourth longer than wide, and so much inflated that they meet dorsally at the midline; eggs large, arranged in eight or nine longitudinal rows, about seven eggs in the longest rows. First antennæ six-jointed, the penuitimate and basal joints longer than the others and all the joints heavily armed with setæ; second antennæ long and stout, the basal joint much inflated and quite convex externally, the terminal claw stout and strongly curved.

Mouth parts rather small and effectively concealed beneath the upper lip, not projecting as in other species but flattened with the rest of the ventral surface. Mandibles with a narrow cutting blade, armed with setæ along the inner margin only; palp about as long as the cutting blade, armed with setæ or toothed along the posterior margin.

First maxillæ with a large base and two stout setæ; second maxillæ with a straight cutting blade, fringed with setæ along both margins, basal joint large and rectangular. Endopods of first and fourth legs much longer than exopods, the two rami of the second and third legs equal; exopod of fourth legs two-jointed. The arrangement of the spines and setæ is as follows: First exopod, $\mathrm{I}-0,0-\mathrm{x}, \mathrm{II}-5$; endopod, O-I, O-2, I-4; second exopod, I-O, O-I, O-6; endopod, O-I, I-2, O-5; third exopod, ०-0, ०-I, O-5;

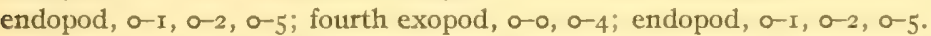

Color (preserved material), young females a uniform creamy white without pigment; in later development black pigment appears in scattered spots on the dorsal surface of the carapace and gradually covers the entire copepod, including even the swimming legs and anal laminæ and setæ but not the second antennæ.

Total length, $0.70 \mathrm{~mm}$.; carapace, $0.50 \mathrm{~mm}$. long, $0.40 \mathrm{~mm}$. wide. Egg strings, $0.35 \mathrm{~mm}$. long, 0.23 mm, wide.

(nigritus, blackened.)

Remarks. - This tiny species may be recognized at once by the jet-black color of the mature adults and by the very short and thickset egg strings.

It can not be very common, since only the single lot has been obtained from many hundreds of largemouth black bass which have been examined for copepod parasites. It seems to take the place on this bass of caruleus upon the other Centrarchidæ, being associated with Lampsilis glochidia.

Ergasilus megaceros, new species. (P1. LxvI, fig. 49; p1. Lxvmi, fig. 57-6r.)

Host and record of specimens.-Four females, two of which had egg strings, were taken from the lamellar plates in the nasal fossæ of a Fulton cat, Ictalurus anguilla, captured at Fairport, Iowa, May I6, I9I4. Three of these specimens have been given catalogue no. 43548, U. S. National Museum, and become cotypes of the new species, the fourth and best one (catalogue no. 43544 , U. S. National Museum) becoming the type.

Specific characters of female.-General body form long and slender; cephalothorax ovate, one-half longer than wide, narrowed and pointed anteriorly, squarely rounded posteriorly; first thorax segment as wide and half as long as the head and separated from the latter by marginal sinuses and a distinct dorsal groove; eye far forward just behind the bases of the first antennæ; thorax segments diminishing regularly in size backward, the fifth one very short; genital segment the same width as the fourth seg- 
ment, with strongly convex sides. Abdomen three-jointed, the joints all about the same width and length; anal laminx nearly as long as the entire abdomen, narrow and enlarged at the tip into a rounded knob on the outer margin, each tipped with two long plumose setæ, the inner of which is one-half longer than the outer. Egg strings elongate ellipsoids, a little shorter than the cephalothorax; eggs large, arranged in 6 or 7 longitudinal rows, about 8 eggs in the longest rows.

First antenna exceptionally large, six-jointed, the jointing indistinct, the fourth segment carrying on the inner distal corner a huge jointed seta, which reaches back to the center of the second thorax segment; the terminal joint is tipped with another huge seta, unjointed but nearly as long as the jointed one. Second antennæ also long but slender, the terminal claw bluntly rounded. Mouth tube protruding strongly; mandibles with a short neck and cutting blade, turned forward diagonally; palp long and narrow and armed along its inner margin with short bristles.

First maxillæ of the usual pattem; second maxillæ meeting on the midline, the cutting blade short and small and armed with a few sharp spines. Findopods of the first and fourth legs longer than the exopods; rami of the other legs equal; arrangement of the spines and setæ as follows: First exopod, $I-O, I-I, I-6$; endopod, $0-I, 0-I, 0-6$; second exopod, $I-0, I-I, I-5$; endopod, $0-1,0-2, I-4$; third exopod, $\mathrm{I}-0, \mathrm{I}-\mathrm{I}, \mathrm{I}-5$; endopod, $\mathrm{O}-\mathrm{I}, \mathrm{O}-2$, I-4; fourth exopod, I-O, I-4; endopod, $0-\mathrm{I}, 0-2, \mathrm{I}-3$.

Color, a transparent yellowish white, oviducts white, egg tubes yellow, the ventral surface of the carapace and thorax covered with irregular patches of a light sky-blue pigment.

Total length, $x \mathrm{~mm}$; carapace, $0.50 \mathrm{~mm}$. long, $0.40 \mathrm{~mm}$. wide; first antennæ, including setæ, 0.60 $\mathrm{mm}$, long. Ëgg strings, $0.40 \mathrm{~mm}$. long.

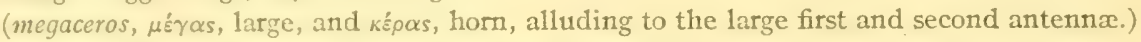

Remarks.--So far as known, this is the first parasitic copepod to be found in the nasal fossæ of any fresh-water fish. They are common in both the nasal fossæ and spiracles of sait-water fish, sharks, and rays, and probably the reason why they have never been found in fresh-water fish is simply because they have never been looked for. The nostrils of this catfish were only quarter of an inch in diameter, and hence the ergasilid larva must do some strenuous hunting to find its chosen place on the host. It is more than likely that the examination of similar fossæ on other large fresh-water fish will yield specimens of this or similar species. Being found thus in the nose, the species can not be associated in any way with mussel glochidia, but its presence emphasizes the testimony of those species found on the gills, that the Fulton cat would make a good host for glochidia. If the ergasilid larva can find its way into the nose of these fish, it is possible that the mussel glochidium can perform the same feat. At all events it will be worth while to examine the nose of large fishes for both copepods and glochidia.

\section{Ergasilus elongatus, new species. (P1. Lxvi, fig. 47, 48; pl. LxvII, fig. 62-66.)}

Host and record of specimens.-Twenty-five females with egg strings were obtained from the gill rakers of the spoonbill cat, Polyodon spathula, from the Mississippi River at New Boston, Ill., July, I9I4, catalogue no. 47764 , U. S. National Museum. Thirty females from the same host at Keokuk, Iowa, August 28, 19I4, catalogue no. 47763 , U. S. National Museum. A single female (catalogue no. 47765 , U. S. National Museum) has been selected from this last lot to serve as the type of the new species. Sections of two gills of the same fish, with specimens of the species in situ, have received catalogue no. 47762 , U. S. National Museum.

Specific characters of female.-General body form an elongate ovoid, the larger end anterior; cephalothorax one-half longer than the rest of the body, widest at its center, strongly tapered anteriorly, almost squarely truncated posteriorly. Antennal area reaching the entire width of the anterior end and distinctly separated from the rest of the head.

Free thorax segments diminishing regularly in width and length from in front backwards; fifth segment plainly visible and lialf the width of the fourth; genital segment barrel shaped, its sides moderately projecting. Abdomen segments the same length but diminishing regularly in width; anal laminx half as long again as the last abdomen segment, narrow with square corners, each tipped with two short setæ, the inner of which is one-half longer than the outer. Egg strings to the entire length of the body as 8 to Ir, rather narrow; eggs arranged in 6 or 7 longitudinal rows, about 25 in the longest rows.

First antennæ rather slender and short, six-jointed, and sparsely armed with setæ; second antennæ also short but stout, not long enough to reach more than halfway around the gill raker, but clasping it so tightly as to make a groove in it. Mouth tube exceptiunally far forward and not projecting as strongly as in most species; upper lip rather square, and entirely covering the mouth parts. Mandibles as large 
as the second maxillæ, cutting blade turned forward at right angles to the base, very wide and armed with setrealong both margins; palp short and narrow, with a row of comblike teeth along its inner margin. First maxillæ small and inconspicuous, not visible in side view owing to the fact that they are covered by the upper lip; second maxillæ small, the cutting blade narrow and armed with setæ along both margins. This species resembles elegans in having the endopod of the first legs as well as the exopods of the fourth pair two-jointed.

The arrangement of the spines and setæ is as follows: First exopod, I-0, I-2, III-5; endopod, o- $\mathrm{I}$, II-6; second exopod, I-O, I-I, I-7; endopod, $-1,0-2, I-5$; third exopod, I-O, II-0, I-5; endopod, o-I, $0-2$, II-5; fourth exopod, $-0, I-5$; endopod, $-\mathrm{I}, 0-2, \mathrm{I}-4$. The oviducts are so arranged that when filled with ripening eggs they do not distort the shape of the cephalothorax as in other species.

Color, a transparent grayish white, oviducts and egg strings dark yellow, ventral surface covered with an interlaced network of lines and patches of indigo blue.

Total length, r.40 mm.; cephalothorax, $0.85 \mathrm{~mm}$. long, $0.30 \mathrm{~mm}$. wide. Egg strings, I mm. long.

(elongatus, elongate, alluding to the general body form.)

Remarks. - This species is unique in its general body form as well as in its habitat and may be recognized by either peculiarity. It will be remembered that in the paddle fishes, to which the spoonbill cat belongs, the gill rakers are very long and slender and in a double series on each gill arch, the series separated by a broad membrane. These copépods were fastened to the rakers, sometimes on the outside, sometimes on the inside between the raker and the membrane, with their head indifferently in either direction, toward the arch or away from it, and the short but stout second antennæ grasped the raker firmly enough to make around it a groove from which the copepod could not be separated except by cutting the raker close to the antennæ.

So far as known this is the only instance of any of the Ergasilidæ fastening itself to the bony gill rakers instead of the soft filaments, and this makes the strength of the attachment the more worthy of notice.

Apparently this species is not connected with any glochidium, but this may be changed later when the spoonbill cat has been further and more extensively examined. The body is fully as thick as it is wide and the carapace fits snugly on the general contour, giving the copepod a peculiarly clean and graceful appearance.

\section{Ergasilus elegans, new species. (PI. Lxrx, fig. 67-73.)}

Host and record of specimens. - This species was captured several times in the tow at Patterson Iake and "Sunfish Lake" before it was found on any fish host; these free-swimming specimens have been given catalogue no. 47767 , U.S. National Museum, and are all without egg strings. A second lot with egg strings was obtained from the gills of the bullhead, Ameiurus melas, caught in "Sunfish Lake," August 24, I9I4; they have been numbered catalogue no. 47768 , U. S. National Museum. A single female has been selected from this lot to serve as the type of the new species, with catalogue no. $47769, \mathrm{U}$. S. National Museum. A few were also obtained from the gills of the long-nosed gar, Lepisosteus osseus, in the Mississippi near Fairport, Iowa, catalogue no. 47766, U. S. National Museum. Others were found on the gills of the short-nosed gar, L. platostomus, from Patterson Lake, August 6, I9r4.

Specific characters of female.-General body form elongate; cephalothorax one-half longer than wide, the first thorax segment distinctly separated from the head and somewhat narrower; carapace well rounded and scarcely projecting anteriorly; antennal area poorly differentiated.

Second, third, and fourth thorax segments about the same length and diminishing regularly in width, fifth segment scarcely visible; genital segment barrel-shaped, with moderately projecting sides. Abdomen three-jointed, joints about the same length but diminishing slightly in width; anal setæ as long as the last two segments, twice as long as wide, with square comers, each tipped with two setæ, a longer, jointed one at the inner comer, and a shorter oblique one at the outer corner.

Egg strings less than half the length of the body and rather wide; eggs exceptionally large and arranged in two rows, $I_{5}$ or 18 eggs in each string. First antennæ six-jointed and heavily armed with setæ; second antennæ very long and slender, basal joint short and not swollen; second joint and terminal claw the same length, the former with a small spine on its ventral surface, the latter bent into a half circle. Mandibles with a rectangular base abruptly narrowed into the neck, which is half as long as the base and is tipped with a triangular cutting blade, heavily fringed with setæ around its entire margin; palp as long as the cutting blade, narrow and armed along the inner margin with a row of heavy, comblike $16825^{\circ}-16-3$ 
teeth. First maxillæ small but protruding well and armed with long setæ; second maxillæ with a broadly triangular blade, fringed only along its posterior margin; muscles and rudiments of the maxillipeds present behind the second maxilla; lower lip a small narrow, semicircular plate behind the tips of the second maxille. Endopod of the first swimming legs and exopod of the fourth legs two-jointed; all the other rami three-jointed; arrangement of the spines and setæe as follows: First exopod, I-O, 0-I, II-5; endopod, O-I, II-5; second exopod, I-0, O-I, I-6; endopod, o-I, O-2, I-4; third exopod, I-0, O-I, I-5; endopod, O-I, O-2, I-4; fourth exopod, I-O, I-5; endopod, O-I, O-2, I-3.

Ground color that of transparent cartilage, covered over the entire ventral surface with large irregular patches of deep purplish blue; these coalesce into a line along either side of the digestive tract, which latter is a rich golden yellow; on the bases of the antennx and mouth parts, around the eyes, and outside the blue line in the genital segment are patches of pale brick red; the compound eye is dark purple.

Total length, I.25 mm.; cephalothorax, $0.60 \mathrm{~mm}$. long, $0.40 \mathrm{~mm}$. wide. Egg strings, $0.50 \mathrm{~mm}$. long.

(elegans, elegant, neat in appearance.)

Romarks. - This species closely resembles versicolor, but can be readily distinguished by the twojointed endopod of the first legs. From all the other species it is at once distinguished by its varied coloration, as well as by its frec-swimming habits. It is associated with Lampsilis anodontoides, the yellow sand-shell, and apparently with no other glochidia. Accordingly it is likely to be found upon the alligator gar at the right season.

In swimming the large second antennæ are folded like arms across the thorax, and neither they nor the first antenna are used for locomotion.

Movement is accomplished entirely by means of the swimming legs and consists of a series of rapid dashes, without any particular direction.

These movements are swifter and they carry the copepod many times farther than those of the regular free-swimmers, so that if the tow be placed in a large shallow glass these free-swimming parasites can be at once detected by their movements. Apparently this species swims about freely in the slews until its eggs are ripe, since the females obtained from the tow are fully as large as those from the fish.

Like the young Arguli they frequent the surface in the daytime and sink to lower depths at night, and they must fasten upon the fish when fully matured rather than in a larval stage.

\section{Ergasilus cæruleus Wilson. (P1. LXIX, fig. 74.)}

Ergasilus caruleus Wilson, Proc. U. S. Nat. Mus., vol. 39, p. 334, pl. 43.

Host and record of specimens.-When this species was established it was found only upon bluegills in Tippecanoe Lake and Twin Lakes, Ind. Here in the Mississippi River, however, it is extremely abundant; its chief hosts are the two crappies, Pomoxis annularis and $P$. sparoides.

From the former lots have been obtained which have received catalogue no. 4353 I, 43535, 43530, 43532 , U. S. National Museum; from the latter the lots are catalogue no. 43545,435 I 4 , U. S. National Museum. Catalogue no. 4354I, U. S. National Museum, contains a set of gills just as they were taken from $P$. annularis, with the parasites preserved in situ, and nearly 500 of them upon the single fish.

A single female (catalogue no. 43538 , U. S. National Museum) was obtained from the blue-spotted sunfish, Apomotis cyancllus; several (catalogue no. 47774, U. S. National Museum) were taken from the bluegill, Eupomotis gibbosus, captured near Fairport, Iowa; two were found on the sauger, Stizostedion canadense (catalogue no. 47776 , U. S. National Museum); three on the gills of the white bass, Roccuschrysops (catalogue no. 47777, U. S. National Museum); and one on the gills of the long-nosed gar, L. osseus. These fish were all captured in the Mississippi River at or near Fairport during the present season.

Newly hatched nauplius larva.- Some of the females obtained on August I4 were carrying eggs whose blue color showed that they were ready to hatch. These were accordingly placed in a suitable aquarium and all hatched out on the following day. The issuing nauplius proved to be quite similar to that of Ergasilus centrarchidarum, but with these differences:

General body form ovate, considerably narrowed and pointed posteriorly, and nearly twice as long as wide; the knob at the posterior end, the future abdomen, is much larger than in centrarchidarum and projects farther. The three pairs of appendages are similar in all their general features to those of the other Iirgasilide and differ only in little details. The basal joint of the first pair is sumewhat swollen; the masticatory process on the scend pair is proportionally large and carries a very long spine which is not much curved; the lamina shaped like the blade of a case knife, found upon the endopod of the third appendages, is sometimes jointed and is relatively large. 
The upper lip is diamond shaped, considerably longer than wide, the anterior end well rounded, the posterior end pointed, and reaching some distance behind the masticatory processes of the second antennæ.

The balancers at the posterior end of the body are straight instead of curved and stand at an angle of about 45 degrees with the body axis.

Remarks. - The large numbers (500 or more) of specimens found upon a single fish are worthy of notice; in some instances it does not seem as if any more could be crowded upon the gills, three or four copepods being found, one above another, upon the same filament. Like the original specimens from the bluegills, they are always found on the inner side of the gill filament, between the rows of filaments on the same arch.

Here in the Mississippi Valley the two crappies are evidently the chief hosts of the species and it is worthy of note that they are vegetable feeders like the bluegill. This species of Ergasilus therefore may be fairly regarded as a parasite of the vegetarian Centrarchidæ.

It is also worth recording that of the many hundreds of caruleus examined every one was scrupulously clean; there were no protozoa or algæ upon any of the specimens. This is in marked contrast to the following species from the catfishes, nearly every specimen of which is covered with these parasites. The present species is associated with the Lampsilis group of glochidia and has been found upon every species of fish that serve as hosts for these glochidia except the sheepshead and the largemouth black bass, on which latter fish it is replaced by $E$. nigritus, a new species.

\section{Ergasilus versicolor Wilson.}

Eroasilus versicolor Wilson, Proc. U. S. Nat. Mus., vol. 39, p. 34x, pl. 45.

Host and record of specimens.-Originally found upon two species of catfish at Lake Maxinkuckee, Ind., this ergasilid proves to be even more abundant upon the catfishes of the Mississippi, and the following lots were obtained during the summer: Catalogue no. $4355^{8}$, U. S. National Museum, from the gills of the skipjack, Pomolobus chrysochlorus, taken in Lake Pepin and sent to Fairport July 23; catalogue no. 47770 , U. S. National Museum, from the gills of the channel cat, Ictalurus punctatus, taken at Fairport July 25; catalogue no. 43533, U. S. National Museum, from gills of channel cat taken at Fairport September 2, 1910; catalogue no. 43560, U. S. National Museum, from gills of the bullhead, Ameiurus nebulosus, taken in Patterson Lake July 3; catalogue no. 43509, U. S. National Museum, from gills of the Fulton cat, Ictalurus anguilla, taken at Fairport May I4, I9I4.

Remarks.-All these specimens except those included in no. 47770 were heavily infested with parasitic protozoa and fresh-water algæ, and some were so thoroughly covered as to be effectively concealed. This is probably due in part to the feeding habits of their hosts, all of whom stick close to the mud at the bottom of the river.

The species is associated with the Quadrula group of glochidia and in all probability will be found upon Leptops olivaris, the mud cat.

\section{Ergasilus centrarchidarum Wright.}

Ergasilus centrarchidarum Wright, Proc. Canadian Institute, n. S., vol. x, p: 243, pl. I; Wilson, Proc. U. S. Nat. Mus., vol. 39, p. 33 I, pl. 42.

Host and record of specimens. - In addition to those found upon various hosts at Lake Maxinkuckee, Ind., and recorded in the last reference given above, the following lots were obtained during the past summer: Catalogue no. 43507, U. S. National Museum, from the gills of Pomoxis annularis, taken in the Mississippi at Fairport, May 25, I9I0; catalogue no. 43537, U. S. National Museum, from the gills of the largemouth black bass, $M$. salmoides, taken in Crooked S Slew, Fairport, May 26, I9Io; catalogue no. 47778 , U. S. National Museum, from the gills of the white bass, Roccus chrysops, taken at Fairport, August 6; catalogue no. 47775 , U. S. National Museum, from the gills of the sauger, S. canadense, taken at Fairport, August I4; catalogue no. 47779, U. S. National Museum, from the gills of the largemouth black bass, taken in Patterson Lake, August 6; catalogue no. 47780, U. S. National Museum, from the gills of the warmouth, Chcnobryttus gulosus, taken in Patterson Lake, August 6. A single female was also obtained from the gills of the green sunfish, Apomotis cyanellus, taken at Fairport, August io.

Remarks.-This species is frequently associated with caruleus upon the same host, but the two can always be separated by their position on the gill filaments; centrarchidarum is always on the outside, while caruleus is as constantly on the inside between the two rows of filaments, and no exception has yet been found to this rule. 
This species is associated with glochidia of the Quadrula group, and its presence in considerable numbers upon any fish indicates that its host would make a good carrier of Quadrula glochidia. It is worliy of note that these two species, centrarchidarum and coruleus, which accompany the two groups of glochicial, are associated upon those fish which serve as hosts for the glochidia and are often found torether. while centrarchidarum and zersicolor are never found upon the same fish although they accompany the same group of glochidia.

\section{Ergasilus chautauquaensis Fellows.}

Eroasilus chautauquaensis Fellows, Proc. Amer. Soc. Microscopists, vol. 9, p. 246, I plate, unnumbered; Wilson, Proc. U. S. Nat. Mus., vol. 39 , p. 343 , pl. 46.

Host and rccord of specimens.--This species was originally discovered in the tow of Lake Champlain and both sexes were afterwards found by the present author in some samples of tow from Lake Mendota at Madison, Wis.; these specimens received catalogue no. 386r7, U. S. National Museum. It has not thus far been found upon any fish, but in all probability its habits are like those of the new species elegans. The males are free-swimmers throughout life and the females swim freely until their eggs are ready to pass out into the external sacks. The present species will probably be found at another time of year upon the gills of some fish in Lake Champlain or Lake Mendota.

\section{Ergasilus funduli Krøyer.}

Ergasilus funduli Krфyer, Naturhistorisk 'Tidsskrift, (3), vol, 2, p. 228, pl. rx, fig. I, a-f; Wilson, Proc. U. S. Nat. Mus., vol. 39, p. 328 .

Host and record of specimens.-Krøyer found a few specimens of this species on the gills of Fundulus ocellaris (F. limbatus Krøyer) taken near New Orleans in the Mississippi River. This is another of the marine or brackish water fish that comes up the river a little ways, but its parasites can not be regarded as true fresh-water species.

\section{Ergasilus lizæ Kroyer.}

Ergasilus lize Kroyer, Naturhistorisk Tidsskrift, (3), vol. 2, p. 232; Wilson, Proc. U. S. Nat. Mus., vol. 39, p. 340.

Host and record of specimens.-This is another species captured by Kroyer near New Orleans on the gills of Mugil curema (M. liza Krøyer). Like the preceding, it can not be regarded as a true fresh-water species, neither have any further specimens ever been found.

\section{LERNAOPODIDE.}

\section{Salmincola californiensis (Dana). (P1. Lxx.)}

Lemcopoda californiensis Dana, U. S. Exploring Fixpedition during the years 1838 to I 842 , vol. I2, p. I379. pl. 96, fig. 1a, rb. Salmincola californicnsis Wilson, Proc. U. S. Nat. Mus., vol. 47, p.605.

Host and record of specimens.-Eight females were obtained from the gills of Oncorhynchis nerka at Big Payette Lake, Idaho, June, I9I4, and were sent to the auther from the United States Bureau of Fisheries. They have received catalogue no. 43563 , U. S. National Museum, and since Dàn's original specimens have been lost they will serve as surrogate types of the species.

Specific characters of female.-Dana's original description and figures were excellent as far as they went, but he included only the general body characters and no appendages were mentioned except the second maxillæ.

These new specimens show a wider and shorter body, strongly flattened on the ventral surface, and in the larger females showing distinct ventral grooves of segmentation. The cephalothorax is inclined nearly at right angles to the trunk; the contour of its dorsal surface is clearly shown in figure 77 and is very different from that of any other species of the genus, approaching most closely that of salmonea.

The first antennxe are very short, apparently three-jointed, and tipped with a minute spine; the second antennx are long and stout, the basal portion two-jointed, the rami one-jointed and about the same size, the exopod tipped with a fairly large chela, the endopod with two or three small spines; on the ventral surface of the exopod near the base of the clela is a peculiar compound spine. The mandibles are long and slender, with strongly hooked teeth; the first maxillæ are short, somewhat swollen at the center, and end in three small spines of about the same size; the second maxillæ in younger specimens are snim th and lonerer than the trunk, in older females much wrinkled and shorter than the trunk. The maxillipeds are large and stout, the basal joint considerably swollen and armed on its inner margin 
near the distal end with a small papilla like those in other species; the terminal joint is slender and is tipped with a larger and a smaller claw, somewhat like a chela.

Total length (larger specimens), $4.40 \mathrm{~mm}$.; cephalothorax, I.60 mm. long, $2.40 \mathrm{~mm}$. wide; trunk, $2.75 \mathrm{~mm}$. long, $3.30 \mathrm{~mm}$. wide. Egg strings, $5.40 \mathrm{~mm}$. long, $1.25 \mathrm{~mm}$. wide. Bulla $1.65 \mathrm{~mm}$. in diameter.

Remarks.-It is gratifying to obtain new specimens of Dana's species, probably from the same host. They confirm his description in all its essential features and enable us to supply the details of the appendages which were lacking. They also establish the species beyond any doubt, as is shown by the dorsal contour of the cephalothorax, the general body form and proportions, and the details of the mandibles, second antennæ, and first maxillæ.

\section{Salmincola siscowet (Smith).}

Lerneopodu siscowet Smith, Report U. S. Commissioner Fish and Fisheries for 1872-73, pt. 2, p. 664, pl. 3, fig. I5, I6; TVilson, Proc. U. S. Nat. Mus., vol. 47, p. 608 , p1. 30, fig. 23-29.

Host and record of specimens.- Seven females were taken from the gills of Cristivomer namaycush siscowet at Outer Island, Lake Superior, by J. W. Milner; they are numbered 39597, U. S. National Museum.

\section{Salmincola edwardsii (Olsson).}

I.erncopoda edwardsii Fasten, Report Wisconsin Commissioners of Fisheries for I9II-I2, p. II, 4 unnumbered plates; Biol Buil., vol. 27, p. 116, pl. I-3.

Salmincola edwardsii Wilson, Proc. U. S. Nat. Mus., vol. 47, p. 609, pl. 30, fig. $30-35$.

Host and record of specimens.--Twenty-five females (catalogue no. 43574, U. S. National Museum) from gills of brook trout, Salvelinus fontinalis, at Wild Rose, Wis. Others have been obtained from the same host at Caledonia, N. X.; Houghton, Mich.; Northville, Mich.; St. Paul, Minn.

Remarks. - This species often causes serious trouble in fish hatcheries, loading the gills of the trout until they are suffocated and large numbers of them perish. Each of the lots mentioned above have come from hatcheries thus afflicted, and Fasten's first paper gives an excellent account of the disease produced in brook trout by this parasite.

\section{Salmincola oquassa Wilson.}

Salmincola oquassa Wilson, Proc. U. S. Nat. Mus., vol. 47, p. 6ri, pl. 31, fig. 36-40.

Host and record of specimens.-Five females were obtained from the blueback trout, Salvelinus oquassa, at Rangely Lakes, Me., November 27, I884; they have received catalogue no. 39604, U. S. National Museum.

\section{Salmincola bicauliculata (Wilson).}

Lerncopoda bicauliculata Wilson, Proc. U. S. Nat. Mus., vol. 35, p. 472, pl. 82.

Salmincola bicauliculata Wilson, idem, vol. 47, p. $6 \times 2$, pl. 31 , fig. $4 I_{3} 42$.

Host and record of specimens.-A single female was taken from a "trout" at Mapleton, Oreg., by Dr. S. E. Meek in 1896 and has received catalogue no. 38575 , U. S. National Museum.

\section{Salmincola falculata (Wilson).}

Lerncopoda falculata Wilson, Proc. U. S. Nat. Mus., vol. 35, p. 473, p1. 83.

Salmincola falculata Wilson, idem, vol. 47, p. 6I3, pl. 3 I, fig. 43,44 .

Host and record of specimens.-Four females from the gills of Oncorhynchus nerka at Baker Lake, Wash., in I902, catalogue no. 38586 , U. S. National Museum. Three other lots were obtained by the Bureau of Fisheries from trout in California, catalogue no. $38588,38589,38590$, U. S. National Museum.

Salmincola inermis (Wilson).

Lerncopoda inermis Wilson, Proc. U. S. Nat. Mus., vol. 39, p. 632, pl. 68.

Salmincola inermis Wilson, idem, vol. 47, p. 6r4, pl. 32, fig. 47-5x.

Host and record of specimens.-This species has been found abundantly upon the lake herring, Argyrosomus artedi, in Lakes Huron and Superior and in rivers running into them.

Salmincola beani (Wilson).

Lerncopoda beani Wilson, Proc. U. S. Nat. Mus., vol. 35, p. 470, pl. 8I.

Salmincola beani Wilson, idem, vol. 47, p. 6 r $_{5}$, pl. 32 , fig. 52,53 .

Host and record of specimens.-Found in considerable numbers on the gills of the quinnat salmon, Oncorhynchus tschawytscha, in McCloud River, Cal., and at Battle Creek, Colo. 
Salmincola carpenteri (Packard).

A chtlecres carpenteri Packard, Annual Report U. S. Geol. and Geog. Survey of the Territories for $x 873$, p. $612, x$ text figure. Salmincola carpenteri Wilson, Proc. U. S. Nat. Mus., vol. 47, p. 6r6, pl. 33, fig. 54-60.

Host and record of specimens.- From the gills of "trout" in a tributary of the East River, Colo., and from "salmon" at Battle Creek, Colo; the former host has been identified by R. R. Gurley as Salmo mykiss.

Remarks.-Neither this nor any of the other species of the genus have ever been found associated with any glochidium, but not because the two are uncongenial. Very few, if any, of the species of trout and salmon have been examined for glochidia, because usually the streams and lakes in which they live are inhabited by only a few mussels, none of which are of any value commercially. Furthermore, neither of the two kinds of fish are found in those localities where artificial infection has been tried, and thus there has been no chance to ascertain whether they will take the glochidia or not. But the susceptibility of these fish to copepod parasites would lead us to suppose that they would make good hosts for glochidia. In all probability future examination will discover glochidia upon some of them, and if artificial propagation is tried in lakes as well as rivers there would seem to be no reason why these fish could not be used as carriers for the glochidia.

\section{Achtheres pimelodi Krøyer. (P1. LXxi.)}

Achtheres pimclodi Krøyer, Naturhistorisk Tidsskrift, 3 Raekke, 2 bd., p. 272, pl. r7, fig. 5a, 5b; Wilson, Proc. U. S. Nat. Mus., vol. 47, p. 628, pl. 38 .

Host and record of specimens. - Both sexes have been obtained from the gill arches of various catfish; from Ictahurus punctatus at Cincinnati, Ohio; from Ameiurus nebulosus at Put-in Bay, Ohio; from Ictalurus anguilla and Leptops olivaris at Fairport, Iowa. From the former of the last two a female was obtained and numbered 47726 , U. S. National Museum; from the latter a female with ripe eggs, which has been given catalogue no. 4777 I , U. S. National Museum.

First copepodid larva.-The egg strings of the ripe female just mentioned were detached and the larvæ hatched out in an aquarium, August 22, Igr4. These larvæ differed in several important particulars from those of ambloplitis already described (Proceedings U. S. National Museum, vol. 39, p. 208), as may be seen by the following:

Cephalothorax elliptical, the breadth to the length as ir to 17 , not enlarged anteriorly over the base of the second antennx; head separated from the first thorax segment by lateral notches, but without a well-defined groove; posterior lobes large and evenly rounded. Attachment end of the filament exceptionally large, somewhat quadrate in dorsal view, and close to the frontal margin; coiled portion of the filament also unusually long and situated far back in the cephalothorax. Dorsal color patch about the same size as the attachment end of the filament, shield-shaped, and placed nearly at the center of the cephalothorax. Posterior portion of the body made up of four segments, all the same width, but diminishing in length backwards, the fourth one about one-third the length of the first, which latter carries on its sides, the rudiments of a third pair of swimming legs. Anal laminæ twice the length and more than half the width of the last segment, so that they overlap on the midline, each armed with two large sword-shaped, jointed setxe on the inner side and three shorter ordinary ones on the outer margin.

First antennæ four-jointed and heavily armed with setæ; second antennæ similar to those in ambloplitis; mandibles short and thickset, made up of a single spherical joint tipped with a stout spine and carrying a triangular palp on the outer margin. First maxillæ two-jointed, the basal joint spherical, the termina! one long and pointed; second maxilla with a strongly swollen, almost spherical basal joint and a stout terminal claw, bent at right angles near its center; maxillipeds comparatively slender, with two unarmed joints and a stout curved claw. Swimming legs similar in all respects to those of ambloplitis, biramose, each ramus one-jointed, the exopods tipped with four plumose setæ, the endopods with six.

Total length, $0.45 \mathrm{~mm}$.; width of cephalothorax, $0.20 \mathrm{~mm}$.

Remarks.-The most noticeable differences between the present larva and that of ambloplitis are the lack of separation of the first thorax segment, the comparatively enormous attachment filament, the swordlike setx on the anal laminx, and the bulky, swollen form of the mandibles, first and second maxillx. In the present larva also the mandibles have a rudimentary palp while the first maxillx have none, the reverse being the case in ambloplitis. There are four patches of pigment, but the dorsal patch and the posterior ventral one are relatively much larger than the others, which are reduced to minute spots. 
Achtheres corpulentus Kellicott.

Achtheres corpulentzs Kellicott. Proc. American Soc, Microscopists, vol. I, p. 54, pl. I, fig. I-3; Wilson, Proc. U. S. Nat. Mus., vol. 47 , p. 619 .

Host and record of specimens. - This species has been obtained from Argyrosomus artedi in Buffalo Harbor and Niagara River; from A. prognathus in Lake Ontario and Lake Michigan; from $A$. hoy in Lake Michigan; and from Coregonus clupeiformis in Lake Erie.

Achtheres micropteri Wright.

Achtheres micropteri Wright, Proc. Canadian Institute, n. S., vol. I, p. 249, pl. 2, fig. 1-II; Wilson, Proc. U. S. Nat. Mus., vol. 47 , p. 620 , pl. 34 .

Host and record of specimens. - Found by Wright on the smallmouth black bass near Toronto, Canada, and by the present author on the same host in the Kankakee River, Ind.; also found upon the largemouth black bass in the Kankakee River and at Lake Maxinkuckee, Ind., and at Constantia, N. Y.

Remarks.-On the gills of the largemouth bass this species, together with Ergasilus centrarchidarum, is often associated with glochidia of the Lampsilis group. Thus far none of these glochidia have been found on the gills of the smallmouth bass, but since both of the copepod parasites are found there it is reasonable to believe that future search will reveal some of the glochidia. At all events, the presence of the copepods shows that both bass are good subjects for artificial infection.

\section{Achtheres lacæ Krøyer.}

Achtheres lace Krфyer, Naturhistorisk Tidsskrift, 3 Raekke, 2 bd., p. 348, pl. 17, fig. 6; Wilson, Proc. U. S. Nat. Mus., vol. 47, p. 622, pl. 35 .

Host and record of specimens.-Found originally by Krøyer in the mouth of a North American perch, which he called "Perca laca," probably P. flavescens. Eight females were obtained from the gills of the striped bass, Roccus lineatus, in the Potomac River near Washington, D. C.

Remarks.-If Kroyer's specimens really came from $P$. flavescens, they were strictly fresh-water species; the striped bass, on the other hand, goes back and forth from fresh to salt water. This fact of course would make it of no use as a carrier of glochidia; none have ever been found upon its gills nor are they likely to be in the future.

Achtheres coregoni (S. I. Smith).

Lernaopoda coregoni Smith, Report U. S. Commissioner Fish and Fisheries for 1872-73, pt. 2, p. 664, pl. 3, fig. 17.

Achtheres coregoni Wilson, Proc. U. S. Nat. Mus., vol. 47, p. 623, pl. 36.

Host and record of specimens.-This species has been found upon the whitefish, Coregonus clupeiformis, in Lake Michigan, upon Argyrosomus artedi in the Niagara River, and upon A. hoyi in Iake Michigan. It has not yet been associated with any glochidium.

Achtheres ambloplitis Kellicott.

Achtheres ambloplitis Kellicott, Proc. American Soc. Microscopists, vol, 1, p. 56, pl. 3, fig. 6, 7; Wilson, Proc. U. S. Nat. Mus., vol. 47 , p. 626 .

Host and record of specimens.-Found on the red-eye, Ambloplites rupestris, at Lake Maxinkuckee, Ind., and in the Shiawassee River, Mich., and upon "redfish" at Big Payette Lake, Idaho.

Remarks. - This species is associated with Lampsilis glochidia on the gills of the red-eye, and its presence indicates that these fish are good hosts for artificial infection, as has been proved by actual experiments.

\section{LERNEIDA.}

Lernæocera variabilis, new species. (P1. LxxrI.)

Host and record of specimens.-Ten females were obtained from the scales and flesh of Lepomis pallidus in Whisky Slew, Fairport, Iowa, July Io, I912, and have received catalogue no. 47727, U. S. National Museum; fifteen females were obtained from the same host in the Mississippi River at Fairport, July 25, I9I2, and have received catalogue no. 47738, U. S. National Museum; six females from the same host in McPhersons Slew, Fairport, August 8, I9I2, catalogue no. 47739, U. S. National Museum; eight copepodid larvæ from the gill filaments of the short-nosed gar, Lepisosteus platostomus, in "Sunfish Lake," Fairport, July 24, r9r4, catalogue no. 47740, U. S. National Museum; five copepodid larvæ from gill filaments of the sauger, Stizostedion canadense, in Whisky Slew, Fairport, August I2, I9I4, catalogue no. 47741, U. S. National Museum; four copepodid larvæ from gill filaments of sauger in Dark 
Slew, Fairport, August $x_{4}$, rgr4, catalogue no. 47742, U. S. National Mifuseum; three copepodid larvæ from rill filaments of sauger in Lake Pepin, Mississippi River, August 2S, I9I4, catalogue no. 47743, U. S. National Museum. One or two copepodid larve were also obtained from the gills of the bullhead, Aneiurus melas, in "Sunfish Lake," August 20, I9I4; these were preserved and used for sectioning.

Spicific characters of fimale.-Body club-shaped, enlarged two or three diameters posteriorly; horns varying in number, size, and arrangement; usually they are four in number, short and very wide and strongly flattened dorso-ventrally, so that they become thin laminæ; the four are arranged in pairs, attached to the sides of the thorax, behind the head, the first pair just in front of the first swimming legs, the posterior pair just in front of the second legs; they are all about the same size, nearly as wide as long, and each is attached separately to the thorax and extends out nearly at right angles to the long axis of the body. Sometimes the two anterior homs are much larger than the posterior ones (fig. 90) and are turned forward like a large horseshoe, whose sides are parallel to the body axis; sometimes the two posterior homs are more or less fused into a single one, much smaller than the lateral anterior ones. Instead of being buried in the flesh these horns are often applied to the surface of the scales (fig. 92), with whose substance they apparently fuse quite solidiy, so as to furnish a secure attachment.

The body is segmented and the diameter posteriorly is three times that anteriorly; at the posterior end there is a small lateral tubercle on either side, ventral to the egg string, and a much larger median dorsil tubercle, the abdomen, which reaches far belind the lateral ones; the anal papilla are compara. tively large and jointed, and each carries three or four small setæ around the base in addition to the large terminal one.

The egg strings are narrow and elongate, less than a third the length and width of the body.

Head elliptical, a little longer than wide, without an anterior rostrum; first antennx three-jointed, the two basil joints considerably longer and wider than the terminal one, and all of them heavily armed with setr; second antenne two-jointed, the terminal joint half as long again as the basal and ending in a single large claw and a tuft of setre, the basal joint unarmed. Mandible a single slender curved claw mounted on a stout hemispherical base inside the lips; first maxilla a very much stouter claw, curved abruptly near the base and bluntly rounded at the tip; second maxilla armed with the usual two stout claws, also abruptly curved, but nearer the tip, which is much sharper than in the first maxilla.

Maxilliped comparatively large and stout, tipped with five strong curved claws, with a large blunt knob at their base and a medium-sized papilla on the inner margin, tipped with a single seta.

Color a dark creamy white.

Body length (excluding horns and egg strings), $6 \mathrm{~mm}$; greatest diameter, I mm. Length of egg strings, $3 \mathrm{~mm}$; diameter of same, $0.36 \mathrm{~mm}$.

(variabilis, variable, alluding to the size, number, and position of the cephalic homs.)

Remarks. - This species is chiefly characterized by the four flattened horms, which are entirely separated to their base and which are often attached to the surface of a scale instead of being buried in the flesh. The antennæ are also quite different from those of other species.

The discovery of the copepodid larvæ upon the gills of the sauger, the catfish, and the short-nosed gar serves to associate this species, and presumably the others also, with gill glochidia. These larvæ are very similar to an adult ergasilid but are smaller and of course without egg strings. They are very lively and loosen their hold (which is made by means of the curved claws on the second antennx) on the gill filament at the slightest provocation and dart around over the gills rapidly, taking a new hold somewhere else. For this reason they would probably offer more hindrance to the attachment of the mussel ghochidia than the sluseish ergasilids. At the same time the hindrance would be only temporary, since these are larve whose transformation only requires a brief period for its accomplishment, after which they leave the gills and fasten themselves elsewhere upon the body of a new host.

\section{Lernæocera tenuis, new species. (P1. LxxII, fig. 102-107.)}

Host and record of specimens.-A single female was taken from the side of the body of a sheepshead, Aplodinotus grunniens, at Fairport, July I6, I9I4; it becomes the type of the new species and has been given catalogue no. 47737 , U. S. National Museum.

Spccific characters of female.-Body long and slender with very little posterior enlargement; a single hom on either side of the head attached farther back than in other species, extending out at right angles to the body axis, and divided into two branches, the dorsal of which is much larger and nearly four times as long as the ventral; both branches are somewhat enlarged and bluntly rounded at the tip. 
Behind the head the body narrows for a short distance, then widens gradually, and there is no abrupt posterior enlargement. At the posterior end on either side above the base of the egg string is a small tubercle which is single and does not project much from the body; the dorsal median tubercle, the abdomen, is considerably larger than the lateral ones and terminates in the usual anal papillx. Each egg string is half the length of the body and four-fifths the width and tapers posteriorly to a narrow rounded point; the eggs are minute and there are about 150 in a string.

The head is circular in outline and a little wider than long; first antennæ three-jointed, joints diminishing a little in length and diameter from the base outward and heavily armed with setæ; second antennæ two-jointed, joints the same length, the basal one unarmed, the terminal one with the usual armature of stout curved claw and setæ. Second maxillæ as large as the maxillipeds, with stout terminal claws; maxillipeds short and thickset, each with four terminal claws, a small knob at their base and a minute process on the inner margin.

Color (preserved material), a grayish white.

Body length (excluding the homs and egg strings), $9.60 \mathrm{~mm}$.; greatest diameter, $0.60 \mathrm{~mm}$.; transverse length of both horns and head, $5.66 \mathrm{~mm}$. Length of egg strings, $4.25 \mathrm{~mm}$.

(tenuis, slender, alluding to the body as a whole.)

Remarks.-This species may be recognized by the fact that its horns stand out at right angles to the body axis and are cylindrical instead of flattened; its body is not enlarged posteriorly, and the egg strings are very long and slender. It does not appear to be common, since only a single specimen has thus far been found, and it is not known to be associated with any glochidium.

Lernæocera cruciata Le Sueur. (Pl. Lxxm, fig. I08, rog; Pl. LXXIV, fig. Iro.)

Lernococera cruciata Le Sueur, I824, Jour. Acad. Nat. Sci. Philadelphia, vol. 3, p. 286, pl. 2; Kellicott, 1880, Proc. Amer. Soc. Microscopists, vol. I, p. 64, pl. I, fig. I.

Host and record of specimens.-This species was originally reported by Le Sueur from the "rock bass, Cichla œnea" (Ambloplites rupestris) of Lake Erie. Kellicott's specimens were taken from "rock bass in the Shiawassee River, the Upper Saginaw, at Corunna, Mich., about 25 per cent of the fish being parasitized. * * * They are taken occasionally from the Niagara at Buffalo." (p. 68.) Gurley in his manuscript identified this species from the following hosts and localities: On rock bass from Lake Erie at Erie, Pa., June 21, 1894; from the Sandusky River at Fremont, Ohio; and from Fox Creek (tributary of the Detroit River) at Detroit, Mich., the latter on August 22, I894 (collector, Cloudsley Rutter). On the sunfish, Eupomotis gibbosus, from Cattaraugus Creek (tributary of Lake Erie) at Gowanda, N. Y., August 17, I893; from Elk Creek, Girard County, Pa., August 3, 1893; and from the Maumee River at Perrysburg, Ohio. On the redhorse, Moxostoma macrolepidotum duquesnei, from Maple River in Cass County, N. Dak. Gurley adds: "It should further be noted that the specimen in question is clearly $L$. cruciata and not Krøyer's $L$. catostomi, which also infests the redhorse."

Three lots of specimens were taken from the flesh along the sides of the body of the largemouth black bass, Micropterus salmoides; io females from Black Creek, N. C., catalogue no. 42306, U. S. National Museum; 7 females from Crooked S Slew, Fairport, Iowa, catalogue no. 47728, U. S. National Museum; 5 females from Scott, Lonoke County, Ark., catalogue no. 47729, U. S. National Museum.

Specific characters of female.-Body club-shaped, rather slender toward the head, gradually increasing in diameter posteriorly and terminating in a sudden enlargement at the posterior end. From either side of the cephalothorax extends a stout horn, chitinous in texture, which immediately divides into two conical branches, one of which is tumed forward and the other backward at varying angles. The basal portion of each horn is short and very broad, while the base of the posterior branck is often twice the diameter of the anterior. Body obscurely segmented, with a large double tubercle on either side at the posterior end, the median dorsal tubercle, the abdomen, being still larger though single and terminating in two small anal papillæ, each armed with two or three setæ. Egg strings conical, the base attached to the body, the pointed end free, one-third as wide as long; eggs small, not arranged in rows, about roo in each string.

Head one-quarter wider than long, with a narrow rostrum projecting from the center of the anterior margin; first antennæ four-jointed, the basal joint the shortest, the next joint the longest, all the joints heavily armed with setæ; second antennæ two-jointed, joints about the same length, the basal one unarmed, the terminal one ending in two curved claws, two long setæ and a shorter one, with four minute spines along the inner margin. 
First maxilla ending in a single claw; second maxilla with two claws of the same size; maxillipeds two-jointed, the basal jint unarmed, the terminal joint ending in five curved claws, at the base of which is a large rounded knob, and back of the knob on the inner margin a tiny process terminated by a single spine. The bases of the maxillipeds are so far behind the mouth tube that their tips do not quite reach the bases of the second maxillx.

Color of young specimens a uniform creamy white, turning more or less dark reddish brown with age, the tips and sometimes the entire branches of the cephalic horns dark brown, almost black.

Body length (excluding horns and egg strings), $8 \mathrm{~mm}$; greatest diameter, $0.70 \mathrm{~mm}$.; diameter of posterior enlargement, I.40 $\mathrm{mm}$. Length of egg strings, $2.10 \mathrm{~mm}$.; greatest diameter of same, $0.70 \mathrm{~mm}$.

(cruciata, torturing or tormenting.)

Remarks.-The parasite is usually attached nearer the head than the tail of the fish; the head, horns, and one-third of the body are buried in the flesh, usually beneath a scale or in the angle between two scales, and in such a way that the posterior two-thirds of the body points diagonally backward, and when the fish is in motion hangs close to the body of the latter. This species is associated with the glochidia of A nodonta corpulinta upon the largemouth black bass, and suggests that these external glochidia will subsequently be found also upon the other fish which serve as hosts for this Lernæoceran.

Lernæocera tortua Kellicott. (P1. LXXIV, fig. III-II3.)

Lernoocera tortua Kellicott, I83ı, Proc. Amer. Soc. Microscopists, vol. 2, p. 4I, I unnumbered plate.

Host and record of specimens.-Originally obtained by Kellicott from Grindstone Creek, a tributary of Lake Ontario, in July, I88o. Each I,ernæocera was deeply buried in a tumor caused by its presence just behind, or in the axilla of, a pectoral fin of "Ameiurus catus Gill." According to Dr. B. W. Evermann $A$. catus does not occur in Lake Ontario, the forms found there and usually referred to it being either melas or nebulosus, in this instance more probably the latter. Seven females were taken from A. nebulosus at Thomaston, Ga., by B. B. White and have been given catalogue no. I2030, U. S. National Museum. A single female was taken from Ictahurus furcatus at Fairport, Iowa, June 2, I9ro, and has received catalogue no. 47772 , U. S. National Museum.

Specific characters of the female.-Body straight and somewhat enlarged posteriorly; a lateral horn on either side of the cephalothorax, dichotomously branched, tuberculated, and standing out from the head at right angles to the body axis, so that the two homs are in the same straight line; a single dorsal horn, forked at the apex; all three horns strongly flattened anteroposteriorly and half as wide as long. In the Iowa specimen the horns are flattened, but the branches are much smaller and more slender than those of the Georgia specimens. Body sometimes obscurely segmented, with no lateral tubercles at the posterior end; the median dorsal tubercle or abdomen comparatively long and three-quarters of the diameter of the body; anal papillæ large and well armed with plumose setæ; egg strings moderately long (one-third the length of the body) and subcylindrical, tapering posteriorly.

Head ovate, considerably longer than wide; first antennæ four-jointed, the three distal joints about the same length, the proximal joint shorter; second antennæ three-jointed, the two distal joints about the same length, the proximal one much shorter; the terminal joint is enlarged and tipped with a long curved claw and several curved setæ; second maxillæ comparatively stout, each terminating in two large curved claws; maxillipeds rather short and stout, the terminal joint much narrower than the basal and ending in four or five slender claws, with a large knob at their base, but no papilla on the inner margin.

The two lateral cephalic horns are united across the front of the head and the ridge thus formed projects a long way's ventrally, owing to the anteroposterior flattening of the horns. On the ventral edge of the ridge, or a little removed from it on the posterior surface, is the first pair of swimming legs.

Color (preserved material), a rich reddish brown.

Body length (excluding horns and egg strings), II.25 mm.; greatest diameter, $0.75 \mathrm{~mm}$.; combined length of lateral horns, $3.90 \mathrm{~mm}$. Length of egg strings, $4 \mathrm{~mm}$.

Remarks. -The foregoing description and the accompanying figures agree fully with those given by Kellicott, except in the position of the fourth swimming legs (see p. III). In all the specimens obtained at 'Thomaston, Ga., the fourth legs are relatively much nearer the posterior end of the body than is represented by Kellicott, and there is no indication of another groove posterior to them or between them and the third pair. This species does not seem very widely distributed nor very abundant in any locality. While its hosts are common in the Mississippi River, only a single specimen of the parasite has thus far been found. 


\section{Lernæocera catostomi Krøyer.}

Lerncoocera catostomi Krøyer, 1863 , Naturhistorisk Tidsskrift, vol. 2, p. 321, pl. 18, fig. 4, a-e.

Host and record of specimens.-Two females were found by Kroyer upon a Moxostoma macrolepidotum duquesnii from the Mississippi River near St. Louis, Mo. None have been found since and the original specimens are probably lost, so that we are compelled to rely wholly upon Krøyer's description and figures, which may be summed up as follows:

Specific characters of female.--Body long and club-shaped, enlarged two or three diameters posteriorly; a short horn on either side of the cephalothorax, flattened anteroposteriorly and cleft at the tip; a similar median dorsal hom. Body segments indistinct; lateral tubercles at the posterior end poorly defined, median dorsal tubercle, the abdomen, but little longer and comparatively wide; egg strings narrow and elongate.

Head circular in outline, with a small broadly obtuse rostrum on the anterior border; first antennæ three-jointed and heavily armed with setæ; second antennæ two-jointed, the basal joint long and linear, the terminal joint small, oval, and armed with small setæe and spines; maxillipeds with a swollen basal joint and an oval terminal joint, tipped with four large and strong claws, gradually increasing in size, the outermost one as long as the segment; knob at the base of these claws small, papilla on the inner margin also small and tipped with a single spine.

Color, a uniform whitish yellow.

Body length (excluding horns and egg strings), 8 mm.; greatest diameter, I. 35 mm.

Remarks.-Neither of Krøyer's specimens had complete egg strings, so that their length can not be given, but the remnant left on one of the females indicated that they were long and narrow and the eggs were small. The species is readily distinguished from cruciata, which is found on the same host by the fact that it has three horns instead of two. From tortua it may be distinguished by the smaller size of the homs and the larger size of the abdomen and by the details of the antennæ and maxillipeds.

Lernæocera pomotidis Krøyer. (P1. LXXIV, fig. II4-II8.)

Lernaocere pomotidis Króyer, 1863, Naturhistorisk Tidsskrift, vol. 2, p. 323, pl. 15, fig. 5, a-h.

Host and record of specimens. - Six or seven females were originally obtained by Koryer from the gills of a "Pomotis" species near New Orleans. These are the types of the species and if extant are in the Royal Museum at Copenhagen. A single female was taken from the gill cavity of the bluegill, Lepomis pallidus, at Fairport, August 29, IgI4. It has received catalogue no. 47773, U. S. National Museum, and will serve as a surrogate type of the species if the original specimens are no longer in existence.

Specific characters of the species.-Body long and slender, only slightly enlarged posteriorly; a horn on either side of the cephalothorax, divided into two branches which are longer than those in cruciata, more slender, and more nearly parallel with the long axis of the body; each horn is two-fifths the entire length of the body and about the same diameter as the anterior portion of the thorax. Body obscurely segmented, the lateral tubercles at the posterior end large, distinct, and with a slight emargination at the center; the median dorsal tubercle, the abdomen, heart-shaped and but a trifle longer than the lateral ones; egg strings narrow and elongate.

Head circular in outline, about the same length and width and without any anterior rostrum; first antennæ four-jointed, the three terminal joints the same length and well armed with setre, the basal one shorter and unarmed; the terminal joint carries at its tip two curved claws, similar to those on the second antennæ; the latter are two-jointed, the terminal joint considerably longer than the basal and more slender; second maxillæ small with slender terminal claws; maxillipeds also small and slender, two-jointed, and terminating in three claws, with no knob at their base but with a large process on the inner margin, tipped with a tiny spine; these maxillipeds do not quite reach the posterior border of the maxillæ.

Color a uniform creamy white.

Total length (excluding horns and egg strings), ro.45 mm.; greatest diameter, $0.50 \mathrm{~mm}$.; length of horns, $4.20 \mathrm{~mm}$.

Remarks.-This is undoubtedly the same as Krøyer's specimens and shows that the species is not confined to the lower part of the river nor to one host, but is likely to be found elsewhere. The present host is one of the sunfishes and is closely related to Krøyer's "Pomotis sp., " and may even possibly be identical with it. The species may be distinguished by the long, sharp, and slender horns and by the fact that the body has almost no posterior enlargement. It is also worth special notice that it is found on the gills or in the gill cavity and not on the outside of the body. It is not well enough known as yet for it to be associated with any glochidium. 


\section{Lernæocera pectoralis Kellicott.}

Lernceocera pectoralis Kellicott, 1882, Proc. Amer. Soc. Microscopists, vol. 4, p. 77.

Host and record of specimens.-A dozen females were obtained from the red-finned shiner, Notropis cornutus, in the Shiawassee River at Corunna, Mich., in July and August, I88I. They were fastened to reddish lumps in the axils of the pectoral fins. None of these original specimens have been preserved and no others have heen obtained, so that Kellicott's description gives us all the knowledge we possess of the species; he published no figures.

Specific characters of fomale.-Body strongly bent and club-shaped; three horns on the cephalothorax, the two lateral ones three or four pronged, the dorsal one stout and forked at the apex. Body indistinctly segmented; the lateral tubercles at the posterior end small, the median dorsal tubercle, the abdomen, much longer and wider, and extending far over the bases of the ovisacs; the latter are short and club-shaped.

Total length, 7.50 mm.; width of horns, $1.70 \mathrm{~mm}$.

Remarks. - This species resembles $L$. tortua but is little more than half as long, the dorsal horn is forked, the egg strings are shorter and club-shaped, and the terminal setæ on the anal papillæ are not plumose.

None of these species of Lerncocera are as yet well enough known to enable us to establish their relations with the mussel glochidia. Whatever may be the relations of the adult fastened in the flesh of its host to the mussel glochidia on the fins, it is reasonably certain that the copepodid larvæ of the various species of Lernceocera are much more closely related to the glochidia on the gills. Before we can understand this relation thoroughly, there must be considerable more research and observation on the genus.

To facilitate the distinctions between the different species, the following table may be presented; in it the entire length of the parasite is taken as roo units, and the distance of the four pairs of swimming legs from the anterior border of the head (excluding the horns) is given in percentages of 100 .

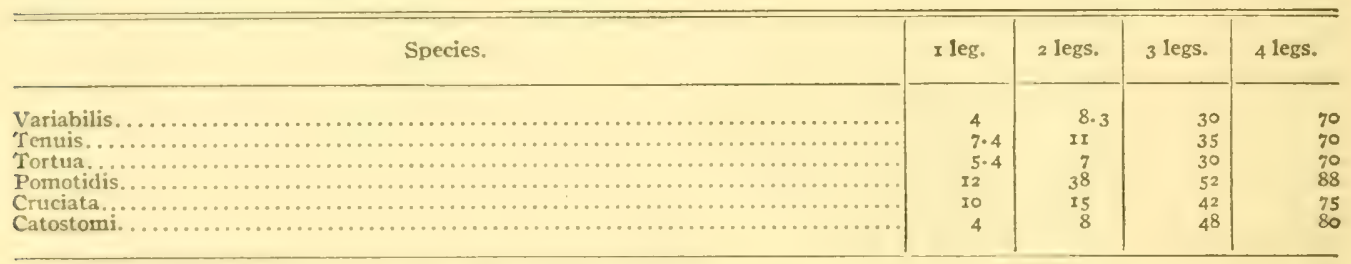

It is almost certain that the absolute distances vary in the same species with the development of the individual; the older the parasite becomes the farther removed are the legs from the head; but the relative distance of the pairs one from another ought not to vary much, and it is these relative distances that are expressed in the above table.

The male does not develop beyond the fourth copepodid stage and never attaches itsclf to the flesh of a fish nor to the body of the female, but after the mating of the sexes the male dies. This makes it necessary to secure the male from the tow or from the gills of some fish prior to the mating, by no means an easy task; but these males and the copepodid stages of the females furnish the data which will eventually decide the validity of the various species, as well as their economic relations.

\section{GENERAL REMARKS.}

In a recent paper by Dr. W. A. Cunnington, which is a report on the parasitic Inocopepoda and forms part of the "Zoological Results of the Third Tanganyika Expedition," "he says: "It is clear that whaterer may be the case for marine fishes, the fishes 
of fresh water are relatively seldom the prey of parasitic Eucopepoda under natural conditions" (p. 828'. And he adds: "A study of the literature of the subject confirms our conclusion."

His judgment is based upon the results of this African expedition, during which he says very large numbers of fish were examined, but only two of them were found infested with eucopepods.

While such a conclusion seems inevitable from the data he has given, it must be understood as applying to Africa, and perhaps to that portion covered by these Tanganyika expeditions and not to the world at large. There has been very little work done on the parasites of fresh-water fishes, as has been already shown (p. 333), and no one can say what the future holds in store. It is possible that other portions of Africa are richer in these parasites, and it is certain that the results of the present investigation are not essentially inferior to those obtained from salt-water fishes. It has already been stated (p. 34I) that a fish's efficiency as a host may be measured either by the number of any single parasite it harbors or by the variety of species. If we are comparing fresh-water fish with salt-water fish, or the fish from one region in the world with those from another region, we should take into account both the number and the variety. In variety of forms the salt-water fish considerably surpass those from fresh water, but in number of specimens the latter sometimes surpass the former. The present author never has obtained any salt-water fish that could compare with the two crappies in numbers of parasites. Furthermore, in the variety of species found upon any single kind of fish the fresh-water fish present an average fairly comparable with those from salt water. Three and four from the same fish are the general rule rather than the exception. (See table, p. 338.)

And if we were to include the mussel glochidia and all other kinds of gill parasites with the copepods, the salt-water fish would be hard pushed for a victory. Not many salt-water fish can compare with the crappie ( $P$. anmularis), which harbors i 3 species of glochidia, 3 species of copepods, and 3 species of trematode ectoparasites, I 9 in all; or with the sheepshead, which acts as the host of I I species of glochidia, 2 species of trematodes, and two of copepods, 15 in all; or with the sauger, upon which have been found 6 species of glochidia, 2 species of trematodes, and + species of copepods, 12 in all. And it must be remembered that these are all natural infestations, which have occurred under perfectly normal conditions. When we come to the abnormal conditions which are favorable to the copepod parasites, then their numbers increase to such a degree that they cause serious epidemics in the breeding ponds and often kill off large numbers of the fish; and since it is fresh-water fish only that are bred in this way it follows that this sort of damage is confined to them and does not occur amongst salt-water fish.

The facts presented in the present paper open up a very fascinating chapter in the book of copepod parasitology, and one that bids fair to become far-reaching in its practical relations; but it must be remembered that we have as yet scarcely made a beginning, and that a vast amount of work is still to be done before we can reach a final solution of the problems. From the facts here presented, however, it would seem as if fresh water presented fully as rich a field to the parasitologist as can be found in the ocean. 


\title{
EXPLANATION OF PLATES.
}

\author{
Plate LX.
}

Female of Argulus canadensis.

Fig. I. Dorsal view.

Frg. 2. Respiratory areas.

Fig. 3. First and second antennx.

Fig. 4. Chitin ribs supporting the margin of the sucking disks.
FIG. 5. Maxilliped.

FIG. 6. Basal joints of fourth leg.

\section{PLATE LXI.}

Females of Argulus flavescens and A. mississippiensis.

Frg. 7. Dorsal view of $A$. flavescens.

Fig. 8. Respiratory areas.

Fig. 9. First and second antennæ.

Frg. ro. Chitin ribs supporting the margin of the sucking disk.

FIG. Ir. Maxilliped.
FiG. 12. Basal joints of fourth swimming leg.

Fig. I3. Chitin ribs of sucking disk of A. mississippiensis.

FIG. I4. Maxilliped.

Fig. 15. Second, third, and fourth swimming legs of male.

\section{Plate IXII.}

Male and female of $A$. lepidostei and male of $A$. mississippiensis.

FIG. I6. Dorsal view of male of $A$. lepidostei.

Fig. 17. Third leg of male, showing accessory sexual apparatus.

FIG. I8. Chitin ribs supporting margin of sucking disk.
FIG. 19. Maxilliped of female.

Fig. 20. Chitin ribs supporting sucking disk of A. stizostethii.

Fig. 2 1. Dorsal view of male of A. mississippiensis.

\section{Plate LXIII.}

Male and female of Argulus mississippiensis.

Fig. 22. Dorsal view of female.

Fig. 23. Respiratory areas.

FIG. 24. First and second antennx.

FIG. 25-27. Second, third, and fourth legs of male, showing accessory sexual apparatus.

\section{Plate LXIV.}

Male and female of Argulus lepidostei.

Fig. 28. Dorsal view of female.

FIG. 29. Respiratory areas.

FIG. 30. First and second antennæ.

FIG. 3x, 32. Second and fourth legs of male, show ing accessory sexual apparatus.

\section{PLATE LXV.}

Newly hatched larva of Argulus lepidostei.

Fig. 33. Dorsal view.

Fig. 34. First antenna.

Fig. 35. Second antenna.

Fig. 36. Mouth tube and first maxilla.
Fig. 37. Second maxilla.

FIG. 38. Maxilliped.

FIG. 39. First swimming leg. 


\section{Plate IXXVI.}

Females of Ergasilus lanceolatus, elongatus, and megaceros.

Firg. 40. Dorsal view of E. lanceolatus.

Fig. 4I. Mouth parts.

Fig. 42. Second antenna.

FIG. 43-46. First, second, third, and fourth swimming legs.
FIG. 47. Side view of E. elongatus.

Fig. 48. Mouth parts.

FIG. 49. Mouth parts of E. megaceros.

Plate LXVII.

Female of Ergasilus nigritus.

FIG. 50. Dorsal view.

FIG. 5I. Second antenna.

Fig. 52. Mouth parts.
FiG. 53-56. First, second, third, and fourth swimming legs.

\section{Plate LXViII.}

Females of Ergasilus megaceros and E. elongatus.

Fig. 57. Dorsal view of $E$. megaceros.

Fig. 58-6r. First, second, third, and fourth swimming legs.
Fig. 62. Dorsal view of E. elongatus.

Fig. 63-66. First, second, third, and fourth swimming legs.

\section{PLATE LXIX.}

Female of Ergasilus elegans.

Fig. 67. Dorsal view.

Fig. 68. Second antenna.

Fig. 69. Mouth parts.

FIGS. 70-73. First, second, third, and fourth swimming legs.

Fig. 74. Nauplius larva of E. ccruleus.

Plate LXX.

Female of Salmincola californiensis.

FIG. 75. Dorsal view.

FIG. 76. Side view.

FIG. 77. Top of head.

FIG. 78. Second antenna, side view.
Fig. 79. Ventral view of same.

FIG. 80. Mandible.

FIG. 8I. First maxilla.

FIG. 82. Maxilliped.

\section{Plate LXXI.}

Male and first copepodid larva of Achtheres pimelodi.

FIG. 83. Side view of male,

Fig. 84. First and second antennæ.

Fig. 85. First maxilla.

Fig. 86. Dorsal view of larva.
FIG. 87. Mouth parts: $m d$, mandible; $m x$, first maxilla.

FIG. 88. Second maxilla.

FIG. 89. Maxilliped.

\section{PLATE LXXII.}

Female of Lernceocera variabilis.

FIG. 90. Ventral view.

Fig. 9I. Head and anterior thorax, much enlarged. Fig. 92. Scale of fish host, showing mode of attachment.

Fig. 93. First antenna.

Fig. 94. Second antenna.
FIG. 95. Mouth parts: $m d$, mandible; $m x^{1}$, first maxilla; $m x^{2}$, second maxilla; $l b$, labium.

FIG. 96. Maxilliped.

Fig. 97-100. First, second, third, and fourth swimming legs.

Fig. Ior. Anal lamina. 
Plate LXXIII.

Females of Lerncoocera tenuis and L. cruciata.

FIG. I02. Ventral view of $L$. tenuis.

FIG. I03. First and second antennx.

Figs. 105-107. First, second, and third swimming legs.

FIG. I04. Mouth parts: $m x^{2}$, second maxillæ; $m x p$, FIG. I08. Ventral view of $L$. cruciata. maxillipeds.

Fig. Iog. Dorsal view of same.

Plate LXXIV.

Females of Lerncocera tortua, cruciata, and pomotidis.

FIG. IIo. Mouth parts and antennæ of L. cruciata: $a n^{1}$, first antenna; $a n^{2}$, second antenna; $m x^{1}$, first maxilla; $m x^{2}$, second maxilla; $m x p$, maxilliped.

Frg. IIr. Ventral view of L. tortua.

Fig. II2. Dorsal view of horns.

FIG. II3. Antenne and mouth parts, lettering as in figure $\mathbf{I} 10$.
Fig. II4. Ventral view of $L$. pomotidis.

FIG. II5. Dorsal view of posterior end of body.

Fig. II6. First antenna.

FiG. Ir7. Second antenna.

FIG. II8. Maxilliped. 
Bull. U. S. B. F., I9I4.

PLATE LX.
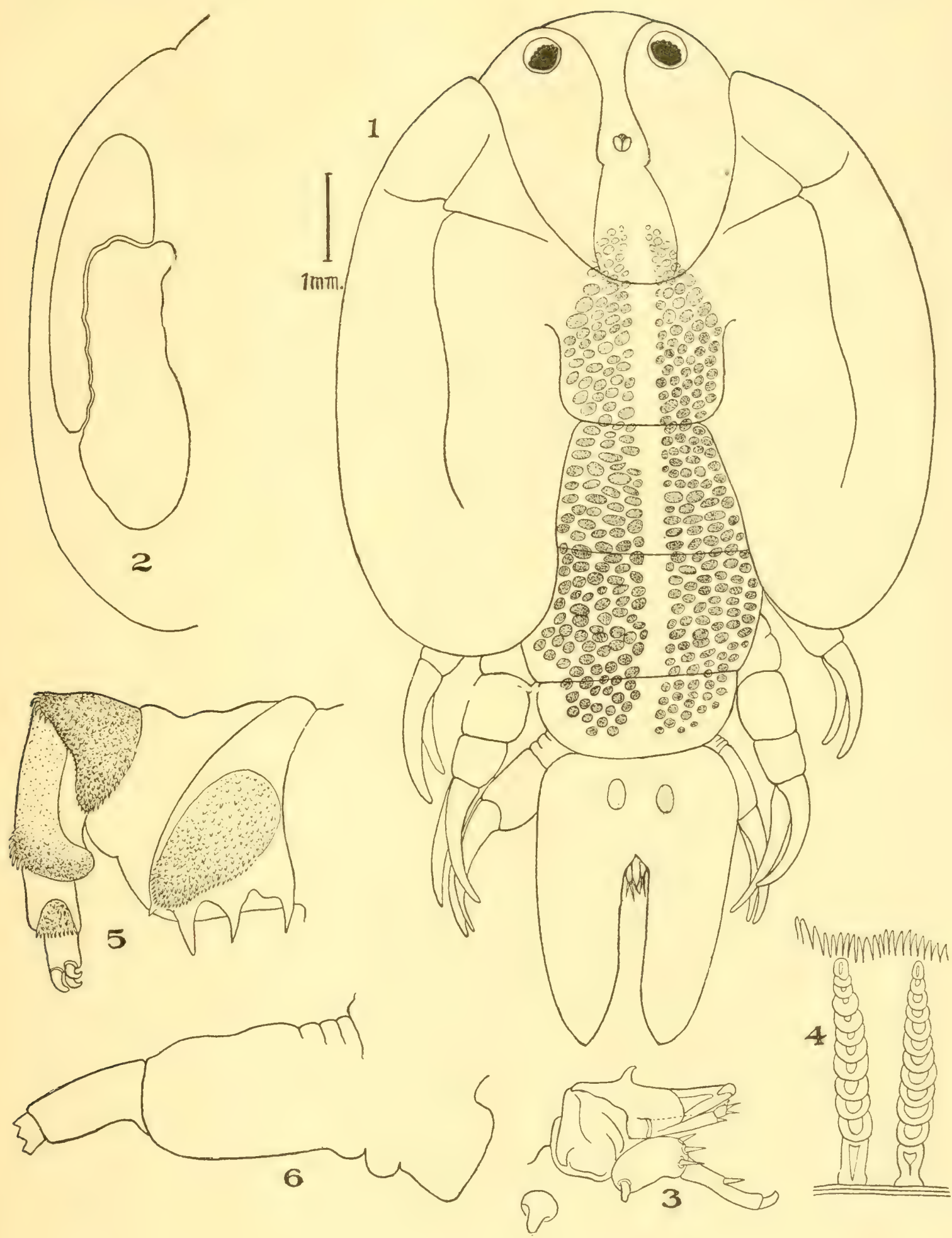


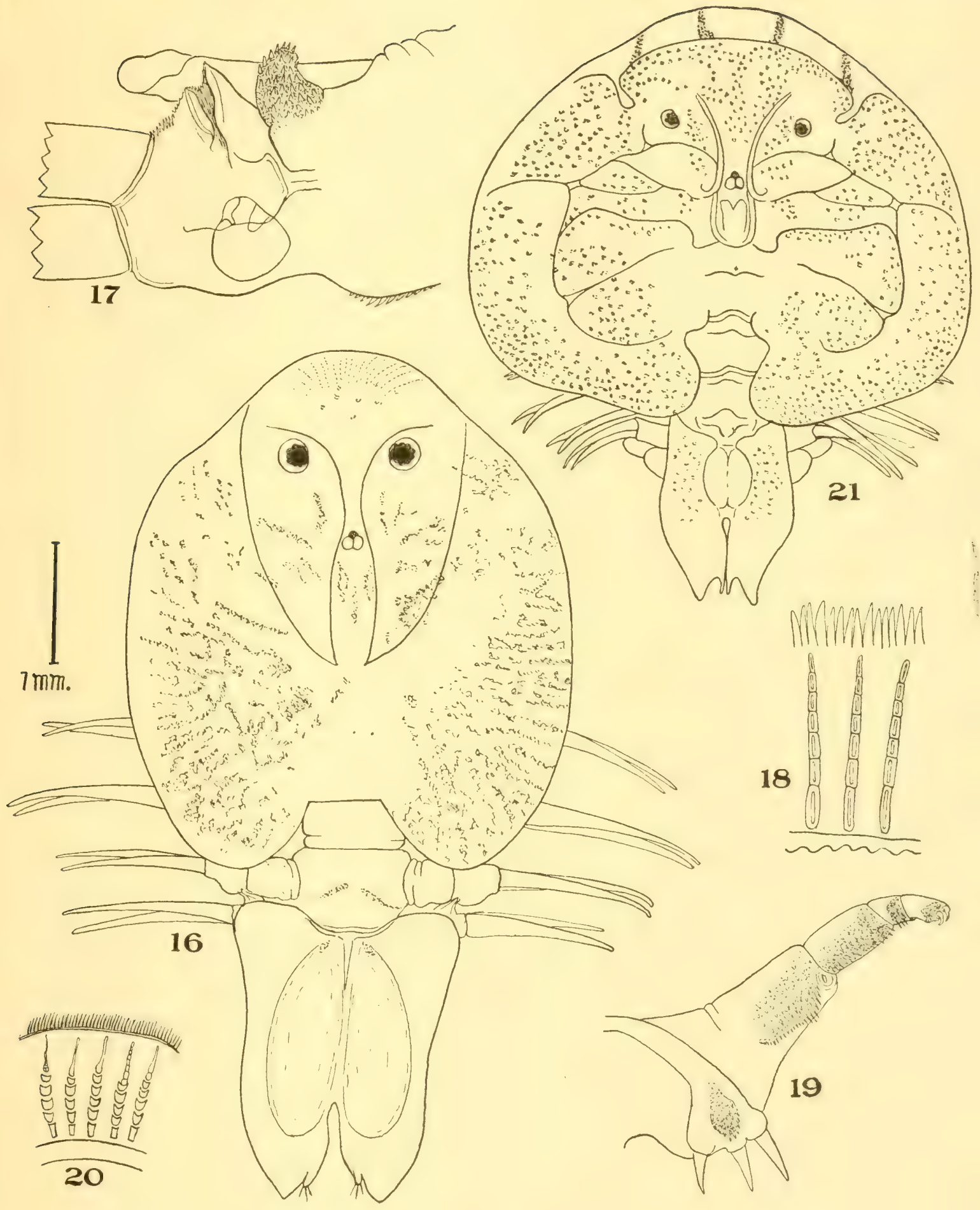



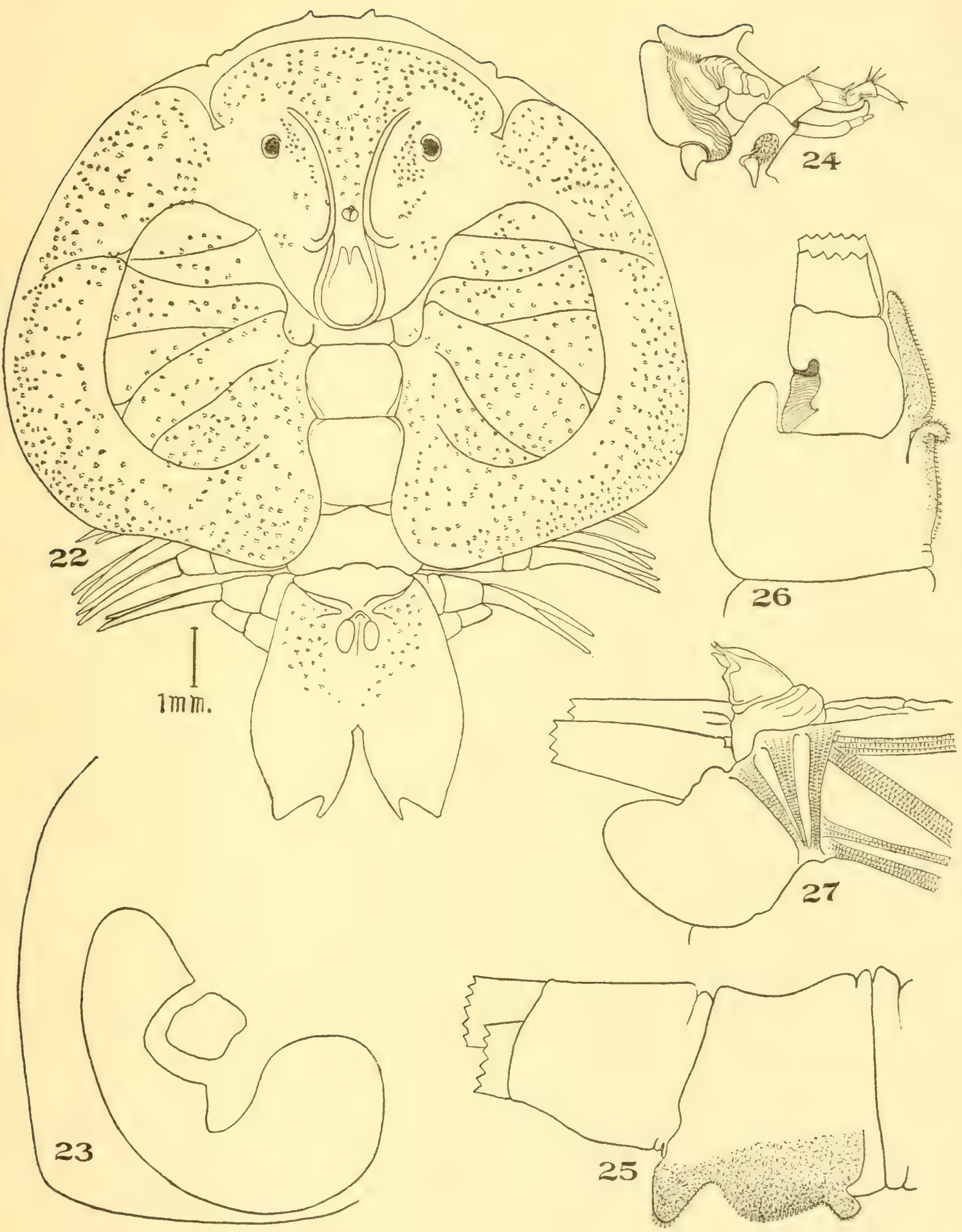





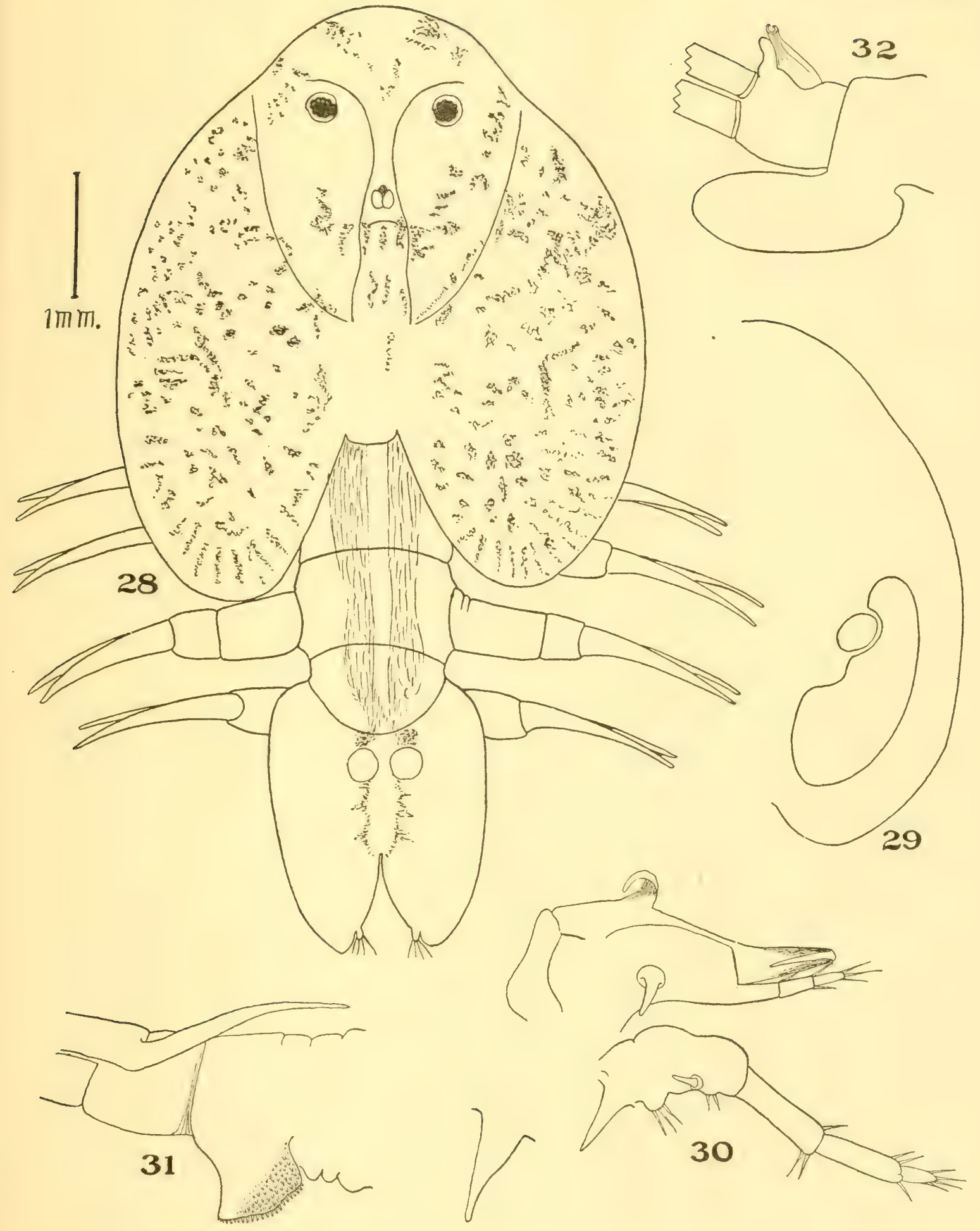





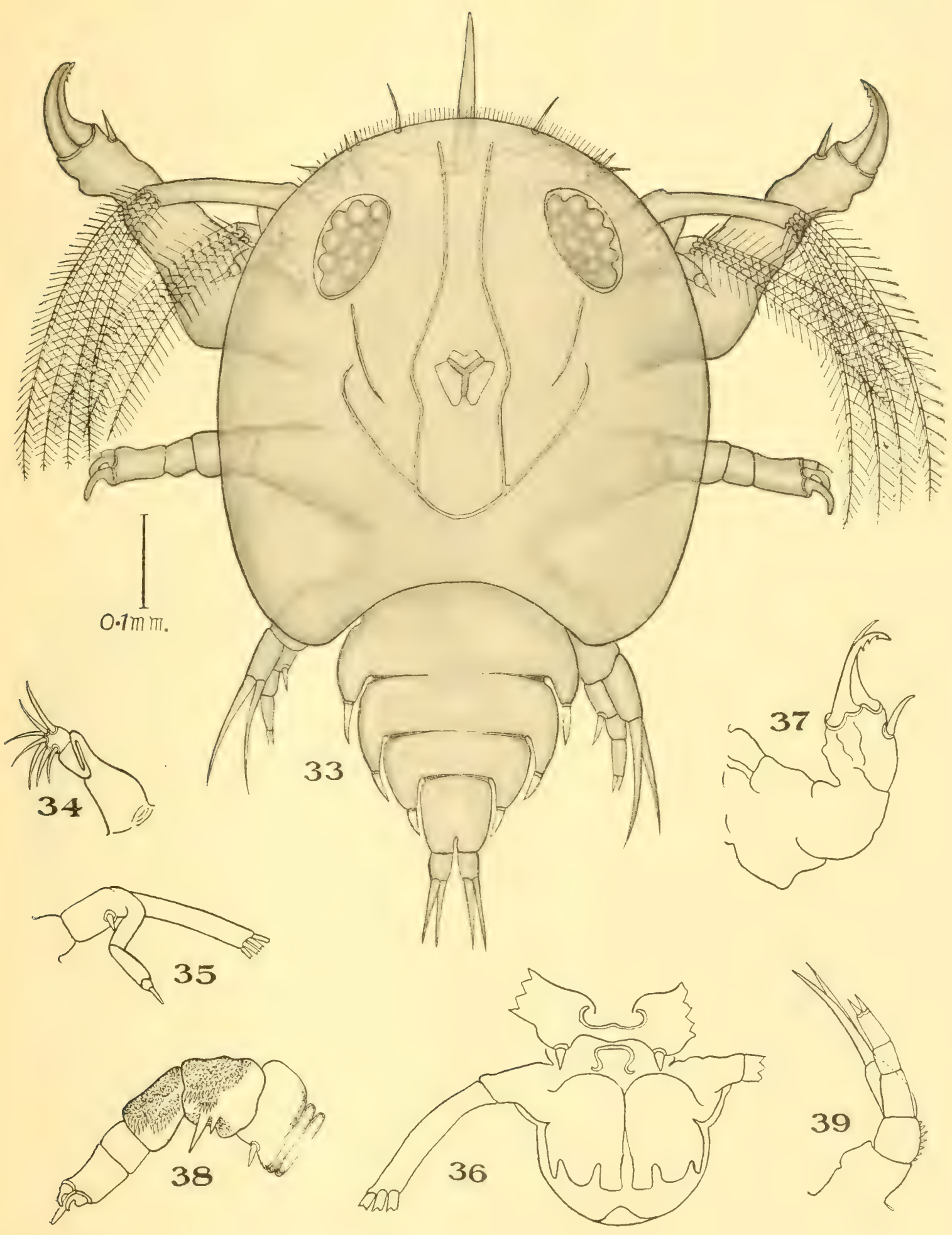





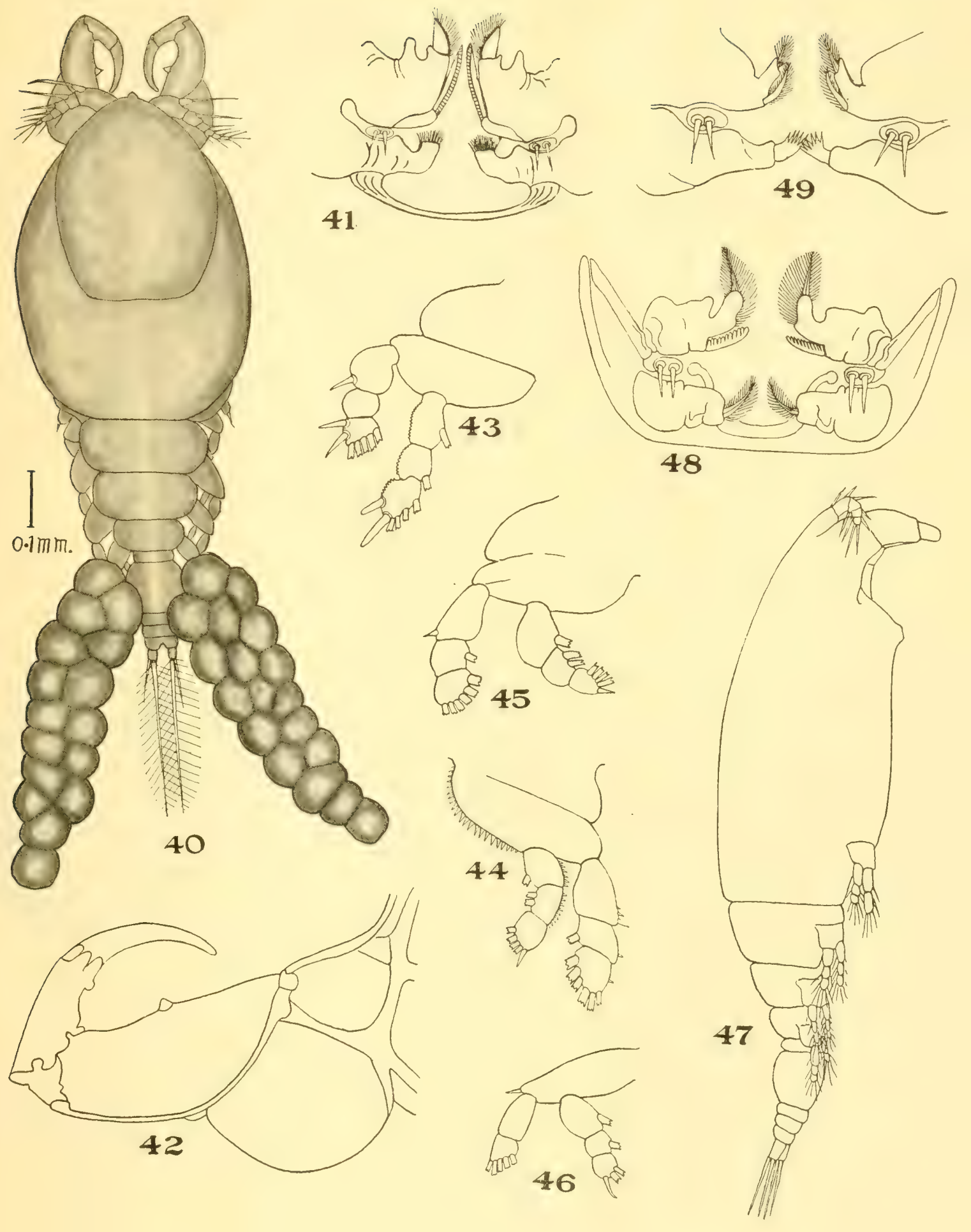



BULL. U. S. B. F., I9I4.

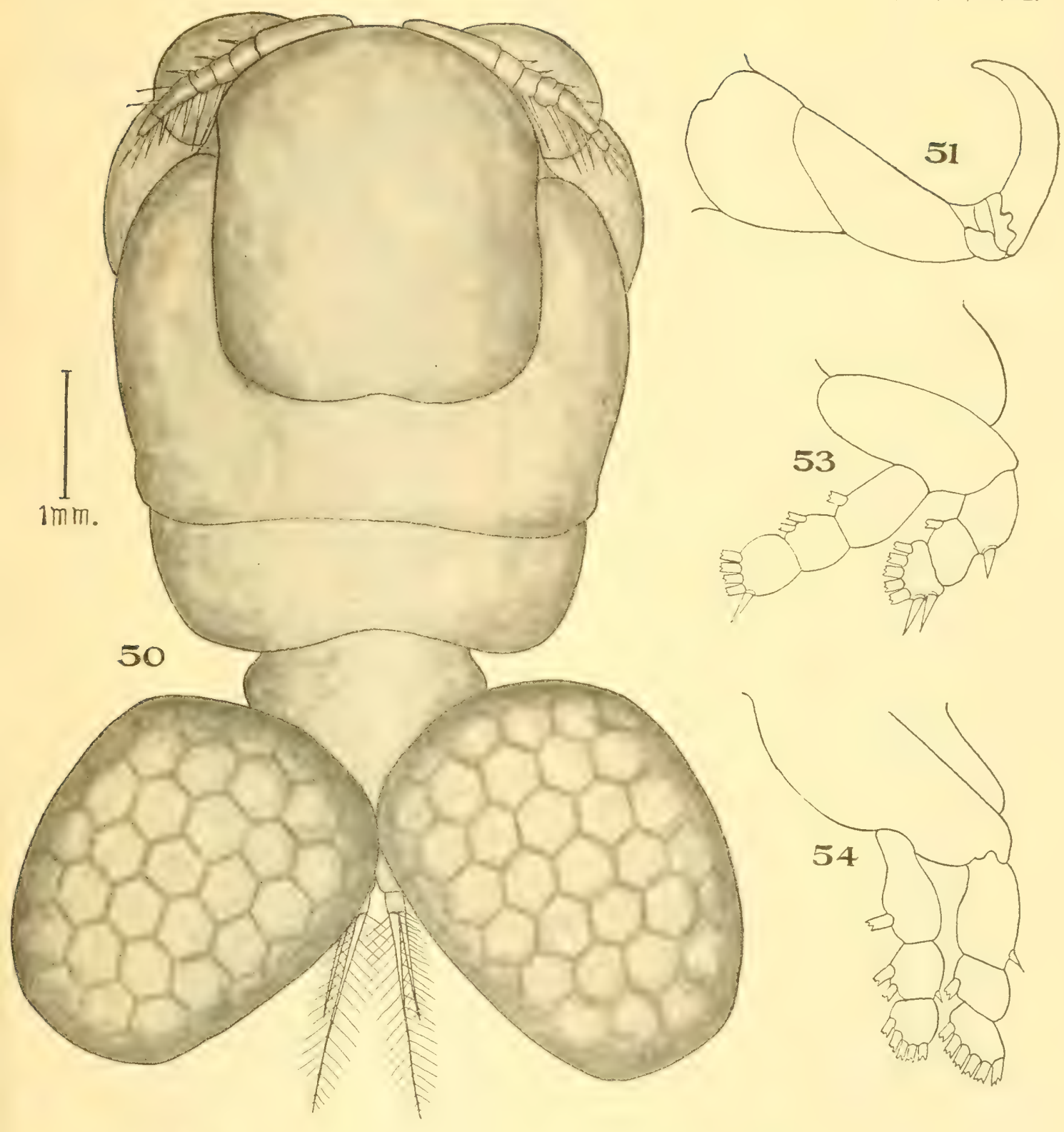

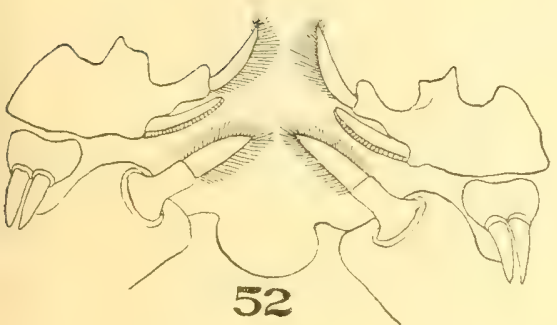
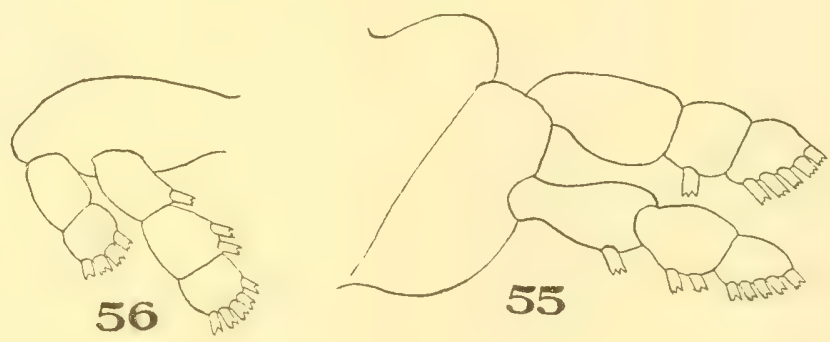

BUl... U. S. B F., I9I4.

Plate I, XVIII.
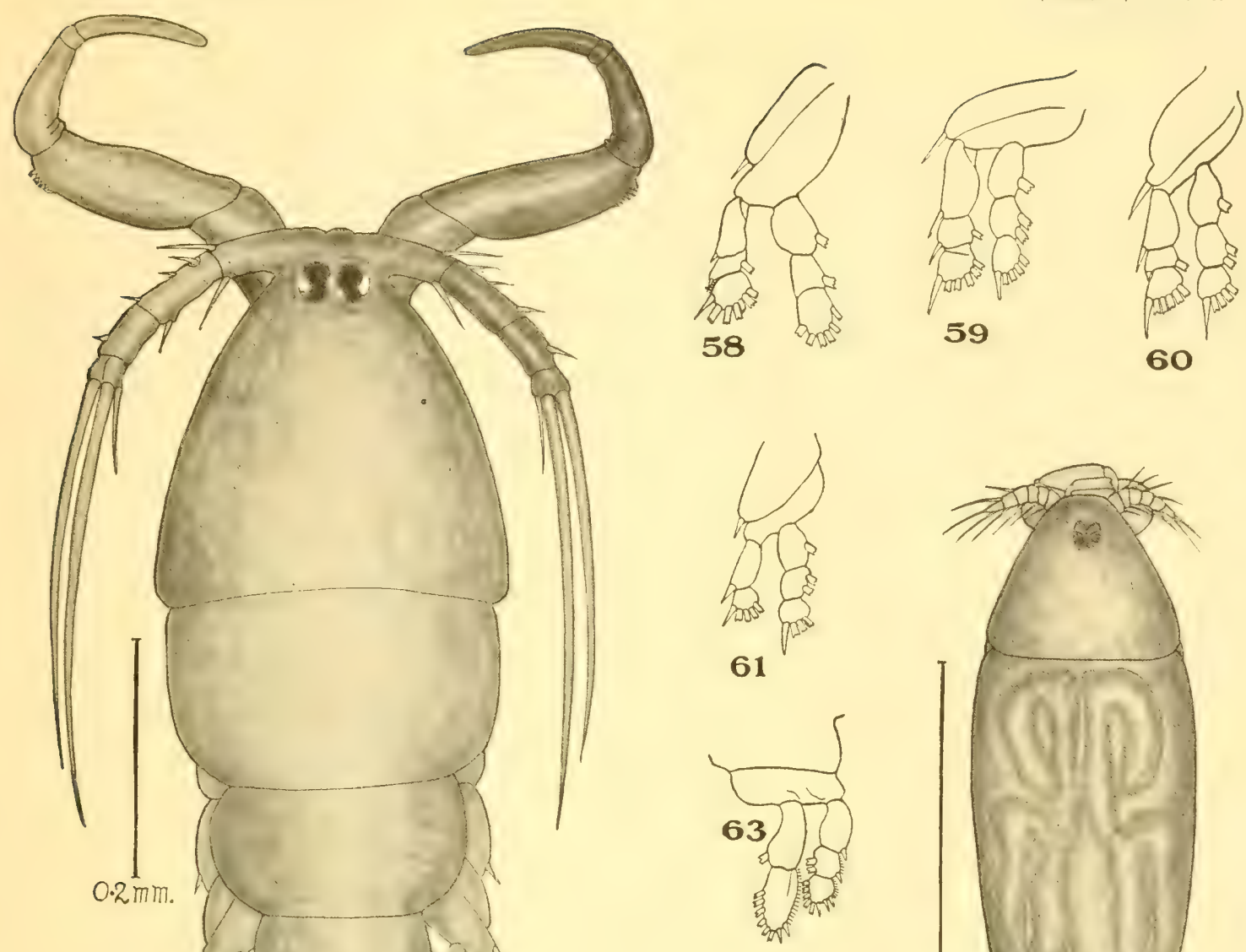

$0.2 \mathrm{~mm}$.

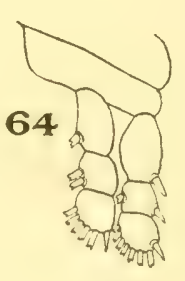

$0.5 \mathrm{~mm}$.
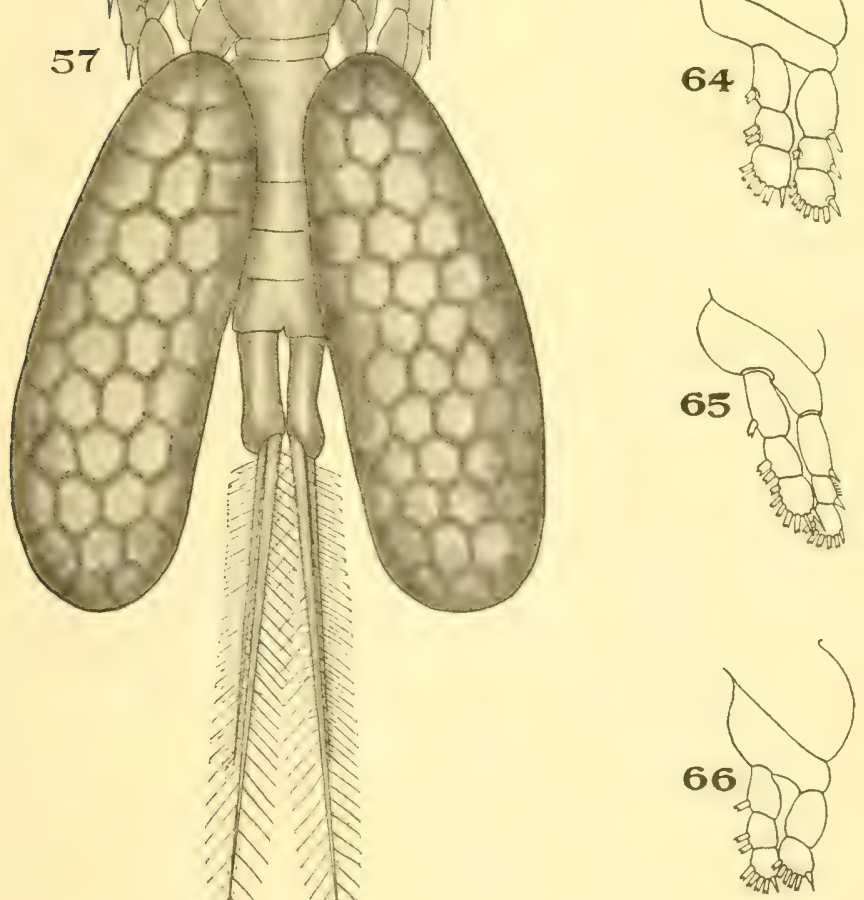


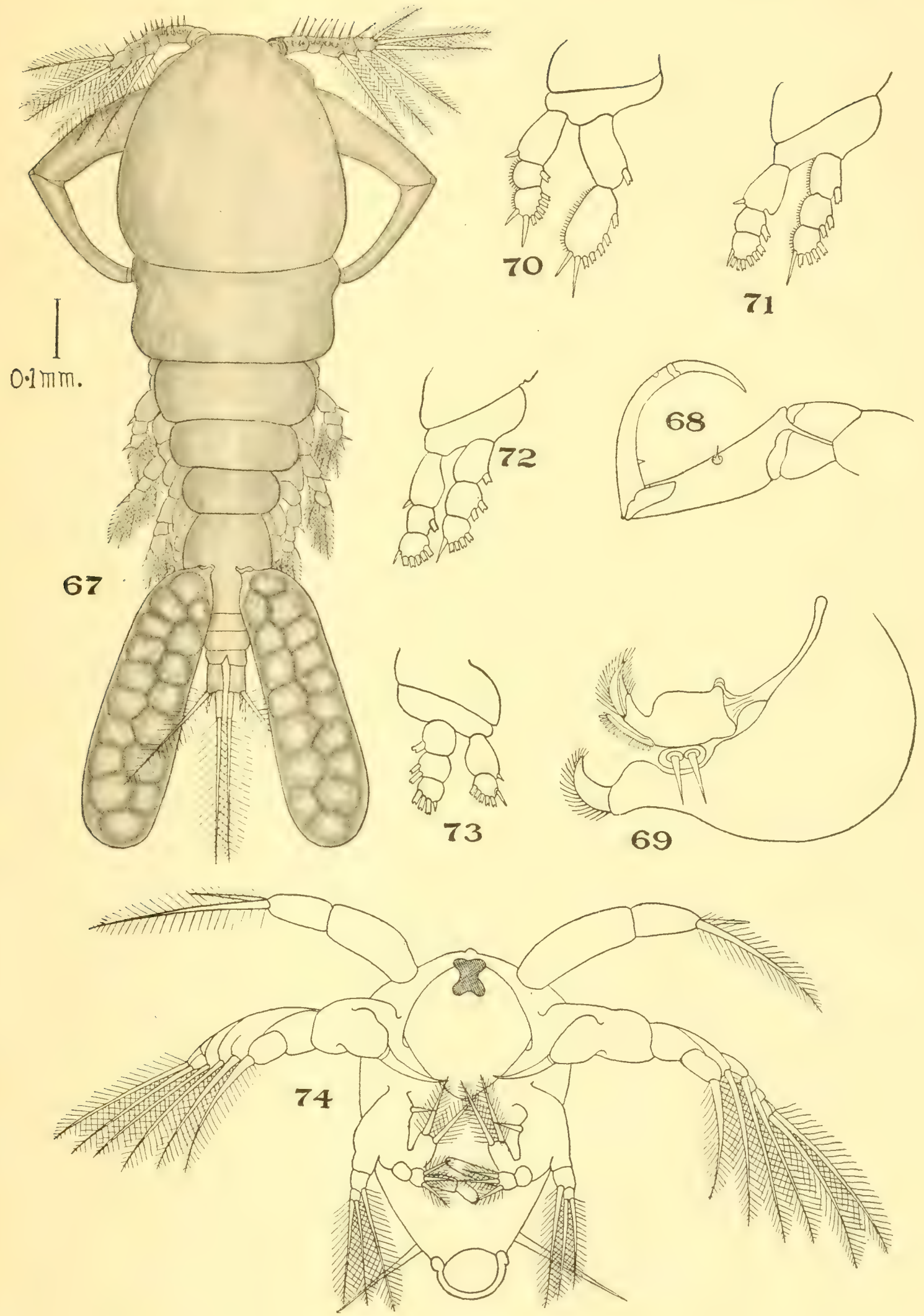



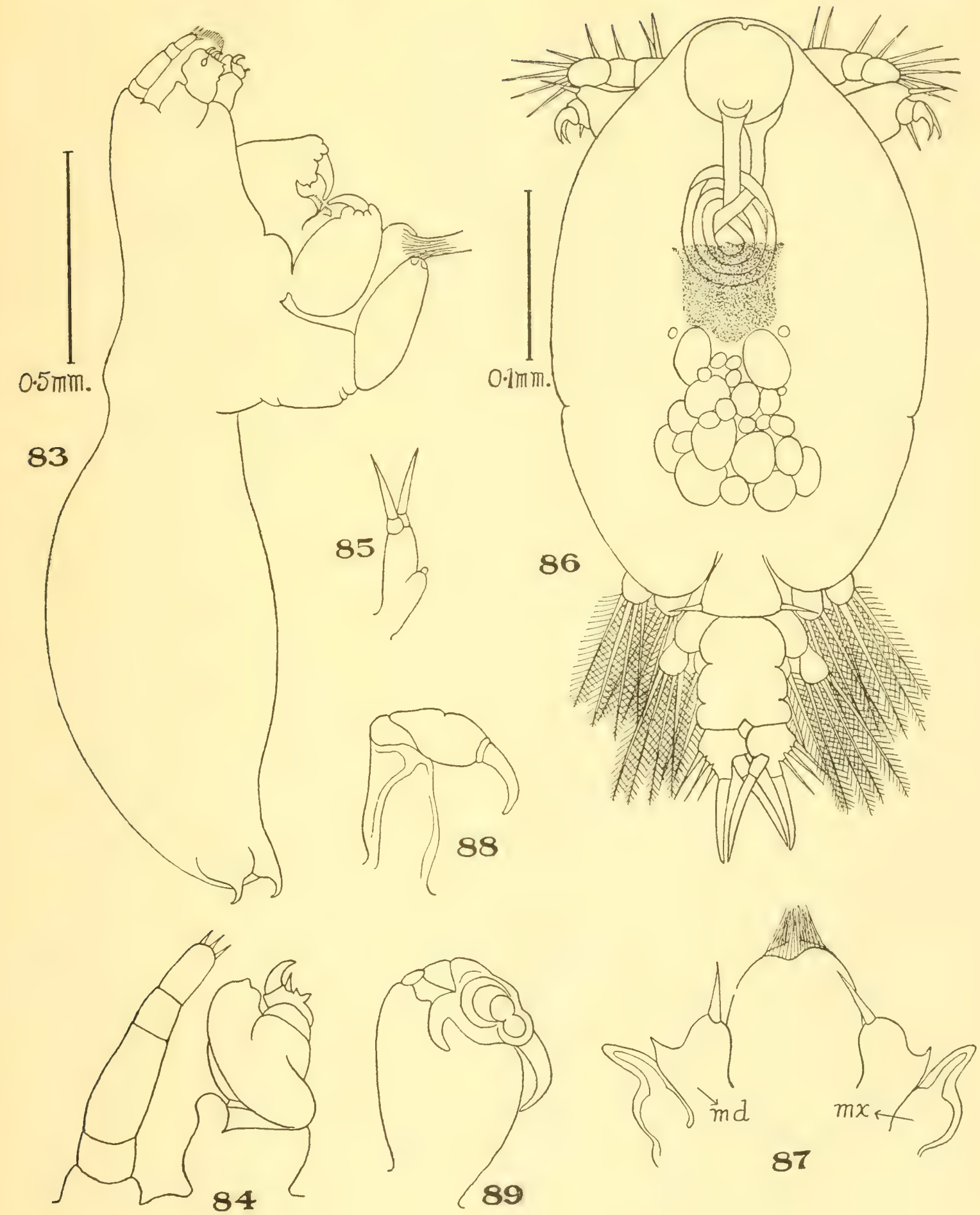

BULL. U. S. B. F., I9I4.
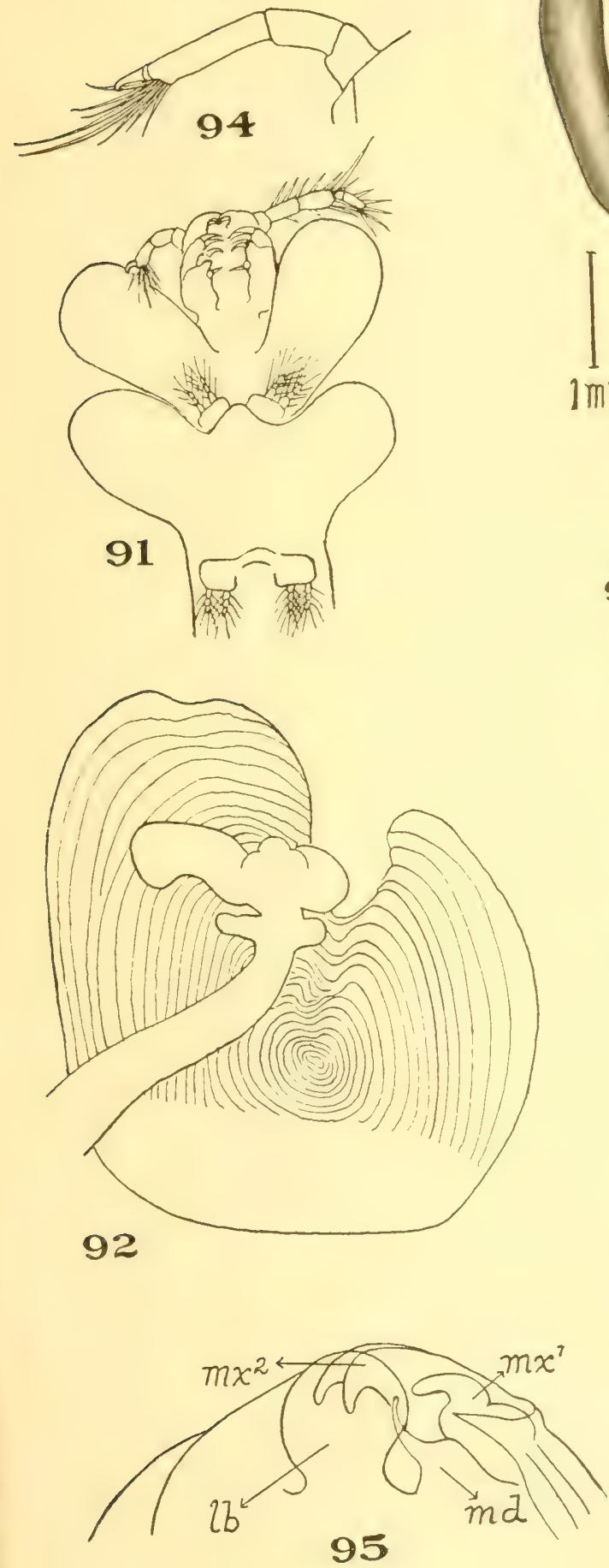

PIATE LXXII.

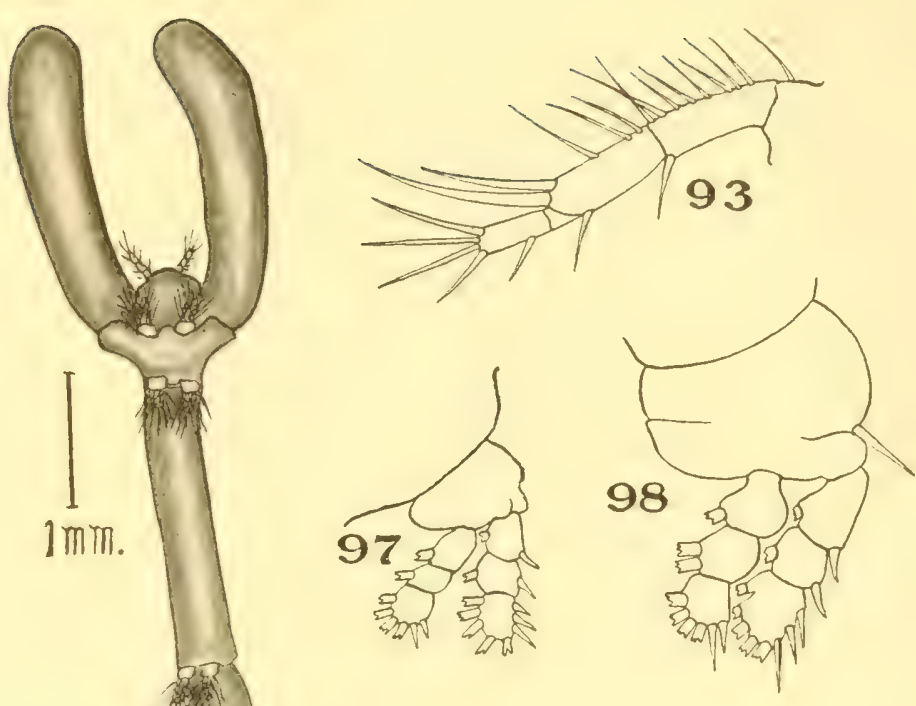

90

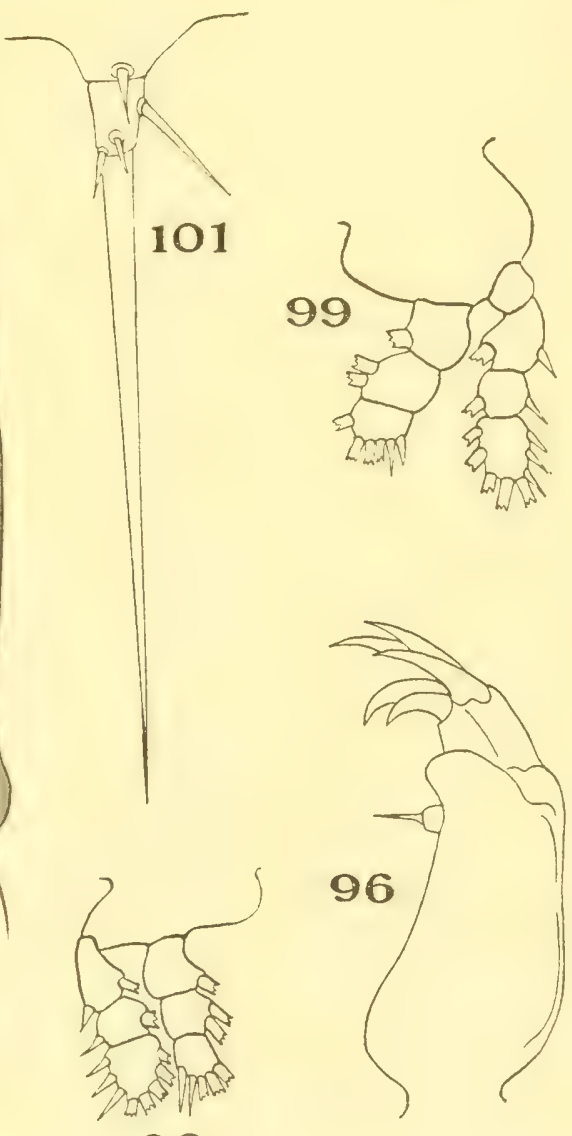




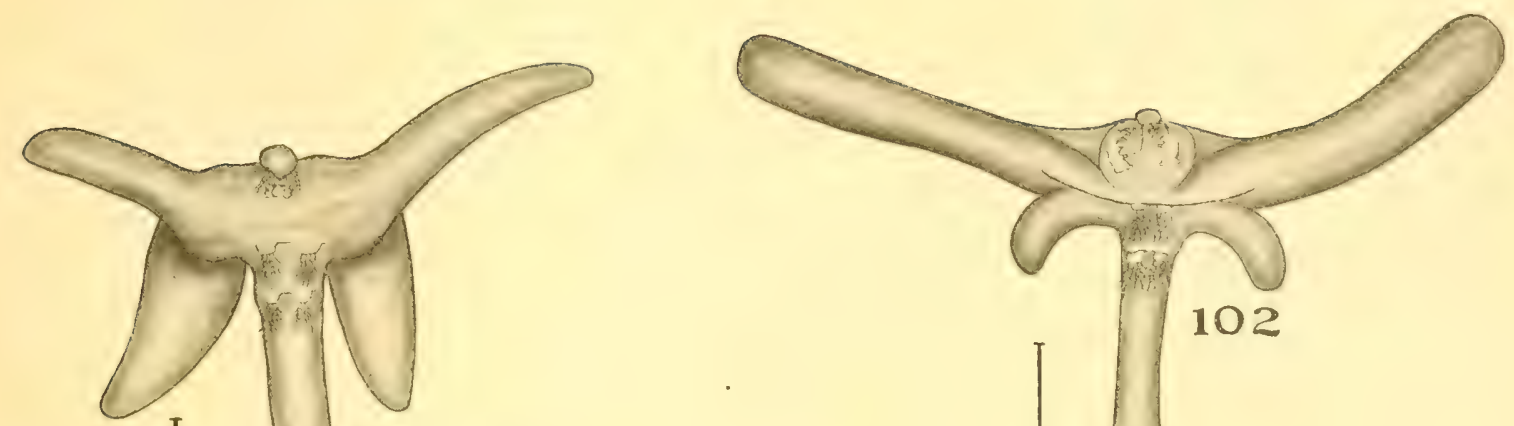

102

$I$

$1 \mathrm{~mm}$.

\section{8}

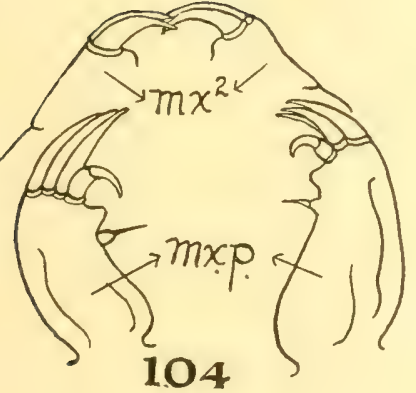

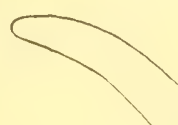

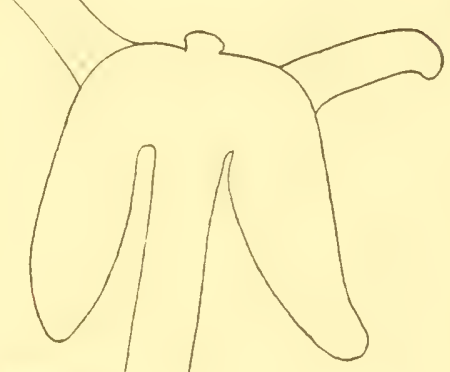

109

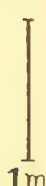

$1 \mathrm{~mm}$

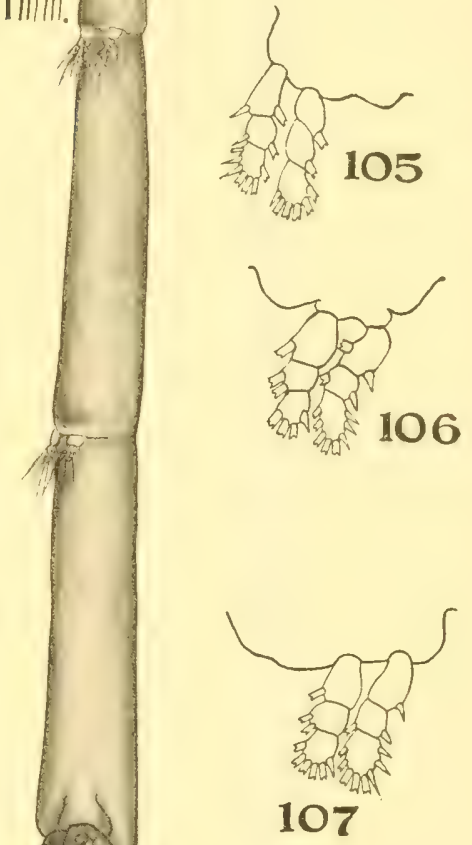

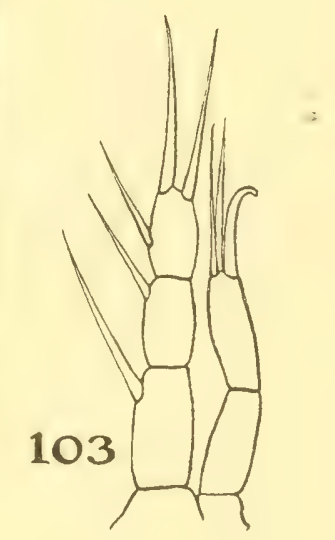





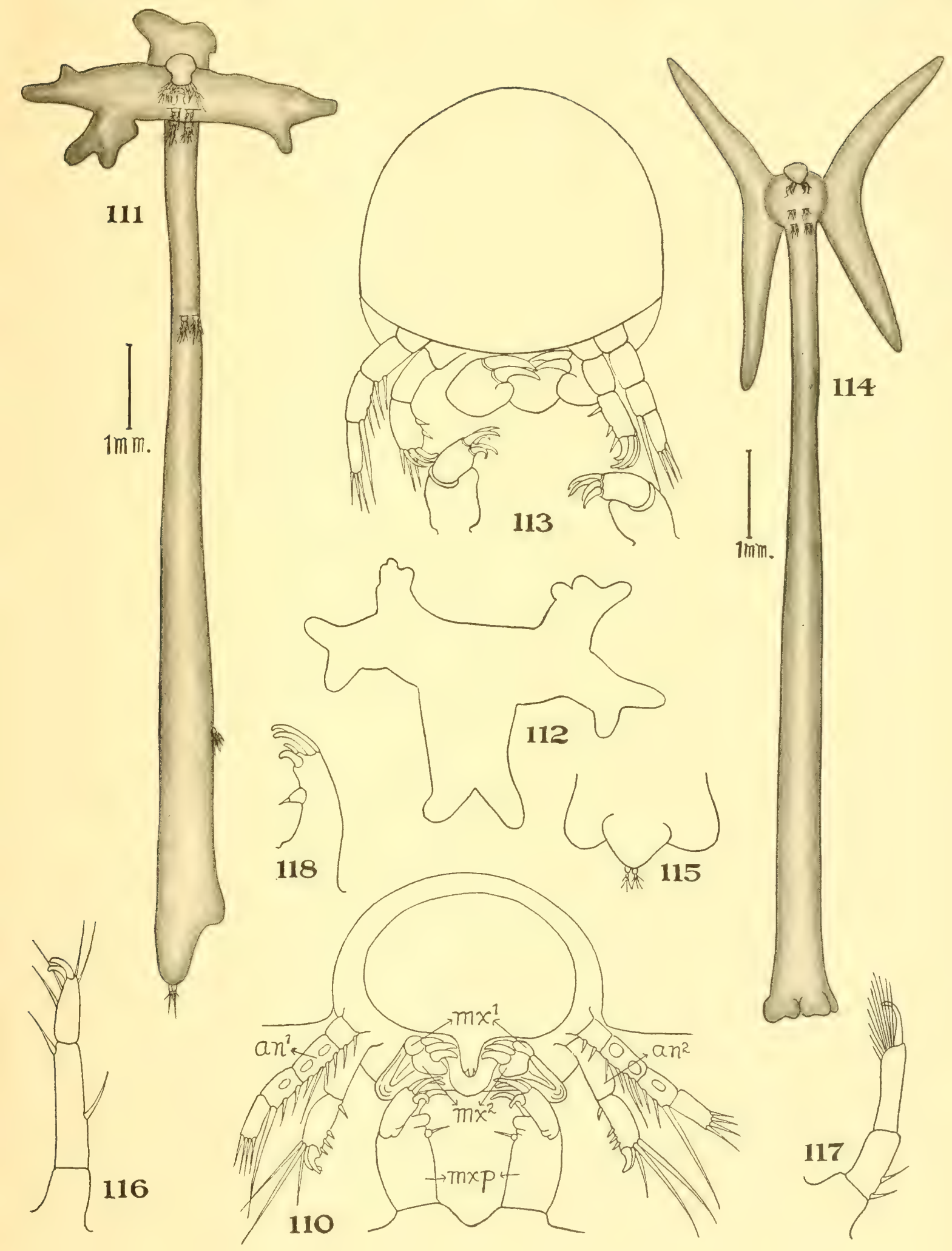







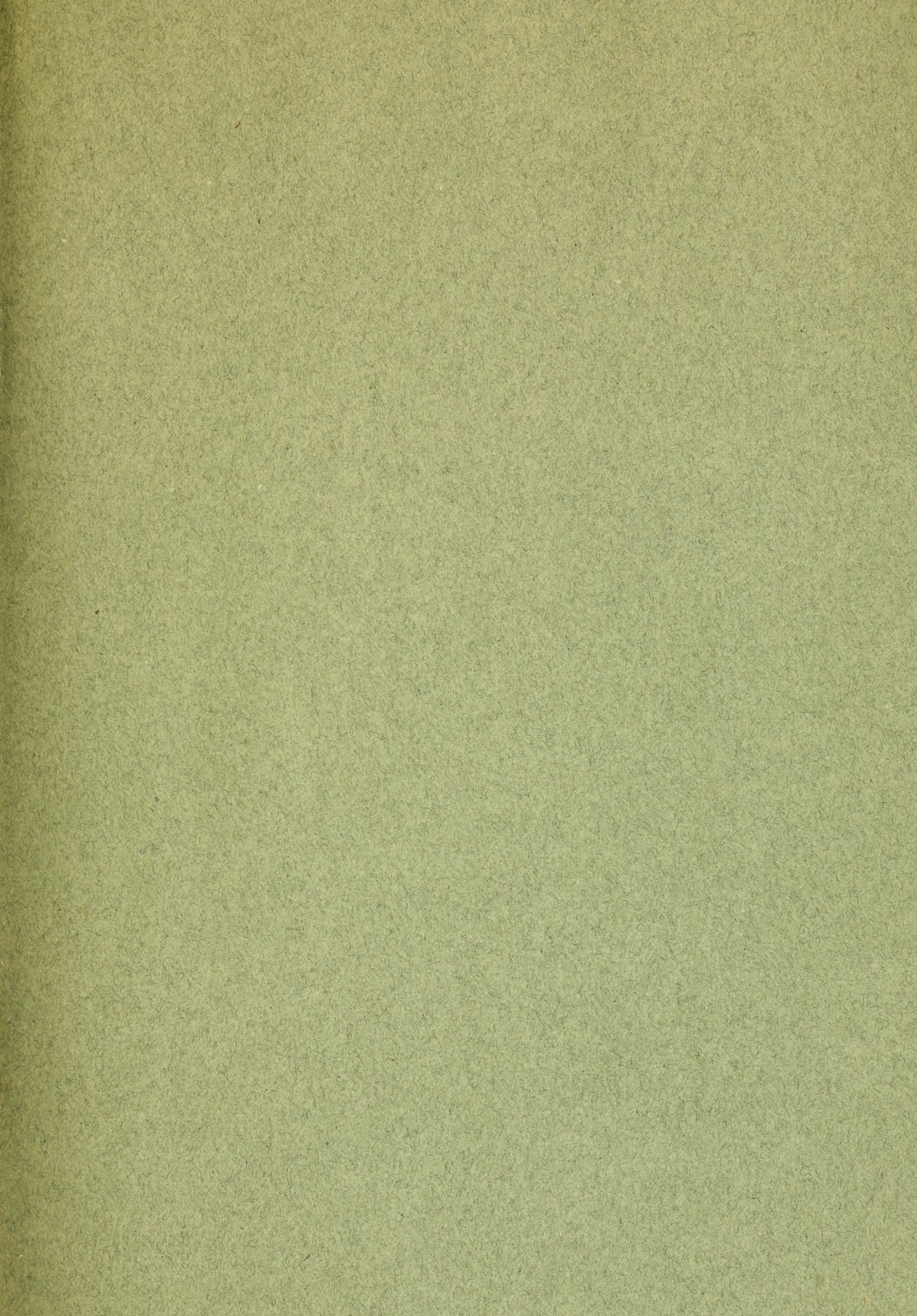

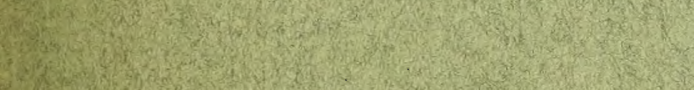


LIBRARY OF CONGRESS

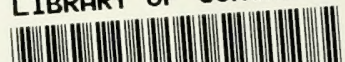

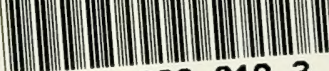
$0 \quad 003 \quad 8280193$ 